\title{
VERBOVSZKI Sándor \\ Az eljárás lezárult, ítélet nélkül. \\ A dr. CSATÁRY László Lajos ügy \\ jogi és kriminalisztikai anomáliái a dokumentumok tükrében.
}

\author{
„A meglelt igazság, légyen bár orcája sokféle, \\ soha nem csalfa, de mindig csak egy."1
}

4 944. III. 19-én a német hadsereg megszállta Magyarországot, és néhány héttel később Kassán keresztül megkezdődött a magyarországi zsidóság deportálása, amely érintette a Kassa környéki zsidók jelentős részét is. 1944. X. 15-én SZÁLASI Ferenc átvette a hatalmat Magyarországon, és ezzel újult erővel folytatódott a zsidók, a politikailag másként gondolkodók üldözése és likvidálása.

Ennek, a Kassán 1941. VII. 1945. I. 18-ig terjedő időszaknak tette kényszerü főszereplőjévé dr. CSATÁRY László Lajost ${ }^{2}$ a Magyar Királyi Rendőrség segédfogalmazóját, a jeruzsálemi Simon WIESENTHAL Center (SWC) vezetője.

Dr. CSATÁRY László Lajos 1942 őszétől 1944. október végéig szolgált a Magyar Királyi Rendőrség személyi állományában segédfogalmazóként az 1938-as első bécsi döntés alapján a Magyar Királysághoz csatolt felvidéki Kassán a rendőrkapitányság kötelékében. (A polgári magyar állam idöszakában Magyarországon úgynevezett kontinentális típusú rendvédelmi modell müködött, amelynek az volt a lényege, hogy a rend fenntartása alapvetöen két testület müködésén nyugodott a rendörség és a csendörség szervezetén. Emellett a rendvédelmi modellben részt vettek még a pénzügyőrség, a határőrség, a testörségek, a koronaőrség, a képviselöházi örség és a mai fogalmaink szerinti büntetés-végrehajtás, amelyet a korabeli terminológia szerint fegyöröknek hívtak. ${ }^{3} 1919$ októberéig kétféle rendörség müködött Magyarországon az állami rendörségek, a fövárosi rendörség 1872-töl, majd 1881-töl, ${ }^{4}$ a határrendörség 1906tól ${ }^{5}$ és a fiumei állami rendörség 1916 -tól, ${ }^{6}$ valamint az önkormányzati rendörségek. A törvényhatósági jogú és a rendezett tanácsú városok önálló rendőri szervezetekkel rendelkeztek. ${ }^{7}$ A magyar rendörségeket pedig 1919-ben - a fövárosi rendörség mintájára - államositották. ${ }^{8} \mathrm{Vi}$ déken a rendet pedig a Magyar Királyi Csendörség tartotta fenn. ${ }^{9}$ A polgári magyar állam idöszakában a rendet kétféle típusú rendvédelmi testület tartotta fenn: a katonailag szervezett fegyveres örtestület és a polgári fegyveres örtestület. A katonailag szervezett fegyveres örtestület tagjai személyükben katonának minösültek, függetlenül attól, hogy a testületük mely tárca irányitása alá tartozott. Mint katonák a honvédelmi tárca kompetenciájába tartoztak ugyan, a testületük irányitását, ellátását azonban az illetékes szaktárca valósitotta meg. A katonailag szervezett fegyveres örtestületek személyi állományának tagjait a katonákra általában vonatkozó jogok illették meg, illetve kötelezettségek terhelték. E testületeken belüli belsö függelmi viszonyok katonaiak voltak. Ezzel szemben a polgári fegyveres örtestületek személyi állományának a függelmi viszonyai nem katonaiak, hanem hivatalnokiak voltak. A személyi állomány az alá a tárca alá tartozott, amely a testületet irányitotta és annak anyagi ellátását is biztositotta. A polgári fegyveres örtestületek személyi állományainak tagjai személyükben nem minösültek katonának, így rájuk a katonák általános jogosultságai és kötelezettségei sem vonatkoztak. ${ }^{10} \mathrm{Az}$ önkormányzati és állami rendörségek, majd az államositott magyar rendörség is polgári fegyveres örtestület volt. A magyarországi rendörségek államositásáig valamennyi rendörség önálló rangrendszerrel rendelkezett, 1919-ben azonban a fóvárosi rendörség rangrendszerét tették általánossá az új államositott magyar rendörségnél. ${ }^{11}$ Ezen testület neve Magyar Királyi Állami Rendörség volt, amelyet 1931-ben - szervezeti módositásokkal egybekötve - Magyar Királyi Rendörségre változtattak. ${ }^{12}$ 1944-ben a Magyar Királyi Rendörségnél - háborúra való tekintettel - bevezették a katonai rangokat. ${ }^{13}$ A magyarországi rendörségek, majd az államositott rendörség egyenruházata azonban sohasem volt azonos a honvédség, illetve a társ rendvédelmi testületek egyenruházatával, így a különbözö egyenruhát viselö személyeket nem lehetett összekeverni. a szerk.) (I.sz. melléklet)

Mivel a kassai rendőrkapitányságon ő beszélte anyanyelvi szinten a német nyelvet, dr. HoRVÁTH György, Kassa akkori vidéki rendőrfőkkapitány helyettese a tolmácsolással és a német parancsnoksággal történő összekötő tiszti feladattal bízta meg. Feladata a magyar rendőrség és a német egység vezetője közötti információk közvetítéséből állt, így mind a rendőrségen, mind a 
városban az ő neve vált ismertté, és ez által maradt meg sokak emlékezetében. Nevét a háborút követően Magyarországon a dr. HORVÁTH György volt kassai vidéki rendőrfőkapitány helyettes ellen lezajló népbírósági eljárásban ${ }^{14}$ is felhasználták. Szlovákiában pedig kollaboráció és fasiszta megszállás büncselekmény elkövetése miatt dr. CSATÁRY László Lajos, mint volt magyar kassai rendőrkapitány ellen indult népbírósági eljárás, ${ }^{15}$ melyet halálos ítéletével zártak le.

Ez a több mint 70 év távlataiba is visszanyúló nyomozás nem lehetett volna eredményes, ha a levéltárakban és közkönyvtárakban történő kutatásaim során az ott dolgozó vezetök és munkatársak a témában tartott konzultációkon az elhivatottságuknak köszönhetően egy-egy akadály felmerülésekor nem segítették volna továbblendíteni munkámat.

Köszönet illeti az Országos Széchényi Könyvtár, a Magyar Nemzeti Levéltár, Budapest Föváros Levéltára, a Hadtörténelmi Levéltár, a Pest Megyei Levéltár, a Veszprém Megyei Levéltár és Kassa Állami Levéltára minden olyan munkatársát, akik kutatómunkámat segítették.

Ezúton fejezem ki köszönetemet azoknak a Felvidéken élő magyaroknak, akik szakmai tudásuk révén a Kassai Állami Levéltárból származó szlovák nyelvủ periratok magyar nyelvre történő fordításában segítettek. Köszönet illeti továbbá az érintett kanadai hivatalok munkatársait, akik a Kanadai Szövetségi Bíróság (The Federal Court of Canada) által kezdeményezett és a Kanadai Királyi Szövetségi Rendőrség (Royal Canadian Mounted Police) által 1993 és 1997 között lefolytatott nemzetközi nyomozás során keletkezett „Ladislaus Csizsik-CSATARY” ügy dokumentációjához $^{16}$ segítettek hozzájutni és mindazokat, akik lefordításukban segítségemre voltak.

\section{Dr. CSATÁRY László Lajos Magyarországon és az ellene 2011 szeptemberében háborús büncselekmények elkövetése gyanúja miatt indított eljárás alapja}

Dr. CSATÁRY László Lajosban már az 1990-es évek elején felmerült a Magyarországra történő hazatelepülés gondolata. A Kanadában töltött negyvennyolc év során magyarországi kapcsolata nem sok volt, a hazai viszonyokat kevéssé ismerte, ezért tájékozódni próbált. 1997-ig több alkalommal is járt Magyarországon. Ügyvédet bízott meg azzal, hogy járjon utána, vissza tud-e térni Magyarországra, merül-e fel a hazatéréssel kapcsolatban valamilyen jogi, vagy más akadály. A kedvező választ megkapva 1997-ben az egyik kanadai nagyváros magyar konzulátusán jelezte hazatérési szándékát. Felvéve a magyar állampolgárságot, kanadai állampolgárságáról lemondva, magyar okmányok birtokában feleségével együtt még abban az évben Magyarországra települt.

Efraim ZuROFF, a jeruzsálemi Simon WIESENTHAL Center igazgatója 2012. IV. 14-én a „The Jerusalem Post” hasábjain hozta nyilvánosságra, hogy 2011 szeptemberében a magyar ügyészségen feljelentette a Budapesten élő dr. CSATÁRY László Lajos háborús bünöst, és aki ennek ellenére még mindig nincs börtönben.

2012. IV. 19-én Efraim ZUROFF ismét a „The Jerusalem Post”-ban jelentette be, hogy a magyar ügyészségen az általa 2011 szeptemberében feljelentett és Budapesten élö kilencvenöt éves dr. CSATÁRY László Lajosnak kulcsszerepe volt abban, hogy 1941 nyarán háromszáz zsidót Kassáról az ukrajnai Kamenyec-Podolszkij-ba deportáltak, ahol szinte mindegyiküket meggyilkolták.

A központ szerint dr. CSATÁRY László Lajos 1944 tavaszán Kassán rendörparancsnokként részt vett több mint 15000 zsidó Auschwitzba deportálásának megszervezésében is. Efraim ZUROFF bejelentése szerint dr. CSATÁRY László Lajos a Simon WIESENTHAL Center által legkeresettebb tíz háborús bủnös nevét tartalmazó kőrözési listájának első helyén állt.

Figyelemre méltó tény azonban, hogy dr. CSATÁRY László Lajos neve 2012 elött, —KÉPÍRÓ Sándor 2011-ben hasonló ügyben indított és bíróság által történő felmentéséig — egyetlen Simon WIESENTHAL Center listán sem szerepelt.

2012. VII. 18-án a Budai Központi Kerületi Bíróság végzésse ${ }^{17}$ dr. CSATÁRY László Lajos budapesti lakost a Büntetőtörvénykönyv Btk. 165.§-ba ütköző egyéb háborús büncselekmény elkövetése megalapozott gyanúja miatt házi őrizetbe helyezte. ${ }^{18}$

A Büntető törvénykönyv 165 . §-a szerint az egyéb háborús bűntettekröl külön jogszabály rendelkezett. ${ }^{19}$ „Az Ideiglenes Nemzetgyülés által 1944. december 21-22. napjain a Debrecenben adott felhatalmazás alapján az ideiglenes nemzeti kormány attól a szükségtöl vezettetve, hogy mindazok, akik a magyar népet ért történelmi katasztrófa okozói, illetve részesei voltak, mielöbb elnyerjék büntetésüket, az esküdtbiróságnak törvényhozás útján való visszaállitásáig a népbiráskodás megvalósitása tárgyában a következőket rendeli: 
Általános rendelkezések

1. $\S$ A jelen rendeletben körülírt büncselekmények az esetben is büntethetök, ha a cselekmény a rendelet életbeléptekor már befejeztetett, s a cselekmény befejezésének időpontjában fennállott törvényes rendelkezések alapján az büntethetö nem volt. . . .

Különös rész

11. § Háborús bünös az:

5. aki a megszállott területek lakosságával vagy a hadifoglyokkal való bánás tekintetében a háborúra vonatkozó nemzetközi jogszabályokat súlyosan megsértette, vagy a visszacsatolt területek lakosságával a reábízott hatalommal visszaélve kegyetlenkedett, vagy aki általában akár belföldön, akár külföldön felbujtója, tettese vagy részese volt emberek törvénytelen kivégzésének vagy megkínzásának." 20

\section{A dr. CSATÁRY László Lajos ellen tett feljelentés}

Efraim ZuROFF 2011. IX. 21-én a Budapesti Nyomozó Ügyészségen feljelentést tett:

„A hamis vád és a hatóság félrevezetésének törvényes következményeire történt figyelmeztetést megérettem és tudomásul vettem. 2011. szeptember 8-án jutott a tudomásomra e-mail formájában, amelyböl értesültem, akkor még név nélkül, hogy náci háborús bünös él itt Magyarországon, Budapesten. Talán két-három nappal késöbb újabb e-mailt kaptam töle, miután megígértem neki, hogy névtelen marad, amelyben már arról tájékoztatott, hogy ezt a bizonyos személyt Csatáry Lászlónak hivják. Az e-mailekböl később derült ki az is számomra, hogy egy ismeretlen hölgyröl van szó. Ezt ö állitotta magáról, hogy igaz-e, nem tudom. Az e-maileket ettöl az ismeretlentöl »informátor 1944« név alatt kaptam. Ez az informátor annyit közölt még Csatáry Lászlóról, hogy ö volt a kassai gettónak a parancsnoka.

Ezt követően én kezdtem el vizsgálódni az iránt, hogy helytállóak-e az e-mailekben foglaltak. Ennek során azt állapítottam meg, hogy a második világháború alatt Kassán két gettó volt, és egy Csatáry László nevü személy volt annak a gettónak a parancsnoka, ahol azok a zsidók voltak bezárva, akik korábban valamilyen kitüntetésben vagy egyéb elismerésben részesültek a magyar államtól, illetve elsö világháborús veteránok voltak. Ebben a gettóban ezer zsidó volt. Az általuk összegyüjtött anyagokból az derül ki, hogy Csatáry László rendkivül kegyetlenül bánt azokkal a zsidókkal, akik oda abba a gettóba voltak zárva. A meglévö adatok szadistának titulálták. A feljelentésemhez csatolt mellékletböl számomra az derül ki, hogy a parancsnoksága alatt lévö embereket rendszeresen kínozta, és olyan feladatok elvégzésére kényszerítette, amelyen még az SS katonák is megbotránkoztak.

Kérdésre elmondom, az eddigi adatgyüjtésünk során nem merült fel még arra adat, hogy Csatáry László személyesen ölt volna meg egy vagy több embert. Tehát, ahogy említettem, az emailekben az ismeretlen arról is tájékoztatott bennünket, hogy ez a bizonyos Csatáry László itt, Budapesten a XII. kerület Györi u. 3. szám alatt lakik, és közölte azt is, hogy a GEG-784 frsz-ú Ford Scorpio típusú személygépkocsit használja. Az adatgyüjtésünk során megadott lakcím közelében valóban megtaláltuk parkolva a GEG-784 frsz-ú Ford Scorpio típusú személygépkocsit. Egyedüli problémám az, hogy személyesen nem láttuk, és nem is találkoztunk Csatáry Lászlóval.

Véleményem az, hogy az informátor által elmondottak kivétel nélkül igaznak bizonyultak, ezért nagy valószínüséggel az is helytálló, hogy arról a Csatáry Lászlóról van szó, aki ténylegesen a Kassán felállitott egyik gettó parancsnoka volt. Ezért kérem az ügyészséget, hogy állapitsák meg erröl a Csatáry Lászlóról van-e szó és amennyiben igen, úgy kérem hogy vele szemben háborús büntett elkövetése miatt járjanak el. Az informátor annyit közölt még, hogy rendkivül jó egészségi állapotban van, úgy néz ki mint egy hetven éves, de vigyázni kell vele, mert ha megneszeli, hogy ellene valamilyen eljárás folyik, akkor Angliában élö lányához vagy esetleg Portugáliába költözik. Azt is leírta, hogy a lánya rendkivül jó anyagi körülmények között él.

A meglévö adatok birtokában egyéb kutatásaink alapján találtunk egy olyan Csatáry Lászlót, aki 1915. március 3.-án született, és aki Kanadába ment a második világháború után. Tudomásom szerint Csatáry Lászlót 1948-ban itt, Magyarországon az általa elkövetettek miatt halálra itélték távollétében.

Csatáry László, - akit teljes nevén Csizsik-Csatary Lászlónak hívnak - 1949-ben érkezett Kanadába, ahol 1955-ben kapta meg az állampolgárságot. 1997-ben veszitette el kanadai állampolgárságát, mert a kanadai állam a múltban elkövetett háborús cselekményeinek elhall- 
gatása miatt megfosztotta ettöl. Az 1997-es kanadai döntés azt tartalmazza, hogy az állampolgárságtól való megfosztás alapját az képezte, hogy elhallgatta egyrészröl azt, hogy a Magyar Királyi Rendörségnek volt tagja, másrészről pedig azt, hogy közremüködött zsidók gettókba zárásába és koncentrációs táborokba való küldésében 1944-ben. A döntés ellen nem élt jogorvoslattal, és önként elhagyta Kanadát.

Kérdésre elmondom, amikor megkérdeztem az ismeretlen informátoromat, hogy az ö általa megjelölt Csatáry László mióta él Budapesten, akkor azt válaszolta nekem, hogy 1997. óta. Söt, még azt is megirta, hogy a XII. ker. Györi u. 3. szám alatt 2003. óta él. Az informátor közölte azt is, hogy a lakás tulajdonosa a lánya, akit Smithnek hívnak.

Kaptunk egy listát a Csehszlovákiai Zsidók Egyesületétöl azokról a túlélökröl, akik annak idején Kassán éltek, illetve a gettóba voltak zárva. Ezek mindegyike jelenleg Izraelben él és több mint valószinüleg kivétel nélkül beszélnek magyarul." 21

Efraim ZUROFF a 2012. VI. 5-ei keltezésű, Budapesti Nyomozó Ügyészségnek írt levele szerint dr. CSATÁRY László Lajosnak 1941 júliusában szerepe volt abban is, hogy háromszáz, magyar állampolgársággal nem rendelkező, Kassán élő zsidó származású személyt — férfiakat, nőket és gyerekeket - deportáltak Kamenyec-Podolszkíj-ba Ukrajnába, ahol őket megölték.

Az ausztráliai Sydney-ben élő WEINBERGER Marika állítása szerint, dr. CSATÁRY László Lajosnak a deportálásoknál kiemelkedő szerepe volt abban, hogy személyesen rendeltette vissza Kassára a munkaszolgálatból három nagybátyját, hogy őket is deportálni lehessen Ukrajnába, ahol mindhármukat megölték.

Efraim ZUROFF az ügyészégnek eljuttatott levelében leírtakat 2012. VII. 9-én Budapesten történt tanúkihallgatása során megerösítette.

„Annyit kívánok pontositani a feljelentésemen, hogy az általam megnevezni nem kívánt informátoromról akkor még nem tudtam, hogy férfi vagy nö, de most már tudom, hogy férfi, de nevét most sem tudom. Elmondani kivánom, hogy eredeti feljelentésemet az alábbiakkal kivánom kiegésziteni. Körülbelül egy hónappal ezelött kapcsolatba léptem egy Ausztráliában, Sidneyben élö hölggyel. Ö holokauszt túlélö, és a háború idején Kassán élt. Elsö beszélgetésünk során Csatáry László szerepéről beszélgettem vele, az 1944 tavaszán történt auschwitzi deportálások kapcsán. Ennek során egy nagyon érdekes gondolatot vetett fel.

Elmondása szerint Csatárynak szerepe volt abban is, hogy 1941. nyarán Kassáról magyar ál-lampolgársággal nem rendelkezö zsidókat deportáltak a jelenleg Ukrajnához tartozó Kamenetz-Podolskba. Magyarázatképpen el kivánom mondani, hogy saját ismereteim szerint körülbelül 18000 Magyarországon élö, de magyar állampolgársággal nem rendelkezö zsidót tartóztattak le 1941 nyarán Magyarország egész területén, és deportálták őket Kamenetz-Podolskba, ahol öket szinte kivétel nélkül meggyilkolták.

Visszatérve a hölgy által elmondottakra, állitása szerint családjának kilenc tagját deportálták igy, és őket mindannyiukat Kamenetz-Podolskban gyilkolták meg. Természetesen ezt ez a hölgy csak a háború után tudta meg. Ezt úgy pontositom, hogy a halálukat csak a háború után erösitették meg.

Ez a hölgy Csatáry szerepéröl elmondta, hogy négy nagybátyját korábban munkaszolgálatra vezényelték, de Csatáry kifejezetten személyesen eljárva visszahozatta öket Kassára, hogy a többi zsidóval együtt öket is deportálhatni lehessen. Szintén saját tudomásom, hogy mintegy 300 zsidót deportáltak igy csak Kassáról. [...]

Közölni kivánom Csatáry László általam ismert jelenlegi tartózkodási helyét. Tudomásom szerint ugyanis már nem a Györi utca 3. szám alatt lakik, hanem a Budapest XI. kerület Jagelló utca 4/A. szám alatt a földszint 2. lakásban.

Kérdésre elmondom, hogy nem vagyok benne teljesen biztos, hogy Csatáry László miért költözött el, de elképzelhetö, hogy ez visszavezethetö arra, hogy felkerült a Wiesenthal Központ által készitett és a tíz legkeresettebb háborús bünöst megnevezö listára. Az eredeti informátorom elöször azt mondta, hogy Csatáry László esetleg külföldre fog menekülni, de idöközben tudomására jutott az új lakcim. Magam nem vagyok teljes mértékben biztos, hogy Csatáry László külföldre menekülne, de ennek a lehetösége mindenesetre fennáll. Véleményem szerint ezt minden eszközzel meg kell akadályozni, hiszen ha elmenekül, sokkal nehezebb lesz öt eljárás alá vonni, illetve az ö ügyében igazságot szolgáltatni. Csak remélni tudom, hogy az Önök hatóságának meg lesz a menekülése megakadályozásához elégséges ereje és módja.",22

Efraim ZUROFF 2011. IX. 21-én tett feljelentéséhez két országban lefolytatott népbírósági eljárás anyagait vette alapul. 
Az egyik, a Magyarországon az 1945-1946-ban zajló 197/1946. számon a budapesti népbíróság által lefolytatott büntetőeljárás, amely dr. HORVÁTH György volt kassai rendőr-főkapitány helyettes ellen indult többek között az 1944-es kassai deportálások során elkövetett háborús büncselekmények miatt, és amely eljárás során dr. CSATÁRY László Lajos rendőrségi segédfogalmazó neve is felmerült.

A másik, Szlovákiában 1947-1948-ban a kassai népbíróság által dr. CSATÁRY László Lajos (Dr. Ladislav / Lászlo / CSATÁRY) volt magyar kassai rendőrkapitány ellen indult fasiszta megszállás és kollaboráció, benne az 1944-es kassai deportálások során elkövetett háborús büncselekmények miatt lefolytatott eljárás. ${ }^{23}$

Mind a magyarországi, mind a szlovákiai ügyekben jogerős bírói ítéletek születtek. A kihallgatott tanúk vallomásaikat eskü alatt tették meg.

Efraim ZUROFF a 2011 szeptemberében Budapesten tett feljelentését 2012 június elején kiegészítette azzal, hogy az Ausztráliában élő WEINBERGER Marika kilenc családtagjának 1941 augusztusában Kamenyec-Podolszkij-ba történt deportáltatása és haláluk, kifejezetten dr. CSATÁRY László Lajos közremüködésével történt. A feljelentésében leírtakat és az általa a későbbiek során beterjesztett újabb „bizonyítékokat” elégségesnek vélte annak bizonyítására, hogy dr. CSATÁRY László Lajos a 2011-ben hatályban lévő magyar Büntetőtörvénykönyv 165.§-a szerinti egyéb háborús büntettnek minősülö büncselekményeket elkövette.

2012 augusztusában a kassai ügyészséghez érkezett feljelentés szerint dr. CSATÁRY László Lajos „volt magyar kassai rendőrkapitány” felelőssége volt egy tizenhét éves kassai illetőségü fiú 1945. I. 10-én történő elfogása és deportálása. ${ }^{24} \mathrm{Ez}$ a feljelentés egy újabb háborús büncselekmény elkövetése miatti ügy Szlovákiában induló bírósági eljárás lehetőségét vetette fel. ${ }^{25}$

Efraim ZUROFF reményei szerint a 2011 szeptemberében tett feljelentése alapján indult büntetőeljárás olyan bírósági ítélettel zárulhat, amelyhez időközben egyesíthetik a 2012 őszén Kassán feljelentett újabb ügyet.

\section{A dr. CSATÁRY László Lajos személyének tulajdonított jogsértések}

2012 áprilisa és 2013 augusztusa között a médiában megjelenő magyar és külföldi sajtócikkek, videó riportok, túlélők, tanúk, szemtanúk visszaemlékezései, a különböző interjúk, tanulmányok médiában megtörténő publikálása és a Budapesti Nyomozó Ügyészség által nyilvánosságra hozott gyanúsítás alapján állt össze az a felsorolás, amely az 1941 júliusa és 1945 januárja közötti időszakban Kassán a dr. CSATÁRY László Lajosnak tulajdonított, vagy az ő vélt közremüködésével elkövetett jogsértéseket, eseményeket, eseteket foglalta össze.

Dr. CSATÁRY László Lajos Magyar Királyi Rendőrség segédfogalmazójának „,bünlajstroma”:

- 1941. július-augusztusban Kassán tevékenykedett, és befolyását latba vetve a munkaszolgálatból visszarendelt háromszáz zsidó személyt — többek között WEINBERGER Marika kilenc rokonát —, akiket deportált Ukrajnába Kamenyec-Podolszkij-ba, ahol őket szinte kivétel nélkül meggyilkolták. ${ }^{26}$

- 1944. április-május-június hónapokban a Kassán létrehozott téglagyári internálótábor elöljárójaként vagy többek szerint gettóparancsnokként puszta kézzel és kutyakorbáccsal rendszeresen, minden különösebb indok nélkül verte és bántalmazta az internáltakat nemre, korra és egészségi állapotra tekintet nélkül, így például KOVÁČ Emilt és feleségét, SCHWARTZ Žigmundot és GÁDOR Františeket.

- Kassai rendőrkapitányként dr. CSATÁRY László Lajos adta ki azt a parancsot, amely alapján a téglagyári internáló táborból szökést megkísérlökre felszólítás nélkül kell lőni.

- A téglagyári internáló táborban fogva tartott közel 12000 zsidó személyt 1944. május közepe és június eleje között, összesen négy-öt transzporttal, vasúti úton, tehervagonokba zsúfolva különbözö, a németek által megszállt területeken lévő koncentrációs táborokba deportáltatta, és tudomása volt arról is, hogy a deportálandók olyan körülmények közé kerülnek, ahol életük és testi épségük veszélybe kerül.

- A zsidóság előbb gettóba, majd a téglagyári internáló táborba szállításánál, később az elszállítandók kijelölésénél és a csendőrségnek átadásnál tevékenyen közremüködött, és az egyes transzportok elindításánál jelen volt.

- A negyedik transzport elindítását megelőzően, 1944. VI. 2-án a deportálandók közé tartozó BALKÁNYI Sándor arra vonatkozó kifejezett kérése ellenére megtiltotta, hogy a körülbelül 
nyolcvan fövel telezsúfolt, ablaktalan tehervagonokon az abban tartózkodók amúgy is embertelen körülményeinek megkönnyítése érdekében ablakokat vágjanak. ${ }^{27}$

- 1944 novemberében a Magyar Királyi Rendőrség kassai rendőrkapitánysága politikai rendőrségi részlegének elöljárójaként — a szlovákiai népbírósági eljárásban, mint volt magyar kassai rendörkapitány -, több száz demokratikus gondolkodású, illetve általa kommunistának bélyegzett személyt vetetett őrizetbe, akiket később a német, illetve magyar hatóságok által foganatosított formális — a bántalmazásokat, illetve a kényszervallatást sem nélkülözö — kihallgatásokat követően vagy több esetben kihallgatás nélkül előbb Komáromba, majd különböző koncentrációs táborokba deportáltatott. Egyes ilyen módon örizetbe vett személyek, mint például SCHMUTZER József bántalmazásában személyesen is részt vett, míg más személyek nevezetesen SEMETKAY Mikuláš bántalmazásánál csak jelen volt, de azt semmilyen módon nem akadályozta meg, és erre kísérletet sem tett.

- 1944. XI. 7-én letartóztattatta ZSUROVSZKY Zoltán kassai lakost, aki ellene 1944. XI. 4-én fegyveres merényletet kísérelt meg, és a letartóztatott személy bántalmazásánál jelen volt.

- 1944 novemberében - mint a Nyilaskeresztes Párt DARABOS László által vezetett kassai szervezetének a tagja — részese volt mintegy kétszáz fö tehervagonokban deportált zsidó személy gázzal történt kivégzésének. ${ }^{28}$

- 1944 novembere és 1945 januárja között Kassán több mint ötszáz embert gyilkoltak meg a nyilas hatalom képviselői, amely tettekért dr. CSATÁRY László Lajos is felelős.

- 1945. I. 5-én Kassa Fő utcáján tizenkét katonaszökevényt és partizángyanús személyt akasztatott fel.

- 1945. I. 10-én dr. CSATÁRY László Lajos és társai ok nélkül letartóztattak, majd a kassai rendőrkapitányság Moyzes utcai épületében fogva tartottak egy tizenhét éves kassai férfit. Az érintettet később kényszermunkára egy pontosabban nem meghatározott németországi helyszínre deportálták, ahonnan csak 1945. VIII. 14-én tért vissza Kassára. A büncselekményt az elkövetők az államhatalom képviselöiként követték el.

- Kassa felszabadulása előtt két nappal, 1945. I. 17-én, a Ťahanovsky-alagút mellett tizenhét embert lőttek agyon bestiális módon. A tettekért dr. CSATÁRY László Lajosnak is viselni kell a felelősséget, aki abban az időben magas rangú rendőri tisztviselőként a transzportok megbízott szervezője és a Nyilaskeresztes Párt rendkívül aktív tagja volt.

\section{A dr. CSATÁRY László LAJOS ügy feltárása, a bizonyítékok és tények felkutatása}

Dr. CSATÁRY László Lajos büntetőeljárás alá vonását követő időszakban a mindennapos beszélgetések alkalmával sorra elevenedtek fel olyan események, időpontok, történések emlékei, amelyeket józan ésszel végiggondolva a felrótt büncselekmények fizikai megvalósulásának lehetetlenségét vetették fel. Dr. CSATÁRY László Lajos visszaemlékezései mind helyszínekre, mind időpontokra, mind történésekre vonatkozóan olyan részletesek és pontosak voltak, melyet csak olyan valaki tud többször is ugyanúgy felidézni és azokra később visszatér-ve részleteiben is tovább pontosítani, aki azokat át- és megélte. Dr. CSATÁRY László Lajos a Budapesti Nyomozó Ügyészségen gyanúsítottként történő kihallgatásai során és beadott indítványaiban tételesen és összefüggéseiben is cáfolta mind az Efraim ZUROFF feljelentésben, mind a médiában megjelenő terhére rótt cselekményeket.

Dr. CSATÁRY László Lajos védelmét kirendelt védő látta el, mert megbízásos alapon erre egyetlen ügyvéd sem vállalkozott köszönhetően annak a közhangulat alapján kialakult véleménynek, amely szerint „hogyan lehet egy ilyen embert védeni?!” Ez, valamint az a körülmény, hogy házi őrizete során mindössze napi két óra idötartamban hagyhatta el lakását, az érdemi és cáfoló bizonyítékok felkutatásán alapuló védekezésének lehetőségét eleve kizárta.

Dr. CSATÁRY László Lajos 2012. VII. 18-án történő házi őrizetbe helyezését követő hónapok során többször felmerült annak gondolata, hogy a kihallgatásokon az általa elmondottakat alátámaszthatják olyan levéltári dokumentumok, amelyek bizonyítékul szolgálhatnak a minduntalan felmerülő vétlenségére vonatkozóan.

2012 őszén kezdődött meg a munka, amely a számításba vehető levéltárak és közkönyvtárak archívumaiban lévő több ezer oldalnyi dokumentum elolvasása és tanulmányozása során tárta fel azokat a bizonyítékokat, amelyek a dr. CSATÁRY László Lajos ügyben végül a valóságot hozták felszínre.

A nyomozó-kutató munkával kapcsolatban sok esetben elhangzik a meggyőződés szó és az, hogy hinni kell az ügyben. Ez így nem teljesen valós, mert a nyomozás sikere nem hit, illetve 
meggyőződés kérdése. A nyomozás eredményessége az ügy alapos megismerésén, megtanulásán, a cáfolhatatlan bizonyítékok felkutatásán, azok helyes értékelésén, elemzésén és megfelelő logikai sorrendbe történő illesztésén múlik.

Az előkészítés során kutatási terv készült, amely meghatározta az elvégzendő feladatokat, a kutatásra kerülő időszakot, a kutatás módját, irányát és azok helyszíneit, de egyben lehetőséget hagyva az esetleges újabb felmerülö események, momentumok megismerésének.

A kutatómunka a magyar és külföldi levéltárakban, közkönyvtárakban fellelt több ezer oldalt kitevő archivált irat, könyv, több száz méter mikrofilm elolvasása, tanulmányozása, az ügyhöz kapcsolódó bizonyítékok, iratok dokumentálása, valamint a dr. CSATÁRY László Lajos birtokában lévő dokumentumok, okmányok megismerése, tanulmányozása során és alapján zajlott.

A kutatás során a következő anyagokat vizsgáltam:

- A budapesti népbíróság eljárásának Budapest Főváros Levéltárában archivált peranyaga, amely dr. HORVÁTH György volt kassai rendőr-fökapitány helyettes, háborús föbünös ellen folyt, és amelynek tanúvallomásaiban több alkalommal felmerült dr. CSATÁRY László Lajos rendőrségi segédfogalmazó neve. ${ }^{29}$

- A kassai népbíróság dr. CSATÁRY László Lajos volt magyar kassai rendôrkapitány ellen lefolytatott eljárása Kassai Állami Levéltárban kutatható peranyaga. ${ }^{30}$

- Azok a dokumentumok, amelyek 1993 és 1997 között a Kanadai Szövetségi Bíróság által kezdeményezett és a Kanadai Királyi Szövetségi Rendőrség által Szlovákiára, Szlovéniára, Magyarországra, Izraelre, Kanadára és az Egyesült Államokra is kiterjesztett, „Ladislaus CSIZSIKCSATARY” 1944-es kassai tevékenységének nemzetközi nyomozása során keletkeztek. ${ }^{31}$

- Dr. CSATÁRY László Lajos magándokumentumai.

\section{A dr. CsatáRY László Lajosnak felrótt cselekmények, események és azok dokumen- tumokkal bizonyított cáfolatai}

\section{A Kassáról Kamenyec-Podolszkij-ba történő deportálások}

Efraim ZUROFF feljelentése az Ausztráliában élö WEINBERGER Marika elmondásán alapul, amely szerint rokonainak deportálására 1941 nyarán került sor, és amely esemény végrehajtójának neve dr. CSATÁRY László Lajos rendőrségi segédfogalmazó volt, akinek nevéről az adatokat szolgáltató személynek az édesapja elmondásából volt tudomása.

Ehhez Efraim ZUROFF a 2012. VII. 9-én tett tanúvallomásában a továbbiakat teszi hozzá: „Szintén saját tudomásom, hogy mintegy 300 zsidót deportáltak igy csak Kassáról.” A tények és bizonyítékok azonban cáfolják mind a feljelentő, mind az információt adó személy állításait.

A Budapesti Nyomozó Ügyészség által kirendelt történész-szaktanácsadó a Magyarország Tiszti Név-és Címtár és a Rendörségi zsebkönyv 1941. évre vonatkozó adatai alapján megállapította, hogy dr. CSATÁRY László Lajos 1941-ben fogalmazó gyakornokként Kecskeméten, majd 1942-ben Kecskeméten és Zomboron segédfogalmazóként teljesített szolgálatot, és csak 1943-tól szolgált a kassai rendőrkapitányságon.

A kutatások során dr. CSATÁRY László Lajos magándokumentumaiból és a Magyar Nemzeti Levéltárból erre az időszakra vonatkozóan további bizonyítékok kerültek elő.

A kinevezési okmány ${ }^{32}$ (II.sz. melléklet) tanúsága szerint a belügyminiszter dr. CSATÁRY László Lajost 1940 januárjában a Magyar Királyi Rendőrséghez fogalmazó-gyakornoknak nevezte ki Kecskemétre. Közel két év után 1941 decemberében Kecskeméten minősítették át segédfogalmazóvá ${ }^{33}$ (III.sz. melléklet), majd 1942 márciusában Kecskemétről Zomborba helyezték át. ${ }^{34}$ (IV.sz. melléklet)

A Kassáról Kamenyec-Podolszkij-ba történő deportálásokkal és gyilkosságokkal kapcsolatos feljelentés ügyében kirendelt történész-szaktanácsadó megállapításait tehát alaposan megtámogatják azok az előkerült magán- és levéltári dokumentumok, amelyek azt bizonyítják, hogy dr. CSATÁRY László Lajos fogalmazógyakornok 1941. július-augusztusban nem tartózkodott Kassán.

Nem életszerủ az sem, hogy dr. CSATÁRY László Lajos rendőr fogalmazógyakornok Magyarország hadba lépésének idején a Kecskeméttől mintegy 350 km-re lévő Kassa városába pár hétre csak úgy átugrott volna néhány száz személyt deportálni.

\section{Dr. CSATÁRY László Lajos, mint gettóparancsnok?}


Dr. CSATÁRY László Lajost a feljelenő és néhány, az ügyben megszólaló történész-jogász és újságíró a „sajátos" módon végzett kutatásaik alapján tett megnyilatkozásaik, valamint a népbírósági eljárásokban a túlélő tanúk vallomásaikban gettóparancsnokként említették.

A gettóparancsnoki pozíció betöltés vádjának szolgál alapjául egy 1944. V. 1-én kiadásra került, és az Országos Széchényi Könyvtárban fellelhető „HIRDETMÉNY” (V.sz. melléklet) illetve annak lábrészében olvasható felsorolás szövege: „, $F$. k.: Dr. Csatáry László rendőr fogalmazó, Gettó-parancsnok.", valamint a HIRDETMÉNY alsó részének jobb oldalán kissé feljebb a kiadás dátumával egyvonalban olvasható „Gettó-parancsnok” szöveg.

Dr. CSATÁRY László Lajos nem rendelkezett intézkedési, vagy kiadmányozási joggal, továbbá önmagát sem léptethette volna elő rendőrségi segédfogalmazóból rendőr fogalmazóvá, nem beszélve a gettóparancsnoki kinevezésról.

Az intézkedési, vagy kiadmányozási jogokról a belügyminiszter rendeletet bocsátott ki, ${ }^{35}$ továbbá a Magyar Királyi Rendőrség Szervezeti és Ügyviteli Szabályzata ${ }^{36}$ benne a vidéki rendör-fökapitány helyettes ügykörére vonatkozó szabályozás rendelkezett. ${ }^{37}$

A hatóságok kiadmányainak tartalmáért a kiadó hatósági személy felelt. A felhívásnak alaki tekintetben meg kellett egyeznie a hatósági kiadványok követelményeivel. A kiadmányozással kapcsolatban lényeges volt még hogy: intézkedési, vagy kiadmányozási jogukat a hatósági személyek az ilyen joggal fel nem ruházott más személyekre nem ruházhatták át, valamint csak olyan tisztviselö írhatta alá a kiadmányt, aki erre egyénileg jogosult volt.

Dr. CSATÁRY László Lajos rendőr segédfogalmazói beosztásánál fogva sem önálló kiadmányozásra, sem önálló intézkedésre nem volt jogosult. Kassán erre és az ehhez hasonló intézkedésre kizárólag csak egy személynek dr. HORVÁTH György Kassa város vidéki rendőrfö-kapitány helyettesének volt jogosultsága.

A HIRDETMÉNY lábrészének szövege alapján dr. CSATÁRY László Lajos gettóparancsnokként való értelmezése arra utal, hogy az erre hivatkozó nem ismeri a felelős kiadó hatáskörére, illetékességére vonatkozó meghatározást, és nincs tisztában a magyar nyelv helyesírási, valamint a tulajdonnevekre és névmásokra vonatkozó szabályaival sem.

Ezért fordulhat elö, hogy a HIRDETMÉNY-re vonatkozó cikkekben, írásokban, valamint holokauszt témájú $\mathrm{PhD}$ disszertációban is hivatkoznak „Csatáry László rendőr fogalmazó parancsára". ${ }^{38}$

A gettóparancsnok az akkori kassai vidéki rendőr-főkapitány helyettes, dr. HORVÁTH György személyét takarta, mint ahogy például a kormányzó vitéz nagybányai HORTHY Miklóst, vagy a nemzetvezető SZÁLASI Ferencet.

Ha a beosztás viselőjének személye időközben változik is, emiatt nem kell újból a hirdetményt, vagy utasítást kiadni.

Dr. CSATÁRY László Lajos beosztásainak több helyen is tévesen történő meghatározása kérdésében egyértelmü és pontos választ ad a Magyar Nemzeti Levéltárban kutatható Magyarország tiszti cím- és névtára 1944 júliusában kiadott pótfüzete, amely a „,nagymérvű változások” miatt csak ekkor jelenhetett meg. ${ }^{39}$

A pótfüzet előszavában a szerzők azt is megindokolták, hogy mi volt az oka az 1944 júliusában történő kiadásnak. A kötet kiadása időpontjában Magyarország már 1944. III. 19. óta német megszállás alatt állt, ezért az erre való utalással — „ . . . a szerkesztés alatt beállott és a szerkesztöség tudomására jutott nagymérvü változások figyelembevétele, a nyomdai munkák elörehaladott volta mellett csak a megjelenés idöpontjának lényeges kitolásával lett volna lehetséges." 40 — erősen árnyalt megfogalmazásban került nyomdába.

1944. június első napjaiban befejeződtek a Kassa és környéke zsidóságát érintő tömeges deportálások, azonban dr. CSATÁRY László Lajos beosztása ezt követően sem változott, továbbra is a kassai rendőrkapitányság segédfogalmazójaként teljesített szolgálatot.

Dr. CSATÁRY László Lajos gettóparancsnoki kinevezésére, megbízására vonatkozóan a levéltárakban nem lelhető fel semmilyen irat, dokumentum, adat, feljegyzés, vagy bármilyen más erre utaló bizonyíték. Gettóparancsnoki mivoltával és tevékenységével a sajtóban és a személyével 2012 nyarán a Budapesti Holokauszt Emlékközpontban a dr. CSATÁRY László Lajossal kapcsolatban megrendezett „konferencián” bemutatásra kerültek olyan feljegyzések, jelentések, amelyeken az aláírások mindegyikét dr. CSATÁRY László Lajosnak tulajdonították. A dokumentumokra az Állambiztonsági Szolgálatok Történeti Levéltára világhálós folyóiratában is történt hivatkozás. ${ }^{41}$ A korabeli és mindössze négy nap eltéréssel keletkezett jelentéseken látható aláírások között, azonban a laikus számára is jól érzékelhető a nagymértékü különbözőség. 
Mindezek alapján felmerül a gyanú, hogy mind az 1944. V. 1-én kiadott HIRDETMÉNYen, mind a felkutatott és publikussá tett jelentéseken, feljegyzéseken dr. CSATÁRY László Lajos rendőr segédfogalmazó nevével és aláírásával valaki, vagy valakik gátlástalan módon visszaéltek.

Történelmi tények, bírósági ítéletek ${ }^{42}$ és történész-kutatók müvei, többek között a sokak által hivatkozott Randolph L. BRAHAM „A népirtás politikája”43 címü könyve bizonyítják, hogy a kassai gettó létrehozásának egyik felelőse dr. HORVÁTH György vidéki rendőr-fökapitány helyettes volt. Randolph L. BRAHAM maga is bizonytalan a téglagyári gettóparancsnok valós személyének kérdésében, mert hol dr. CSATÁRY László Lajost, hol SzOÓ Tibor felügyelö-gyakornokot nevezi meg.

Randolph L. BRAHAM dr. CSATÁRY László Lajos „,bünös tevékenységének”44 és gettóparancsnoki voltának kritika nélkül elfogadott hiteles bizonyítékaként az Észak-Amerikában élő zsidóság MENORA-EGYENLÖSÉG címü újságjának 1984. VI. 1-ei számában „HALÁLVONATOK" címmel ${ }^{45}$ közzé tett dr. GASKÓ Miklós kassai ügyvéd írását jelöli meg, amely cikk már az elején közli, hogy az abban leírtak másoktól kapott információkon, elmondásokon, hallomásokon alapulnak. Dr. GASKÓ Miklós a cikket a dr. CSATÁRY László Lajos ellen lefolytatott nyilvános kassai népbírósági eljárást követően harmincöt évvel később írta meg.

Jogosan merül fel a kérdés, hogy miképpen lehet történelmi forrásalapként kezelni egy mások visszaemlékezésein és hallomásokon alapuló újságcikket.

Randolph L. BRAHAM „A népirtás politikája” címü könyvében jelzi ugyan, hogy tulajdonában van a dr. HORVÁTH György elleni eljárás tárgyalási anyaga, azonban elemző értékelésének és a dr. CSATÁRY László Lajos elleni kassai népbírósági anyaggal történő összevetésének hiányában a dr. CSATÁRY László Lajosra vonatkozó kutatási eredmény objektivitása, valóság tartalma teljes mértékben megkérdöjeleződik. ${ }^{46}$

A 2003-ban Jeruzsálemben a Jad Vasem intézet adta ki „A szlovákiai zsidó közösségek enciklopédiája”-ját, amely a világhálóra is felkerült. A kiadvány „Kassa” címü fejezete foglalkozik a Kassa és környéke zsidóságának deportálásával. ${ }^{47} \mathrm{~A}$ publikáció is azt bizonyítja, hogy a kassai téglagyári gyüjtőtábor elöljárója nem dr. CSATÁRY László Lajos, hanem SzOÓ Tibor rendőrfelügyelö gyakornok volt. SzoÓ Tibor téglagyári gettóparancsnok voltát mind a budapesti, mind a kassai népbírósági eljárásokban több tanúvallomás erősítette meg.

Az említett enciklopédiát Efraim ZUROFF is csatolta a dr. CSATÁRY László Lajos ellen tett feljelentéséhez, benne a téglagyári gyüjtőtábor vezetőjére Szoó Tiborra vonatkozó utalással.

\section{A Magyarországon és Szlovákiában lefolytatott korabeli népbírósági eljárások során rög- zített vallomásokban és vallomások között felmerülő ellentmondások}

KoVÁČ Emil és felesége megkínzására, verésére, majd szökési kísérletük során történt lelövésükre vonatkozó vádak ellentmondásai

Dr. JÓNAP Sámuel KOVÁČ Emil és feleségére vonatkozó vallomásának részlete az 1948-ban dr. CSATÁRY László Lajos ellen lefolytatott kassai népbírósági eljárás tárgyalási jegyzőkönyvének magyar nyelvü fordításából: „Személyesen láttam a vádlottat, amint verte Kováč Emilt és feleségét." ${ }^{48}$ KovÁČ Emil és felesége megveréséröl mindössze ez a tíz szóból álló mondat hangzott el. A tárgyalási jegyzőkönyv nem tartalmaz kérdést a bíró részéről arra vonatkozóan, hogy a tanú honnan látta, hol, mely helyszínen, hogyan történt, milyen eszközzel, puszta kézzel, mikor, melyik napszakban, voltak-e ott mások is, hangzott-e el valamilyen kínzással összefüggésbe hozható kijelentés. A vallomás értéke ennél fogva gyenge, tényhiányos és bizonytalan.

Dr. JÓNAP Sámuel tanúvallomásának folytatásában a következőkről beszél: ,, A vádlott kiadta a parancsot az öröknek, hogy abban az esetben, ha valaki szökést kísérel meg, azt helyszini vizsgálat nélkül a helyszínen azonnal löjék le. Így történt, hogy Kováč Emil felesége, ö maga a gyermekük és még egy nö a szökés közben elfogásra kerültek, és ugyan felszólitásra megálltak, az elöbbi parancs alapján a tett helyszinén azonnal lelötték öket." 49

Dr. SzÁSZ Elemér tanúkihallgatásán a budapesti népbírósági eljárás során a Politikai Rendészeti Osztályon ugyanerről az eseményről azt vallotta, hogy: „Egy este Dr. Horváth fökapitány-helyettes a jelenlétemben és fülem hallatára a következö utasitást adta ki:

Az örszemeket figyelmeztetni, hogy mindenkire, aki a keritéshez közeledik, még ha azt nem is lépi át, azonnal rá kell löni. Ennek az utasitásnak következményeképpen éjjel is lövöldözést 
lehetett hallani, és másnap reggelre a táborban három halott volt, egy férfi és két nö, akiknek ne-vét nem tudom. Az egyik nöi halott egy kassai orvostanhallgató nö volt, akik a keritéshez közel mentek, és ezért a csendörlegénység lelötte öket." ${ }^{50}$

Dr. HORVÁTH György erről az esetről tett vallomása: „, A deportálások, május 15-én kezdődtek, $s$ én ez alkalommal nem adtam ki rendelkezést szigorúbb örzésre. Volt olyan rendelkezés, hogy aki szökik, azt agyon kell löni, de ez a parancs úgy lett tovább adva, hogy ne löjenek, mert úgyis kettös kordon örizte a tábort. Nem történt egyetlen fegyverhasználat sem, kivéve, amikor egy szadista csendör kb. 3-4 embert agyonlött. Én az ügyet kivizsgáltam, mikor azt jelentették nekem, hogy a már elfogott szökevényeket egy csendör a rendörök mellett önkényesen agyonlötte. A rendörség nem parancsolt a csendörségnek. "51

A dr. HORVÁTH György kassai rendőr-fökapitány helyettes, a kerítés megközelítése esetére kiadott fegyverhasználatra vonatkozó parancsát több tanúvallomás erősíti meg, többek között özv. FöLDES Jenőné vallomása: „,Amikor köztudomású volt a deportálás, de nem tudtuk hová, és ennek következtében a tábor lakói szökni próbáltak. Erre Horváth kiadta az utasitást az örségnek, hogy aki szökni próbál, és ha a keritéshez közeledik, azonnal le kell löni. Ilyen lövések több alkalommal is elöfordultak. ",52

Dr. JÓNAP Sámuel a kassai népbírósági eljárás során tett tanúvallomásában lévő jelentős ellentmondás, hogy a fegyverhasználatra vonatkozó parancsot nem dr. CSATÁRY László Lajos rendőr segédfogalmazó, „kassai rendőrkapitány” adta ki, hanem dr. HoRVÁTH György Kassa vidéki rendőr-főkapitány helyettese. Dr. JÓNAP Sámuel tanúvallomásának megalapozatlan voltát bizonyítja dr. HORVÁTH György vallomása, aki a gyanúsítotti kihallgatásán készült jegyzökönyvben kijelentette: „A táborban egy ilyen fegyverhasználatról tudok, azt is a csendörök követték el, és erröl jegyzökönyv is fel lett véve, ez az eset a tábor területén kívül történt. "53

Dr. JÓNAP Sámuel dr. SzÁsz Elemérrel ellentétben nem adott tényszerủ felvilágosítást arról, hogy a parancsot mikor, hol, milyen körülmények között, milyen esetre vonatkozóan kellett végrehajtani, és arra sem, hogy azt milyen egység (rendőrök, csendőrök) és a tábor területén, vagy azon kívül hol hajtotta végre. Tanúvallomását cáfolja az a több hiteles dokumentummal bizonyított tény, hogy a tábor külső fegyveres örzését a csendőrök végezték.

Dr. SzÁsz Elemér e vonatkozásban autentikus személy, mivel a kassai téglagyári gyüjtőtábor belső zsidó őrségének volt parancsnoka 1944. IV. 16-tól 1944. VI. 2-ig, az utolsó transzport elindításának napjáig. ${ }^{54}$ Történelmi tények és dokumentumok bizonyítják, hogy az utolsó transzport 1944. VI. 2-án indult Kassáról, amikor egyúttal a téglagyári gyüjtőtábort is felszámolták.

\section{SCHWARTZ Žigmund és dr. GADOR František megverése, bántalmazása}

A két személlyel kapcsolatos eseményt, ŠTRAKOVÁ Terézia Glücksmannová (GLÜCKSMANN Teréz) vallomását az 1948-as kassai népbírósági eljárás során a készült rendőrségi jegyzőkönyvben így rögzítették: „Elmesélek egy konkrét esetet: Körülbelül négy nappal azután, hogy a gyüjtötáborba kerültem, a délutáni órákban a tábor udvarán Csatáry ok nélkül elkezdte kínozni az én néhai nagybátyámat, Ing. Schvartz Žigmundot és a néhai Dr. Gádor Františeket; embertelenül kinozta öket korbáccsal, pofozta öket, és végül elövette és rájuk fogta pisztolyát, és azt ismételgette fenyegetözve, hogy lelövi öket." 55

A vallomás egy rokon elmondásán, elmesélésén alapul, aki hozzátartozóként elfogultnak mondható. A verés nem egyenlő a kínzással. Ha jogsértés valósult meg, az legfeljebb hivatali hatalommal való visszaélés, vagy bántalmazás hivatalos eljárásban lehetne.

ŠTRAKOVÁ Terézia tanúkihallgatási jegyzőkönyvének részlete: „,1947. november 29. napján a Slovan Kávézóban találkoztam egy hölggyel, akinek a nevére már nem emlékszem, ö mesélte nekem, hogy látta, amikor Csatáry a téglagyári táborban lelött egy lányt. "56 Vallomásának valóságtartalmát a fentieken túl erősen megkérdőjelezi, hogy más tanúk: dr. SZÁsz Elemér, dr. JÓNAP Sámuel és dr. HORVÁTH György egészen másképpen vallottak ŠTRAKOVÁ Terézia e tárgyban tett tanúvallomásával szemben, amelyre a kassai népbíróság a dr. CSATÁRY László Lajossal szemben hozott halálos itélet indokolásában is kitért.

Dr. PERÉNY Štefan a kassai népbírósági eljárás során eskü alatt tett tanúvallomásának részlete: ,Fenntartom az 1.17. szám alatt tett vallomásomat, és kiegészitem azzal, hogy csak Dr. Šimayová szájából hallottam, hogy nála volt elszállásolva egy SS kapitány, a vádlott és egy csendör örnagy, és egyszer ez az örnagy elmondta, hogy egy SS kapitány zsidóbarát a vádlotthoz képest. ",57 Vajon mi szükség lehetett ŠIMAYOVÁ-nál történő elszállásolására, ha dr. CSATÁRY 
László Lajosnak Kassán az Erdő utca 16. szám alatt volt az állandó lakása? Ez a vallomás is nyomós érv volt a szlovák népbírósági ítélet indokolásában, de egyúttal felveti azt a lényeges kérdést, hogy a kihallgatott tanúk tulajdonképpen kire vonatkozóan tették terhelö vallomásaikat?

\section{A vagonablakok kivágásának megtiltásán alapuló háborús büncselekmény vádja}

A háborús büncselekmény vádjának meghatározó pontja volt BALKÁNYI Sándor a Magyar Államrendőrség Budapesti Főkapitánysága Politikai Rendészeti Osztályán jegyzőkönyvezett tanúvallomása, amely szerint dr. CSATÁRY László Lajos 1944. VI. 2-án az utolsó, azaz a negyedik transzport indulásakor megtiltotta a vagonokon történő szellőzést biztosító ablakok kivágását. BALKÁNYI Sándor tanúvallomása: „,Amikor a bevagonírozások megkezdődtek, 4. transzporttal történt, ezt onnan tudom, hogy én és a családom a 4. transzporttal kerültem bevagonírozva. [...] Én személyesen odamentem Dr. Csatáryhoz, és kértem, hogy miután ezek külföldi vagonok, és nincsenek ablakkal ellátva, így kértem öt arra, engedje meg azok megnyitását. Ezt ő azzal utasitotta el, hogy amennyiben ezt mégis megtesszük, rögtönitélö biróság elé állit, állami vagyon rongálása címén. "58 BALKÁNYI Sándor a budapesti népbírósági eljárás tárgyalásán tett tanúvallomásában ez már így hangzott: ,, Ablakokat is kezdtünk vágni a kocsikon, de Csatáry megakadályozta. ${ }^{, 59}$ BALKÁNYI Sándor a budapesti népbírósági eljárás során az e tárgyban korábban a Politikai Rendészeti Osztályon tett vallomásának a népbírósági tárgyaláson önmaga mondott ellent, amellyel a korábbi vallomásait meg is cáfolja: „Balkányi Sándor tanú: Nekem is volt kivételezettségem Mihalovicstól, és mégis az elsö transzporttal vittek el. ",60

Az első transzport indítására 1944. V. 15-én került sor. BALKÁNYI Sándor tehát 1944. VI. 2-án nem lehetett résztvevője a negyedik transzport indulásának. Ha BALKÁNYI Sándor nem volt jelen, akkor mire alapozta vallomását?

Dr. JÓNAP Sámuel a kassai rendőrségen 1947-ben felvett tanúkihallgatási jegyzőkönyvben a negyedik, azaz az utolsó transzport indulásának körülményeiről így vallott: „A negyedik transzportnál, amely Košicéböl körülbelül 1944. június 2-án indult, 6 vagont jelöltek ki részünkre, ahol 300 súlyosan beteg és idős embert kellett elhelyeznünk, és a felsöbb magyar parancsnoktól engedélyünk volt a vagonokban jobb körülmények közt elhelyezni öket, priccseket beállítani. "61 Dr. JÓNAP Sámuel az 1944. VI. 2-ai utolsó, a negyedik transzport zsidó orvosaként a vagonablakok kivágásával kapcsolatos eseményről nem tett említést.

BALKÁNYI Sándor e háborús büncselekmény elkövetésére vonatkozó tanúvallomása tehát hamis és dr. CSATÁRY László Lajos által el nem követett, illetve egy megnemtörtént esemény elmondásán alapul.

\section{Konferencia dr. CSATÁRY László Lajosról a budapesti Holokauszt Emlékközpontban}

Dr. GELLÉRT Ádám nemzetközi jogász, történész 2012. VII. 25-én a budapesti Holokauszt Emlékközpontban dr. CSATÁRY László Lajossal kapcsolatos kutatásairól megtartott konferencia prezentációjában $^{62}$ többek között megemlítette WEISZER Rózsi budapesti Politikai Rendészeti Osztályon tett tanúvallomását: „A gettó területén a legnagyobb szigorúság és tettleges bántalmazások voltak. Ezeket a tettleges bántalmazásokat korbáccsal a tábor parancsnoka végezte, ennek a tábornak dr. Csatáry László $r$. s. fogalmazó volt. A táborparancsnok elrendelte a gettó területén különbözö munkálatok elvégzését szerszám nélkül, például földásás, amit a kezünkkel kellett elvégezni, téglahordás stb. A gettó területén nem hallgattak meg senkit, és ha valakinek panasza volt, akkor a zsidótanácshoz kellett fordulni, és ez a tanács közvetített a hármas bizottság tagjaival. Amikor Csatáry a gettó területén megjelent, pánikszerüen menekültek elöle, és az egész gettó lakósai elött köztudomású volt annak szadista természete" ${ }^{63}$ Dr. GELLÉRT Ádám WEISZER Rózsi vallomásának többi részletét azonban már nem tette közzé, amelyeket ugyanabban a Politikai Rendészeti Osztály jegyzőkönyvben rögzítettek: „Én a gettóba 1944. április 29-én kerültem, és onnant elkerültem, még mielött a deportálások megkezdödtek volna. "64 Vallomása második része: „Velem az történt 1944. június 15., hogy én beteg lettem, és már nem tartózkodtam a gettóban, és az utcán elfogtak a rendörök és bevittek a rendörség épületébe. "65 Majd néhány sorral lejjebb: „Megjegyezni kivánom, hogy engemet teljesen egyedül de-portáltak annak idején a kassai $r$. kapitányságról. "66 WEISZER Rózsi a budapesti népbírósági tárgyaláson 1946. III. 30-án már így tett vallomást dr. CSATÁRY László Lajosról: „, Úgy hallot- 
tam a többiektöl, hogy Csatáry az emberekkel szerszám nélkül végeztetett földmunkát. . . . Hallomásból tudom azt is, hogy Csatáry, akit csak talált, vert, úgyhogy menekültek elöle. ",67

WEISZER Rózsi dr. CSATÁRY László Lajossal soha nem találkozott, azonban ennek ellenére mégis pontosan határozta meg rendőr segédfogalmazói titulusát, valamint azt, hogy a tábor területén milyen események történtek, és hogy dr. CSATÁRY László Lajosnak milyen szerepe volt a kegyetlenkedésekben. Meghatározta továbbá, hogy a deportálásokkor hatvan-nyolcvan személyt zsúfoltak a vagonokba, akik között öreg, csecsemö, beteg, elmebajos stb. személyek voltak, és azt, hogy Kassáról 11000 személyt deportáltak. WEISZER Rózsi kimaradt a téglagyárban elhelyezett személyek teljes deportálásából. Tanúvallomása hamis, és teljes egészében a másoktól hallottakon alapul.

\section{Egy új túlélő szemtanú a dr. CSATÁRY László Lajos ügyben}

Sem az 1945-1946-os budapesti, sem az 1947-1948-as kassai népbírósági eljárás során nem került sor SALAMON Edit kihallgatására, aki BALASSA Zoltán kassai helytörténész , Csatáry László - egy köszivü kassai rendörtiszt” címü írásában a „Felvidék.ma” nevü világhálós újságban jelent meg, mint a téglagyári deportálások egyik túlélő szemtanúja. ${ }^{68}$

A Budapesten zajló dr. CSATÁRY László Lajos ügyben tanúként történő kihallgatására a 2012-ben megjelent cikket követően közel háromnegyed évvel később, 2013. II. 12-én a Kassai Rendőrkapitányságon került sor.

Részletek SALAMON Edit 2013. II. 12-én készült tanúkihallgatási jegyzőkönyve magyar nyelvű fordításából: „, [...]Nyomozó kérdése: Ki volt a gettó vagy a téglagyári gyüjtőtábor parancsnoka? Válasz: Nem emlékszem, de ez fölött az ember fölött még mint föparancsnok ott volt a Csatáry. Nyomozó kérdése: Honnan lehetett tudni, hogy ki a parancsnok? Válasz: Nem tudom. Nyomozó kérdése: Követtek el Ön ellen, vagy az Ön rokonai ellen, vagy az Ön ismerösei ellen bármilyen atrocitásokat a városi gettóban, illetve a téglagyári gyüjtőtáborban? Válasz: Nem, nem követtek. Nyomozó kérdése: Személyesen ismerte dr. Csatáry László Lajost? Válasz: Nem ismertem, csak távolról láttam öt. Nyomozó kérdése: Hányszor találkozott vele? Válasz: Soha nem találkoztunk, mint ahogy azt már mondtam, távolról láttam öt. Nyomozó kérdése: Tud róla részletes személyleírást adni? Volt neki valamilyen jellemzöje, szokásai, vagy szava? Válasz: Mint ahogy már mondtam, csak távolról láttam öt. Emlékszem, hogy magas volt, jóképü, kemény szivvel. Pontosabb leirást nem tudok adni róla. Nyomozó kérdése: Milyen öltözéket, milyen egyenruhát viselt dr. Csatáry László Lajos? Válasz: Akkor, amikor messziröl láttam, emlékszem, hogy olyan uniformist viselt, mint a magyar rendörök, olyan szürkéskék színüt, és csizmája is volt, úgy emlékszem. Nyomozó kérdése: Kitöl hallott dr. Csatáry László Lajosról, és mit hallott róla? Válasz: Csatáryról a többiektöl halottam, hogy ö az a vezetö rendör, akinek a téglagyár a gondjaira van bizva. Nyomozó kérdése: Az Ön tudomása szerint mi volt dr. Csatáry László Lajos foglalkozása? Válasz: Valami nagyon magas funkcionáriusnak kellett lennie, ha azért küldték Magyarországról, hogy itt kiírtsa a zsidókat. Nyomozó kérdése: Az Ön tudomása szerint milyen szerepet játszott dr. Csatáry László Lajos a gettóban és/vagy a téglagyári gyüjtötáborban? Válasz: Úgy, ahogy azt már mondtam, valószinüleg a legföbb parancsnok volt, és a gyüjtötábor az ö gondjaira volt bizva. Motorral járt, beszélgetett az örökkel, akik a tábort örizték a szögesdrót mögött, és utána elment. Nyomozó kérdése: Hallott Ön arról, hogy dr. Csatáry László Lajos bármilyen módon kegyetlenségeket követett el a város gettóban és/vagy a téglagyári gyüjtötáborban fogvatartott személyekkel szemben? Válasz: Nem tudom, de itt el szeretném mondani, esténként lövéseket hallottunk, de nem tudom kik és mire löttek. Az egyik nap reggel megtudtuk, hogy az osztálytársnömet Seiler Gizellát lelötték, ö volt az elsö áldozat, akiröl én tudok. Késöbb a többiektöl hallottam, hogy fennakadt a szögesdróton, és három napig ott hagyták, és csak utána temették el. Én már akkor nem voltam a gyüjtötáborban.". ${ }^{9}$

Az összesen nyolc oldal terjedelmü tanúvallomásból világosan kiderül, hogy SALAMON Edit, BALASSA Zoltán és mások által is a médiában megjelentetett újságcikk formájában közzétett saját visszaemlékezésével ellentétben nem emlékezett arra, hogy ki volt a téglagyári gettó parancsnoka. SALAMON Edit személyesen soha nem találkozott dr. CSATÁRY László Lajossal és csak messziről látott valakit, akiről másoktól azt hallotta, hogy ő dr. CSATÁRY László Lajos, a magas magyar funkcionárius, akit a ,zsidók kiirtására” küldtek Kassára. SALAMON Edit dr. CSATÁRY László Lajost mint föparancsnokot egyértelmủen összekeveri dr. HORVÁTH György kassai rendőr-fökapitány helyettes személyével. 
Vallomások és ellentmondások az 1947-1948-as dr. CSATÁRY László Lajos ellen lefolytatott kassai népbírósági eljárásban ${ }^{70}$

A kassai népbírósági eljárás jegyzőkönyve szerint dr. CSATÁRY László Lajos, mint volt magyar kassai rendőrkapitány SCHMUTZER József 1944 őszén történő bántalmazásában személyesen részt vett, míg más személyek, ŽUROVSKY Zoltán és SEMETKAY Mikuláš bántalmazásánál csak jelen volt, de azt semmilyen módon nem akadályozta meg, erre kísérletet sem tett.

SCHMUTZER József neve FRANKOVÁ Žofia tanúvallomásában a kassai népbírósági eljárás tárgyalási jegyzőkönyvében hangzott el: „Fenntartom az 1.6 szám alatt tett vallomásomat, és kiegészitem azzal, hogy minden alkalommal, amikor a völegényem megverve és sérülten hazajött, arra panaszkodott, hogy a vádlott nyersen és durván bánt vele, hogy a földre teperte és rugdosta és kínozta. Egy reggel jött egy nyomozó, aki azt mondta, hogy a vádlott parancsára le kell tartóztatnia a völegényemet, mert kommunista, és le is tartóztatta. Ahogy megtudtam a vádlott a legsúlyosabb börtönbe "toloncházba" záratta Magyarországon, ahonnan levelet is kaptam a völegényemtöl, melyben a vádlott nyersességére és durvaságára panaszkodott vele szemben. Arról, hogy a vádlott férfiakat vitetett el Košicéböl, onnan tudok, hogy amikor a völegényemet el-szállitották és kikísértem, láttam. A völegényem, amikor lefizette a vádlottat 2, vagy 3 esetben, akkor elengedte öt, de amikor nem tudott fizetni, elvitette öt."

Mivel a kapcsolatuk vőlegény-menyasszony volt, FRANKOVÁ valószínüleg elfogult lehetett. Vallomásában általános dolgokat említett, összefüggéstelenül, és sok esetben ellentmondásosan. Nem jelölt meg időpontot, hogy SCHMUTZER Józsefet mikor, hány alkalommal, mi alapján állították elő, politikai ügy, vagy kocsmai verekedés okán, esetenként hová „toloncol”-ták és dr. CSATÁRY László Lajos hogyan kínozta?

Az elmondottakból mindössze következtetni lehet arra, hogy ezek az események 1944. november hónapban, vagy azt követően történtek.

Nem életszerü, hogy SCHMUTZER József Magyarországon történő fogvatartása során — ha erre egyáltalán lehetősége lett volna —, levelezésében arra szentelt időt, és azzal foglakozott, hogy dr. CSATÁRY László Lajos milyen nyersen és durván bánt vele. FRANKOVÁ Žofia vallomása SCHMUTZER József elmondásai, a tanúnak való panaszkodásain és levelezéseken alapult, amelyek a több alkalommal történő elöállításait és ,deportálásait” követően hangzottak el.

A szlovák népbírósági anyagban utalás sem volt arra, hogy a tanú a birtokában lévő leveleket a hatóság számára bizonyítékként átadta, vagy bemutatta volna.

ŽUROVSKY Zoltán 1947-ben tett feljelentésében elhangzott, hogy 1944. XI. 4-én le akarta lőni dr. CSATÁRY László Lajost, de nem sikerült, majd három nappal később dr. CSATÁRY László Lajos emberei elfogták és a Gestapónál megkínozták.

A kassai népbírósági eljárás jegyzőkönyvében ŽUROVSKY Zoltán tanú vallomása így olvasható: „Csatáry Ladislavot 1943. évtől ismerem, akivel az Imperial Kávéházban ismerkedtem meg, ahol akkor dolgoztam, mint titkár. Nevezett hivatalból járt a kávéházba legalább hetente egyszer. 1944. évben, amikor a magyar hadseregtöl szabadságra jöttem, őrizetbe vette az édesanyámat, Žurovská Idát, mert zsidó származású volt, és a mai napig nem jött haza a koncentrációs táborból. Abban az időben, vagyis 1944. november 7. napján engem is örizetbe vetetett Csatáry, mivel merényletet akartam ellene elkövetni, hogy így álljak bosszút édesanyámért. A merénylet nem sikerült, mivel ezt nyilvános helyen akartam elkövetni Košicén a Štefániková utcán egy este, amiben a helyi lakosok megakadályoztak. A helyi lakosok feljelentése alapján, mint ahogy már említettem, 1944. november 7. napján elfogatott és más zsidó származásúakkal együtt Németországba vitetett. Az elfogás után Csatáry a német Gestapóra vitetett, ahol nagyon megkínoztak. A német gestapósok kínoztak, és Csatáry mindezek után eljött megnézni. Mivel a nyomozás során a Gestapó ellenem semmit nem talált, visszaadtak a magyar rendőrségre azzal, hogy másnap térjek vissza az alakulatomhoz, ami ellen Csatáry tiltakozott, hogy ne térjek vissza az alakulatomhoz, hanem szállítsanak Németországba, ami így is történt. Ehhez megjegyzem, hogy mikor őrizetben voltam a Varkolý nyomozói irodájában, Csatáry a következő megjegyzést tette: »Maga azt akarta, hogy meghaljak, de nagyon tévedett, mert ez fordítva fog megtörténni és maga lesz halott «." ${ }^{, 2}$ 
ŽUROVSKY Zoltán a kassai népbírósági eljárás tárgyalási jegyzőkönyvben rögzített tanúvallomásban nem említette dr. CSATÁRY László Lajos előtt történő bántalmazását. A vallomás hiteltelenségét támasztja alá, hogy dr. CSATÁRY László Lajos, mint rendőr segédfogalmazó a Magyar Királyi Rendőrség beosztottjaként egyáltalán nem rendelkezett parancskiadási és utasítási joggal a német Sondereinsatzkommando $(\mathrm{SD}=$ Speciális Osztag) vagy a Geheime Staatspolizei (Gestapo $=$ Titkos Államrendőrség) felett, valamint azok a tények és dokumentumok, amelyek azt bizonyítják, hogy dr. CSATÁRY László Lajos 1944 október végétöl már nem tartózkodott Kassán.

SEMETKAY Mikulaš tanúvallomása a kassai népbírósági eljárás tárgyalási jegyzőkönyvében: , Ez így ismétlödött mindig és 1944. 11. 2-án eljött a hivatalomba egy bizonyos Lipták nyomozó, aki azokkal a szavakkal, hogy Csatáry parancsára letartóztat. . . És ez után a Florianska utcába kerültem, ahol már Csatáry fogadott azokkal a szavakkal, hogy még nincs elökészitve az akta. Aztán elrendelte, hogy elvezessenek a mellettünk lévö helyiségbe, ahol engem minden ok nélkül kínoztak és vertek, hogy eszméletemet vesztettem. Utána sem hallgattak ki, de a szóban történö vallatások során annak ellenére, hogy többször kijelentettem a vádlottnak, hogy nincsenek nálam fegyverek és szórólapok, és ha megtalálja azokat nálam, elkobozhatja, semmi nem segitett, mert két nap multán parancsot adott, hogy az írásbeli parancs alapján deportáljanak Komáromba és onnan Németországba. ",73

A tanú vallomása szerint mindez nem dr. CSATÁRY László Lajos jelenlétében, hanem egy másik helyiségben történt. Arról a tanú egy szót sem szólt, hogy dr. CSATÁRY László Lajos bármire is utasította volna azokat, akik SEMETKAY Mikulašt elvezették a másik helyiségbe.

Honnan tudhatjuk, hogy ha egyáltalán megtörtént SEMETKAY Mikulaš bántalmazása, hogy azt kik, milyen indíttatásból követték el?

A tanúvallomás, csak egy dolgot bizonyít kétséget kizáróan, azt, hogy dr. CSATÁRY László Lajos SEMETKAY Mikulaš bántalmazásánál nem volt jelen, ha egyáltalán történt bárminemü bántalmazás.

Eugen BIDOVSZKI tanúvallomásának részlete a kassai népbírósági eljárás tárgyalási jegyzőkönyvéböl: „El voltam fogva a Flórán utcában. Azért fogtak el, mert németellenes voltam. 1944. november 2-tól november 5-ig tartottak itt. Hallottam, vagy mástól tudom, hogy két német tiszt társaságában azt nyilatkozta, hogy ezek itt mind kommunisták. Ezután mindenféle vizsgálat nél-kül elszállitottak Komáromba." "74

A tanú más személytől hallott dr. CSATÁRY László Lajosra utaló vallomása bizonyított tényként a szlovák ítélet indokolásában is megjelent.

A politikai jellegü deportálások Komárom irányába 1944 novemberét követően, SzÁLASI Ferenc miniszterelnöksége időszakában történtek. Dr. Karol NEMENY tanú a kassai népbírósági eljárás tárgyalási jegyzőkönyvben rögzített vallomásának részlete: „Még a magyar megszállás alatt 1939-ben az útlevélosztály fönöke volt, de politikai ügyeket is intézett, és konfliktusba kerültem vele, mert a Kassai Kerületi Bíróságon képviseltem politikailag üldözött személyeket. Mikor ezt Csatáry megtudta, szóvá tette, miért csinálom ezt, tudomás volt róla, hogy erös befolyása van, mert Horváth, ha valamit akart, abba a vádlott bármikor beleszólhatott. Biztos állhatott valaki mögötte, mert mikor Kassát megszállták a németek, megmutatkozott a teljhatalma. . . A feleségemtöl megtudtam, hogy a vádlott minden esetben a kihallgatás alatt álló személyeket kínzásnak vetette alá, és néha korbáccsal is ütött." 75

Dr. Karol NEMENY eskü alatt tett vallomásában kijelentette, hogy dr. CSATÁRY László Lajost már 1939-ben is ismerte, amikor a kassai rendörségen az útlevélosztály fönöke volt.

Dr. CSATÁRY László Lajos 1939-ben még diplomás munkanélküliként élt Szolnokon. A Magyar Királyi Rendőrség személyi állományába fogalmazógyakornokká, a kecskeméti rendőrkapitánysághoz 1940-ben nevezték ki és 1942 őszén került áthelyezésre Zomborról Kassára.

Fizikai lehetetlenség, hogy dr. CSATÁRY László Lajos 1939-ben a Kassai Rendőrkapitányság útlevélosztályának fónöke lett volna vagy, hogy egyáltalán a felvidéki városban tartózkodott.

A tanúvallomás tele van képtelenségekkel, feltételezésekkel, hamis állításokkal és dr. Karol NEMENY feleségtől hallott fikciókkal. Felmerül a kérdés, a feleség honnan tudta azokat, amiket állított.

Lényeges kérdésként merül fel továbbá dr. Karol NEMENY tanúvallomása alapján, hogy ki lehetett Kassa városában az általa már 1939-töl CSATÁRY nevü rendőrtisztként ismert személy, 
aki még dr. HORVÁTH György kassai rendőr-fökapitány helyettes felett is utasítási joggal rendelkezett.

Dr. Stefan KAIFER ${ }^{76}$ tanúvallomása dr. CSATÁRY László Lajosról a kassai népbírósági eljárás tárgyalási jegyzőkönyvében: „, Mivel ügyvédként müködtem, azt a meggyöződést alakitottam ki magamnak, hogy a vádlott a legvéreskezübb nyilas és mindenható úr volt, amennyiben a legmagasabb szinten teljhatalommal rendelkezett minden transzport fölött, és segitségére voltak német szervek, melyek egyenruhája számomra azonosithatatlan volt. Valamikor 1944 novemberében váratlanul letartóztattak és elszállitottak a Florianska utcába, ahol az ottani parancsnok, kemény módszerekkel bánt a fogvatartottakkal, és amikor 45-en voltunk egy helyiségben megjelent a vádlott egy gestapós kiséretében, és kijelentette, hogy közülünk mindenki kommunista. ",77

Kérdés, hogy a kialakult saját meggyőződés alapján hogyan lehet valaki véreskezü nyilas.

Ahogy a korbácsolás, úgy a „legmagasabb szinten teljhatalommal” való rendelkezés is olyan toposz, mint a „korbácsos gettóparancsnok”, ami több vallomásnál is felmerült. Ez is azt bizonyítja, hogy ezeket a vallomásokat elöre megírták, és hogy az eljárás koncepciós volt, amely nem a tényeken, hanem a „politika-csinálók” célkitüzésein alapult.

Dokumentumokkal bizonyított tény, hogy dr. CSATÁRY László Lajos 1944 novemberében már nem tartózkodott Kassán, azonban ha mégis valami csoda folytán ez úgy is történt volna, ahogyan azt dr. Stefan KAIFER állítja, annak kijelentése, hogy mások kommunisták, még nem lehetett háborús büntett.

A kassai népbírósági eljárás egyik „érdekessége”, hogy először dr. Stefan KAIFER ügyvédet akarták megbízni a távol lévő dr. CSATÁRY László Lajos védelmének ellátásával. ${ }^{78}$

\section{Dr. CSATÁRY László Lajos mint volt magyar kassai rendőrkapitány?}

2012-2013-ban a médiában megjelenő írásokban több alkalommal azt vetették fel, hogy dr. CSATÁRY László Lajos „volt magyar kassai rendőrkapitánynak” szerepe és felelőssége volt az 1944 novemberétől 1945. I. 18-ig tartó nyilas hatalom alatti időszakban történő különböző háborús és köztörvényes büncselekmények elkövetésében.

Dr. CSATÁRY László Lajost az 1948-as kassai népbírósági eljárásban, mint „,volt magyar kassai rendőrkapitány"-t nevezték meg, és a feljelentési, valamint tanúkihallgatási jegyzőkönyvekben mindig ilyen minőségében rögzítették.

Az 1944 novemberét követő időszakból is, mint négy jelentős esemény szereplőjeként, vagy részeseként került a média kereszttüzébe:

- DARABOS László, Kassa volt nyilas párvezetőjének 1958-ban az ellene indult kassai bírósági eljárása során elhangzott vallomásai ${ }^{79}$ szerint dr. CSATÁRY László Lajosnak tudomása és köze volt 1944 novemberében a Kassán 200-220 deportálásra váró zsidó személy gázzal történő elpusztításához;

- 1945. I. 5-én tizenkét katonaszökevény és partizángyanús személy felakasztása Kassa Fő utcáján;

- Egy kassai illetőségü tizenhét éves fiú 1945. I. 10-én történt jogtalan elfogása és koncentrációs táborba történő deportálása, ez utóbbi eset okán 2012 nyarán a kassai rendőrségen feljelentést is tettek dr. CSATÁRY László Lajos ellen;

- Kassa felszabadulása előtt két nappal, 1945. I. 17-én, a Ťahanovsky alagút mellett tizenhét embert lőttek agyon, és e tettekért dr. CSATÁRY László Lajosnak is viselni kell a felelősséget.

DARABOS László kassai volt nyilas pártvezető dr. CSATÁRY László Lajosra vonatkozó vallomása valóság tartalmával kapcsolatban a Budapesti Nyomozó Ügyészség által feltett kérdésekre dr. ZINNER Tibor történész professzor 2013. V. 22-én adott szakvéleményében a következőket fejtette ki: „, . . 2. Konkrétan a jelenlegi Magyarország területéröl tehervagonokkal deportált, 200-220 zsidó személy 1944 novemberében történt gázzal történö kivégzéséröl Darabos László által elöadottak mennyiben illeszthetöek az érintett korszak történészi eszközökkel feldolgozott forrásai közé? E kérdés megválaszolásához elözetesen konzultáltam a téma más szakértőivel, Salamon Pállal és Karsai Lászlóval, akik megerősitettek abban, hogy az általam ismert hazai s a nemzetközi szakirodalmon kívüli források, okmánygyüjtemények nem tartalmaznak adatot arra vonatkozóan, hogy akár Kassán vagy Kassa környékén, akár a történelmi Magyarország területén - az egyetlen szombathelyi esetet leszámitva - zsidók gázositására került volna sor. Ezen túlmenöen a rendelkezésre álló forrásokkal - igy a második világháború mene- 
tével és a Holokauszt kronológiájával is - egyértelmüen összeegyeztethetetlen, hogy 1944 novemberében négy vagonnyi Miskolcról érkezett zsidó deportálására egyáltalán sor kerülhetett. . E kérdés kapcsán is határozott álláspontom, hogy a Darabos László által elöadottak a histórikusak mind kronológiai, mind ténybeli, mind analógiai vizsgálati szempontból ellentétesek a rendelkezésre álló forrásokkal. "80

Kassa város rendőrkapitányságának vezetője 1943 öszétől 1945. I. 18-ig dr. HORVÁTH György rendőr-fökapitány helyettes volt.

Részlet a Budapesti Rendőr-főkapitányság Politikai Rendészeti Osztályon 1945. XII. 8-án készült dr. HORVÁTH György gyanúsított kihallgatási jegyzőkönyvéből: „1943. jan. 1-jén kineveztek fókapitány-helyettesnek Nagyváradon. A bevonulás idején kerültem 1940. szeptember 6-án Nagyváradra, és itt szolgáltam 1943. augusztus 31-ig. Innen kerültem Kassára, ahol a város kiüritéséig tartózkodtam, vagyis 1945 január 18-ig. "\$1

A Magyar Nemzeti Levéltárból került elő annak a tizenkét katonaszökevénynek nyilvánított személy felakasztásával kapcsolatban lefolytatott nyomozásnak az iratanyaga, ${ }^{82}$ amelyet a Magyar Királyi Rendőrség Kassai Rendőrkapitányságának vezetője dr. HORVÁTH György személyesen folytatott le és készítette el az erről szóló nyomozati jelentését 1945. I. 9-én.

A nyomozást a Magyar Királyi Főügyészség rendelte el a honvédelmi miniszter felhívására, mivel a bírósági ítélet nélkül kivégzett személyek mindegyike a honvédség személyi állományába tartozott.

A kivégzéseket GYARMATHY Gábor, Kassa főispánja hadmüveleti kormánybiztos, a Nemzetvezető SzÁLASI Ferenc szóbeli utasítására hivatkozó ítéletével rendelte el. Az akasztásokat a kassai német Sondereinsatzkommando ( $\mathrm{SD}=$ Speciális Osztag) alakulattól e célra kért és kapott német katona hajtotta végre 1945. I. 5-én. ${ }^{83}$

Az a tény, hogy az 1945. I. 5-én történt kivégzések nyomozását dr. HoRVÁTH György kassai rendőr-főkkapitány helyettes 1945. I. 9-én személyesen teljesítette, valamint a Magyar Nemzeti Levéltárban lévő 28 oldal terjedelmű irat tartalma egyértelmüen kizárja azt, hogy dr. CSATÁRY László Lajos Kassa rendőrkapitánya lett volna akár 1944. november hónapját megelőzően, vagy azt követően bármikor.

A dr. HORVÁTH György kassai rendőr-fökapitány helyettes elleni budapesti népbírósági eljárás irataiban dr. CSATÁRY László Lajos neve az 1944 októberét követő időszakra vonatkozó vallomásokban egyáltalán nem merült fel.

Ezek a bizonyítékok zárják ki továbbá egyértelmüen azt is, hogy dr. CSATÁRY László Lajosnak bármilyen köze lett volna a DARABOS László volt kassai nyilas pártvezető vallomásaiban említett, gázzal elpusztított 200-220 zsidó személyek, a tizenhét éves fiú 1945. I. 10-én Kassán történt elfogásához és deportálásához, valamint az 1945. I. 17-én, a Ťahanovsky alagút mellett elkövetett gyilkosságokhoz.

Dr. CSATÁRY László Lajos soha nem volt Kassa rendőrkapitánya, és az 1944. október hónapot követő időszakban Kassa városában bármilyen minőségben való jelenlétét is egyértelműen cáfolják a kutatások során előkerült dokumentumok, valamint történészi szakértői vélemények.

\section{A kassai népbírósági eljárásban lévö pontatlanságok, hibák, ellentmondások és jellegük, a bövebb részletezés mellözésével}

Részlet a Kassai Ügyészség vádindítványának magyar nyelvü fordításából: „Vádat emelek: Dr. Csatáry Ladislav ellen. Születési ideje: 1915. 03. 04. Mány (Magyarország), ismeretlen állampolgárságú, utolsó lakhelye: Košice, Moyzesova 19. szám, jelenleg ismeretlen helyen, rendőri tisztviselö, nőtlen, római katolikus, magyar nemzetiségü, vagyontalan, állítólag sértetlen, szabadlábon." 84

A vádemelés bevezetőjében dr. CSATÁRY László Lajos születési dátumaként 1915. III. 4et ${ }^{85}$ jelölték meg annak ellenére, hogy 1915. III. 5-én született.

Lakáscímeként Kassa, Moyzesova $19-$ et $^{86}$ adták meg, holott ő az Erdő utca 16. szám alatt lakott.

Nőtlen férfiként említik annak ellenére, hogy már házas emberként költözött 1942 őszén Kassára, ahol két gyermeke is született. A szlovák eljárásban készült jegyzőkönyvek mindegyike, mint volt magyar kassai rendőrkapitányt említi, holott legmagasabb beosztása rendőr segédfogalmazó volt. 
A Kassán lefolytatott népbírósági eljárásban maguk a hatóságok sem tudták meghatározni dr. CSATÁRY László Lajos rendőr segédfogalmazó beosztását, és mind a magyar, mind a szlovák eljárásban kihallgatott tanúk is egészen elképesztő és eltérő pozíciókba emelték.

Megemlítették, mint: csendőr századost, ENDRE László közvetlen alárendeltjét, gettóparancsnokot, hadnagyot a titkosrendőrségtől, kassai rendőrkapitányt, nyilas pártszolgálatost, rendőr hadnagyot, rendőr felügyelőt és táborparancsnokot.

„Korbácsos” személyét azonban mindegyikük precíz módon írta le és az elfogató parancs adatai szerint: $176 \mathrm{~cm}$ magas, gesztenyebarna hajú és szemöldökủ, sovány, gyenge testalkatú személy volt. ${ }^{87} \mathrm{~A}$ szemtanúk — még azok is, akik soha nem találkoztak vele — rendkívül kegyetlennek vallották.

Mindezekkel szemben a felkutatott dokumentumok szerint dr. CSATÁRY László Lajos 182$183 \mathrm{~cm}$ magas, szőke hajú és arányos testalkatú volt.

Az eljárás és az ítélet koncepciós voltát bizonyítja, hogy abban dr. CSATÁRY László Lajosra vonatkozóan olyan megállapítások hangzottak el, amely cselekményeket az 1945-1946-ban Budapesten lefolytatott népbírósági eljárásban bizonyítottan dr. HORVÁTH György volt kassai rendőr-fökapitány helyettes követett el. Továbbá olyan cselekményeket róttak dr. CSATÁRY László Lajos terhére, melyek megtörténtekor vagy még, vagy már nem tartózkodott Kassán.

\section{Dr. CSATARY László Lajos mint a deportálások szervezöje?}

Efraim ZUROFF feljelentésében nyomatékosan is kitért arra, hogy dr. CSATÁRY László Lajosnak személyesen volt köze a kassai zsidóság deportálásához, és tisztában volt azzal is, hogy milyen sors vár a koncentrációs táborokba hurcoltakra.

A levéltári kutatások során előkerült dokumentumokból azonban egyértelmúen kiderült, hogy a magyarországi zsidók 1944-ben történő deportálásának megszervezéséért, a gyűjtőtáborokból az ország határain kívülre, koncentrációs táborokba történő szállításukért és az ott bekövetkező halálukért JAROSS Andor belügyminiszter, ENDRE László belügyminisztériumi közigazgatási államtitkár, BAKY László belügyminisztériumi politikai államtitkár ${ }^{88}$ és FERENCZY László $^{89}$ csendőr alezredes - Adolf EICHMANN és a magyar rendvédelmi szervek közötti összekötö tiszt - voltak felelösök.

A Népbíróságok Országos Tanácsa ítéletei indokolása szerint mind a négy személy ismerte, elfogadta és támogatta, vagy legalábbis nem ellenezte Adolf EICHMANN tervét ${ }^{\mathbf{0}}$ a magyarországi zsidók országhatáron kívülre történő deportálásáról. A háborút követően Magyarországon a négy háborús föbünös ellen népbírósági eljárás indult, és az ügyükben hozott halálos ítéletet követően mindegyiküket kivégezték.

A Magyar Nemzeti Levéltárból kerültek elő a Népföügyészség 1946 augusztusában összeállított és több száz személy nevét tartalmazó kimutatásai, amelyekben a magyarországi háborús bủnösöket sorolták fel. A kimutatások kategóriákra osztva és indokolva sorolták a listára kerülés okait. ${ }^{91}$ repelt.

Dr. CSATÁRY László Lajos neve a Népföügyészég kimutatásainak egyik listáján sem sze-

\section{Dr. CSATÁRY László Lajos áthelyezése Kassáról Budapestre 1944 októberében}

Dr. CSATÁRY László Lajos beszélgetéseink során több alkalommal is megemlítette, hogy 1944 nyarán-öszén többször is kérvényezte dr. HORVÁTH György főkapitány helyettestől Kassáról történö áthelyezését. Miután dr. HORVÁTH György ennek nem tett eleget, ezért annak tudta nélkül, a szolgálati utat megkerülve intézte el áthelyezését Budapestre a HóDOSY Pál nyugállományú csendőr ezredes a Magyar Királyi Belügyminisztérium Rendőrfelügyelöje közvetlen alárendeltségébe tartozó, HENKEY János vezérkari ezredes által vezetett ellátó csoportba.

Dr. CSATÁRY László Lajos 1944 októberében Kassáról Budapestre történő áthelyezésének bizonyítékai: Dr. HORVÁTH György vádlott észrevételei a vádhoz: „, 4./ Csatáry Lászlót szorgalmas, puritán rendörtisztnek ismertem meg az alatt a félév alatt, amióta a kassai rendörkapitányságot vezettem s mivel a politikai elöadó személyében már három változás is történt, rajtam kivülálló okokból 1944 októberében hirtelen elhelyezték. "92

Dr. HORVÁTH György által előadottak bizonyítják dr. CSATÁRY László Lajos Kassáról Budapestre történő áthelyezése körülményeinek valós voltát. 
Dr. HORVÁTH György vallomásának azon kitétele, hogy „rajtam kívül álló okból” került sor az áthelyezésre is azt bizonyítja, hogy az a dr. CSATÁRY László Lajos által elmondottaknak megfelelően valósult meg 1944 októberében. A dr. HORVÁTH György elleni budapesti népbírósági eljárás anyagában — amely a vádlott háború végéig betöltött cselekményeit vizsgálta — dr. CSATÁRY László Lajos neve 1944 októberét követően a nyilas hatalom időszakában történő eseményekről készült egyik jegyzőkönyvben sem jelent meg, beleértve az 1945. I. 9-én dr. HORVÁTH György kassai rendőr-fökapitány helyettes által befejezett nyomozás iratait is, amely egyúttal azt is bizonyítja, hogy dr. CSATÁRY László Lajos ekkor már nem tartózkodott Kassán.

Dr. CSATÁRY László Lajos 1944. XI. 1-től HóDOSY Pál nyugállományú csendőr ezredes alá tartozó Magyar Királyi Rendőrség Rendőrfelügyelősége személyi állományában a HENKEY János vezérkari ezredes által vezetett ellátó csoportban tevékenykedett. ${ }^{93} \mathrm{Az}$ erre vonatkozó bizonyítékok szintén a levéltári kutatások során kerültek elő. A kassai rendőrkapitányság személyi állománya 1945. I. 18-án evakuált.

1944 őszén a szovjet csapatok már Magyarország területének egy részét elfoglalták. SzÁLASI Ferenc miniszterelnök 1944 decemberében elrendelte a rendőrség militarizálását annak érdekében, hogy ezeket az erőket szükség szerint a frontra vezényeljék. ${ }^{94}$

A rendelet megjelenését követően elkészült a Rendőrfelügyelöség beosztottjainak névsora függetlenül attól, hogy annak összeírásakor az egyes személyek éppen hol tartózkodtak. Dr. CSATÁRY László Lajos az összeírás időpontjában feladatai ellátása során Mosonmagyaróváron tartózkodott. A dokumentumban a 22. sorszám jelöli: ,,Csatáry László dr. s.fog. /Mmóváron összekötö tiszt a Henkey csop-nál//. ${ }^{95}$ (VII.sz. melléklet) tője. $^{96}$

HENKEY János vezérkari ezredes 1944. XI. 1-től 1945. III. 30-ig volt az ellátó csoport veze-

Dr. CSATÁRY László Lajos ennek az ellátó csoportnak volt összekötő tisztje 1944. XI. 1-től. Kassáról történő elhelyezésének tényét erősíti meg továbbá dr. MÉSZÁROS Győző 1994. XI. 15ei, a dr. CSATÁRY László Lajossal kapcsolatos kanadai eljárás során Budapesten készült magyar nyelvü tanúkihallgatási jegyzőkönyve is. Dr. MÉSZÁROS Győző 1944-ben Kassán rendőrségi segédfogalmazóként dr. CSATÁRY László Lajos kollégája volt. A jegyzőkönyv 3. oldalán olvasható többek között dr. CSATÁRY László Lajos korabeli személyleírása és az, hogy 1944 öszén már nem Kassán, hanem Mosonmagyaróváron tartózkodott. Részletek dr. MÉSZÁROS Győző tanúvallomásából: ,, . . - Kb. olyan magas volt mint én $(\mathrm{kb} .180 \mathrm{~cm})$, az egyenruhája jó volt rám, szökés volt . . - Amikor Óvárra kerülttem, oda már jöttek más kapitányságokról is. Ott találkoztam vele utoljára vagy 1944 végén." 97

A dokumentumok egyértelmúen bizonyítják, hogy dr. CSATÁRY László Lajos 1944. október végétől már nem tartózkodott Kassán. A magyar és szlovák sajtóban megjelenő írások, amelyek dr. CSATÁRY László Lajos 1944 őszétől 1945. I. 18-áig Kassán folytatott tevékenységét és az ezekkel kapcsolatos felelősségét vetik fel, nem felelnek meg a valóságnak.

\section{A Kanadai Királyi Szövetségi Rendörség (The Royal Canadian Mounted Police) 1993 és 1997 között végzett nemzetközi nyomozása dr. CSATÁRY László Lajos 1944-es kassai tevé- kenységére vonatkozóan}

A Kanadai Szövetségi Bíróság (The Federal Court of Canada) kezdeményezésére a Kanadai Királyi Szövetségi Rendőrség (The Royal Canadian Mounted Police) 1993 és 1997 között hat országra kiterjedő nemzetközi nyomozást folytatott dr. CSATÁRY László Lajos 1944-es kassai tevékenységével kapcsolatban. ${ }^{98}$ (VIII.sz. melléklet)

Beszerezték az 1945-1946-ban a dr. HORVÁTH György volt kassai rendőr-főkapitány helyettes háborús föbűnös ügyében lefolytatott budapesti népbírósági eljárás, valamint az 19471948-ban a dr. CSATÁRY László Lajos „volt magyar kassai rendőrkapitány” ellen a kassai népbíróság által lefolytatott népbírósági eljárások teljes iratanyagát. ${ }^{99}$

Tanúkihallgatásokat és fényképröl történő felismertetési eljárásokat végeztettek. Kanadában 18, az Amerikai Egyesült Államokban 4, Izraelben 2, Szlovéniában 1, Szlovákiában 2 és Magyarországon 2 tanút hallgattak ki. A 29 kihallgatott tanú közül az általánosan megfogalmazott és toposzokat is tartalmazó vallomásokon túl konkrét és bizonyító erejü vallomást egyikük sem tudott tenni dr. CSATÁRY László Lajosra.

Az eljárás során mindössze hét olyan személy akadt, aki személyleírást adott, és akik a fényképről történő felismertetési eljárás során vállalták, hogy azonosítják azt a személyt, aki sé- 
relmükre büncselekményt követett el. A felismertetési eljárást vállaló szemtanúknak nyolc fekete-fehér fotókból álló és több variációs sorrendben összeállított fotótablókat mutattak be, amelyek mindegyikén szerepelt dr. CSATÁRY László Lajos fényképe, és amelyek néhány évvel az 1944 utáni időszakot követően készült. (IX.sz. melléklet)

KISS Susan; kanadai lakos 1993. XI. 22-ei tanú kihallgatási jegyzőkönyvének részlete: „,ötét haj”. Öltözetét khaki színủ uniformisként írja le, amely a csendőrség ruházatának felel meg. A bemutatott fotók közül: ,a 2-es , vagy 3-as, vagy 4-es” számúu. ${ }^{100}$ (X.sz. melléklet.)

KISS Susan a fotók között nem tudta dr. CSATÁRY László Lajost azonosítani.

Judy LYSY kanadai lakos 1993. XI. 15-ei tanúkihallgatási jegyzőkönyv szerint a tanú úgy emlékezett, hogy dr. CSATÁRY László Lajos magas, huszonöt-harminc év közötti, sötét arcszínü volt. Judy LYSY a tablón szereplő személyek közül nem tudta dr. CSATÁRY László Lajost beazonosítani. ${ }^{101}$ (XI.sz. melléklet)

Dr. Stefan KAIFER; kassai lakos 1994. VII. 14-i Kassán készült tanúkihallgatási jegyzőkönyvében az szerepelt, hogy dr. Stefan KAIFER a bemutatott a fotókon szereplő személyek közül nem tudta dr. CSATÁRY László Lajost beazonosítani. ${ }^{102}$ (XII.sz. melléklet)

SAS Steve; kanadai lakos 1993. november 16-i tanúkihallgatási jegyzőkönyvének részlete: „Csatáry személyleirása? $180 \mathrm{~cm}$. magas, 60-70 kg., rövid sötét hajú.” SAS Steve az első találkozást dr. CSATÁRY László Lajossal 1940-re vagy 1941-re tette: „, The first time I saw Csatary was in 1940 or 41." SAS Steve nem találkozhatott dr. CSATÁRY László Lajossal az általa elöadott időpontban Kassán, mivel dr. CSATÁRY László Lajost csak 1940-ben nevezték ki fogalmazó gyakornoknak Kecskemétre, ahol 1941-ben minősítették át rendőrségi segédfogalmazóvá, majd onnan a délvidéki Zomborba helyezték át. Kérdésként merül fel ebben az esetben is, hogy ki volt a SAS Steve szüleinek boltjába már 1940, vagy 1941-ben rendszeresen bejáró, „CSATÁRY" nevü rendőrtisztként ismert személy Kassán?

SAS Steve a tablókon szereplő személyek közül nem tudta dr. CSATÁRY László Lajost beazonosítani. ${ }^{103}$ (XIII.sz. melléklet)

Georg Z. WASSERMANN USA lakos 1994. III. 29-ei tanúkihallgatási jegyzőkönyv részlete: „- Látja Csatáry Lászlót a fotón? - Azt hiszem az 5-ös, volt a bizonytalan válasz. Georg Z. WASSERMANN a fotókon szereplő személyek közül nem dr. CSATÁRY László Lajost azonosította be. ${ }^{104}$ (XIV.sz. melléklet)

Shachar YESHA'AYAHU az izraeli rendőrségen 1994. III. 9-én megtartott, fényképről történő felismerési eljárás jegyzőkönyve: „2-es, vagy a 3-as fotó Csatary.” , nyilatkozza a tanú. Shachar YESHA'AYAHU a fotókon szereplö személyek közül nem tudta azonosítani dr. CSATÁRY László Lajost. ${ }^{105}$ (XV.sz. mellkéklet)

\section{A felismertetési eljárások során egyik szemtanú sem azonosította dr. CSATÁRY László Lajost}

A személyleírást adó tanúk mind az 1947-1948-as kassai népbírósági eljárás során, mind az 1993 és 1997 között zajló kanadai eljárásban egy kb. 176 cm magasságú, rövid, gesztenyebarna hajú és szemöldökü, - SALAMON Edit emlékei szerint szemüveges -, vékony egyenes orrú, karcsú, gyenge testalkatú, khaki színủ dzsekit, khaki színű bricsesz nadrágot és hosszúszárú fekete csizmát viselő személyre emlékeztek.

A tanúk által leírt férfi alakja, arca, ruházata vélhetően mindegyikük emlékezetébe jól bele vésődhetett, mert az őket ért traumát követően még ötven évvel később, 1993-1994-ben is ezt a személyt írták le. Ez a személyleírás, azonban merőben eltér dr. CSATÁRY László Lajos korabeli kinézetétől. Ha a jogsértések az adott időszakban megtörténtek, azokat valamely más személy, de nem dr. CSATÁRY László Lajos követte el.

A valóságost megközelítő személyleírást dr. MÉsZÁROS Győző budapesti lakos, volt kassai rendőr segédfogalmazó, dr. CSATÁRY László Lajos kassai kollégája adja az 1994. XI. 15-én a Kanadai Királyi Szövetségi Rendőrség (Royal Canadian Mounted Police) és a Magyar Legfőbb Ügyészség által Budapesten felvett tanúvallomási jegyzőkönyve 3. oldalán olvasható. ${ }^{106}$

A kanadai eljárás során a tanúktól felvett jegyzőkönyvek egyértelműen arra adnak bizonyítékot, hogy egy olyan személyről van szó, aki már 1939-től Kassán tartózkodott, és a KISs Susan tanú által leírt ruházata ${ }^{107}$ alapján valószínüsíthetően a csendörség kötelékében teljesített szolgálatot.

Azokat a tényeket, hogy nem dr. CSATÁRY László Lajos személyéről van szó, döntő mértékben támasztja még alá dr. Karol NEMENY és SAS Steve tanúvallomása: 
- Dr. Karol NEMENY az 1948-as kassai eljárás során eskü alatt tett vallomásában a dr. CSATÁRY László Lajossal történő találkozását 1939-ben határozta meg.

- SAS Steve 1993-ban a Kanadában indult eljárás során tett tanúvallomásában dr. CSATÁRY László Lajossal történő első találkozásukat 1940. vagy 1941. évben jelölte meg.

Mind a budapesti népbíróság 1946. évben lefolytatott, mind a kassai népbíróság 1948-ban lefolytatott eljárásai, valamint a Kanadai Királyi Szövetségi Rendőrség (Royal Canadian Mounted Police) 1993 és 1997 között végzett nyomozása során, a kihallgatott tanúk olyan általuk ismert személyről tettek vallomást, aki már 1939-től egészen 1945. I. 18-ig Kassán tartózkodott. Ez a személy azonban nem azonos dr. CSATÁRY László Lajossal. ${ }^{108}$

A Kanadai Királyi Szövetségi Rendőrség (Royal Canadian Mounted Police) a négy évig tartó nemzetközi nyomozás során dr. CSATÁRY László Lajos személyére vonatkozóan nem állapított meg háborús büntettre utaló cselekményt, ezért a vele kapcsolatos eljárásban hivatalos megszólítására sem gyanúsított, sem tanú minőségében nem került sor.

\section{Miért nem járt eredménnyel a kassai népbíróság által kiadott letartóztatási parancs?}

A dr. CSATÁRY László Lajos ellen kibocsájtott elfogatási parancsot 1948. III. 16-án adta ki a kassai népbíróság. ${ }^{109}$

Dr. CSATÁRY László Lajos ebben az időszakban még Európában, a bejelentő igazoláson is feltüntetett adataival, családjával együtt Németországban Simbach am Inn városban tartózkodott. ${ }^{110}$ Németországból 1949-ben vándoroltak ki Kanadába.

A háborút követő időszakban a szövetséges győztes hatalmak katonai és polgári nyomozói folyamatosan járták azokat a területeket, ahol a vesztes fél háborús büncselekményekkel gyanúsítható rendvédelmi múltú, vagy civil polgárai akár álnéven is bujkálhattak.

A dr. CSATÁRY László Lajos nevével, de az elkövetett büncselekmények miatt kőrözött személy leírásával kiadott elfogató parancs azonban sem személyi adataival, sem dr. CSATÁRY László Lajos valós személyleírásával semmilyen formában nem mutattak egyezőséget. Jellemző eset, amikor dr. CSATÁRY László Lajos 1948. XI. 1-én megjelent az USA zóna katonai parancsnokságán a németországi Altötting városában. Már Münchenben laktak, amikor 1948 öszén tudomására jutott, hogy neki tulajdonítják tizenkét ember felakasztását 1945. január elején Kassa Fő utcáján. A hír megrendítette és felháborította. Úgy döntött, hogy ezt a képtelenséget tisztázni kell. A család nem akarta elengedni. Attól tartottak, hogy soha nem tér vissza. A becsület azonban többet ért, és dr. CSATÁRY László Lajos gyalog vágott neki a München-Altötting útnak. 1948. XI. 1-én este, zuhogó esőben érkezett az amerikai zóna katonai parancsnokságára, ahol bejelentkezett azzal, hogy ezt a tudomására jutott kassai ügyet tisztázzák le.

A katonai nyomozóknak átadta azt az okmányt, amely szerint őt 1944. XI. 1-ei hatállyal Budapestre a Magyar Királyi Belügyminisztériumba helyezték át. A vizsgálat során az Osztrák Köztársaság Salzburg városában székelő amerikai katonai parancsnokság bevonásával tisztázták a kérdést, majd amikor útjára engedték közölték vele, mehet bárhová, akár az Egyesült Államokba is.

A II. világháborút követően a háborús bünösök bírósági perei 1949-ig tartottak. Az Amerikai Egyesült Államok és a győztes hatalmak 1948-ban nem voltak „barátkozós” hangulatban a világháború veszteseivel. Kevés a valószínúsége annak, hogy az USA katonai nyomozói elengedték volna dr. CSATÁRY László Lajost, ha a legkisebb gyanúja is felmerült volna annak, hogy Kassán vagy bárhol elkövetője, részese lett volna háborús büncselekményeknek, gyilkosságoknak.

Dr. CSATÁRY László Lajos vétlenségét támasztja alá a németországi Simbach am Inn városban székelő magyar iroda vezetője FÜZESY István által 1949. V. 6-án kiadott igazolvány is. Az igazolvány tanúsítja, hogy az Amerikai Egyesült Államok katonai hatóságai dr. CSATÁRY László Lajos háború során folytatott tevékenységét lenyomozták, valamint azt is, hogy nem állt szándékukban őt a keleti zónában, illetve Magyarországon folyó koncepciós perek áldozatául dobni. ${ }^{111}$ (XVII.sz. melléklet)

\section{Eljárási és kriminalisztikai anomáliák a budapesti és a kassai népbírósági eljárások során}

\section{Gyors lefolyású népbírósági eljárások}


A budapesti népbírósági eljárás során a budapesti Politikai Rendészeti Osztályon történő kihallgatások 15 nap alatt valósultak meg, mely alatt 18 föt hallgattak ki. Maga a népbírósági eljárás pedig négy nap alatt zajlott le, ahol 33 tanút hallgattak meg. ${ }^{112}$

A kassai népbírósági eljárás keretében a kassai politikai rendőrségen két nap alatt tíz személyt hallgattak ki. A kassai népbírósági tárgyalás egy nap alatt valósult meg, ahol tíz perces tanácskozást követően a vádlottat távollétében — jogorvoslati lehetőség nélkül — kötél általi halálra, továbbá vagyonelkobzásra ítélték. ${ }^{113}$

A rövid idő alatt lefolytatott népbírósági eljárás irataiból világosan látható, hogy a vallomások értékelésével a kassai népbíróság egyáltalán nem foglalkozott.

Mindkét népbírósági eljárás súlyos kriminalisztikai hibája volt, hogy a dr. CSATÁRY Lászlónak vélt, illetve a valódi dr. CSATÁRY László Lajos személyazonossága között fennálló ellentmondásokat nem oldották fel és erre vonatozóan még kísérlet sem történt.

A budapesti és a kassai népbíróságok által kontroll nélkül elfogadott tanúvallomások és a jogerős ítéletekkel befejezett eljárások tették többek között lehetővé, hogy dr. CSATÁRY László Lajost a Budapesti Nyomozó Ügyészségen 2011. IX. 21-én az Efraim ZUROFF által tett büntető feljelentéssel ismételten „tettesévé” tegyék az 1941-1945 közötti Kassán elkövetett háborús büncselekményeknek.

\section{A fiktív és a valódi dr. CSATÁRY László Lajos}

A dr. HORVÁTH György ellen lefolytatott budapesti népbírósági eljárás iratainak tanulmányozása során feltünő volt, hogy sem a rendőri jelentések, sem a tanúktól felvett jegyzőkönyvek, sem más iratok között egy sem volt, amelyikben szerepelt volna dr. CSATÁRY László Lajos személyleírása. ${ }^{114}$

Ennek oka, hogy a kassai volt rendőr kollégáktól helytelen módón sem a korabeli nyomozó hatóság, sem a bíróság nem kért személyleírást. Ugyancsak eljárási hiba volt, hogy azok a személyek, akik a deportálást és a koncentrációs tábort túlélve vallomást tettek, az őket bántalmazó, megkínzó és deportáló személyről sem a rendőrség, sem a bíróság nem kért és a tanúk sem adtak személyleírást.

Különös, hogy a nyomozást lefolytató hatóság erre a lényeges kérdésre vonatkozóan nem hallgatta ki öket, illetve a Népbíróság sem figyelt fel erre a súlyos kriminalisztikai hibára, és arra sem, hogy BALKÁNYI Sándor, valamint WEISZER Rózsi és még néhány tanú egymással és, vagy önmagukkal szemben is milyen súlyos és feloldhatatlan ellentmondásokba keveredtek.

A rendőri jelentések és jegyzőkönyvek, valamint a népbíróságokon tett vallomások olvasásakor úgy tủnt, hogy ez a lényeges momentum egyáltalán nem volt szempont.

Dr. CSATÁRY László Lajos kassai tevékenységének megismerésére a budapesti Politikai Rendészeti Osztály nyomozójának volt ugyan egy kísérlete arra, hogy eljárjanak a Csehszlovák követségen a kassai hatóságok irányába, azonban az erről készült jelentésnél több nem történt. ${ }^{115}$

Többek között ezek az eljárási hibák is erősítik azt, hogy a Budapesten dr. HORVÁTH György volt kassai rendőr-fökapitány helyettes ellen lefolytatott népbírósági eljárás részben koncepcióra épült, és amely érintette dr. CSATÁRY László Lajost is, aki azonban nem volt jelen, ezért a személyét érintő vádakat megcáfolni nem tudta. A vallomást tevő túlélő szemtanúk dr. CSATÁRY László Lajost nem láthatták, így nem is azonosíthatták. Valójában senki sem tudta, hogy kire teszik terhelő vallomásaikat. ${ }^{116}$

A koncepciós jellegre és az elvárások teljesítésére utal többek között KASSAI-FARKAS Ibolya volt kassai rendőrségi tisztviselö dr. CSATÁRY László Lajosra vonatkozó vallomásrészlete: „A gettó dolog értelmi szerzöje Csatáry volt."117

A kassai népbírósági eljárás során a budapestivel ellentétben, a tanúk már adtak személyleírást arról az általuk már 1939 óta dr. CSATÁRY László Lajosként ismert, vagy említett „,volt magyar kassai rendőrkapitányról”, aki 1941 és 1945 között a különbözö büncselekményeket sérelmükre elkövette. Ebben az eljárásban súlyos hiba volt, hogy nem tisztázták dr. CSATÁRY László Lajos személyi adatait, személyleírását, holott az 1943 augusztusában Kassán kiállított útlevelének a helyi rendőrségi irattárban maradó adatlapján lévő fotó alapján az azonosítást megtehették volna.

Nem tisztázták továbbá családi állapotát, lakóhelyének címét, a kassai rendőrségen betöltött státuszát, beosztását sem. Ugyancsak nem tisztázták Kassán való tartózkodásának idejét 
sem. Így azok a szemtanúk, mint például dr. Stefan KAIFER, vagy SAS Steve akiknek vallomása szerint a dr. CSATÁRY-nak ismert személlyel, mint a „kassai rendőrség útlevél osztályának vezetőjével" már 1939-1940-1941-ben találkoztak, és aki 1944 novemberében KAIFERT személyesen hallgatta ki. Azok az 1944 tavaszi deportálásokat elszenvedő túlélők, akik „korbácsos és embereket kínozó" személyére emlékeztek és az 1944 októberétől 1945. I. 18-ig elkövetett háborús büncselekmények túlélőinek mindegyike, vagy mint például ŽUROVSKY Zoltán, akit „1944. november 4-én a dr. CSATÁRY ellen elkövetett merénylete” miatt tartóztatott le, mindannyian egy és azonos személyre, de egyértelmúen nem dr. CSATÁRY László Lajosra vonatkozóan tették meg terhelö tanúvallomásukat.

A kassai népbíróság eljárásának anyagából — benne a dr. CSATÁRY László Lajos ellen hozott itéletből és annak indokolásából - egyértelmüen kitünik, hogy sem a rendőrségi, sem az ügyészségi, sem a bírósági eljárás során egyáltalán nem foglakoztak azzal, hogy tisztázzák, ki volt a jogsértések valódi elkövetője, pusztán az volt a cél, hogy egy fiktív személy nevet kapjon és az elvárásoknak megfelelően halálos ítélet kiszabására kerüljön sor.

Külön figyelmet érdemel az a tény, hogy a kassai népbírósági eljárás során az 1947-1948ban a dr. CSATÁRY László Lajos volt magyar kassai rendörkapitány ellen lefolytatott eljárásban, az 1945-1946-ban a dr. HORVÁTH György „háborús föbünös”, volt magyar kassai rendőr-fökapitány helyettes ellen lefolytatott budapesti népbírósági eljárás iratainak megtekintésére, az abban rögzített gyanúsítotti és tanúkihallgatási jegyzőkönyvek tanulmányozására a kassai hatóságok még kísérlet sem tettek, holott a háborús bünösök ellen indított bírósági eljárások mindenütt nagy figyelmet kaptak és amelyekről a korabeli sajtó is kiemelten tudósított. $^{118}$

\section{A napjainkig is kiható kriminalisztikai hibák a dr. CSATÁRY László Lajossal kapcsolatos eljárásokban}

A kassai népbíróság a rendőrség, illetve az ügyészség által rendelkezésére bocsátott adatok, valamint a tanúk által megadott személyleírás alapján 1948. III. 16-án a elfogató parancsot adott ki „dr. Ladislav /László/ Csatáry” ellen. A letartóztatási parancs főbb adatai szerint dr. CsATÁRY László Lajos született Mány 1915. III. 4-én, magassága: $176 \mathrm{~cm}$, haja színe és szemöldöke gesztenyebarna, testalkata: sovány és gyenge, orra: vékony, egyenes volt. ${ }^{119}$ (XVIII.sz. melléklet)

A letartóztatási parancs tartalma nem felelt meg dr. CSATÁRY László Lajos korabeli valós személyi adatainak, személyleírásának, és amely hibákat, lényeges eltéréseket különböző dokumentumok, dr. CSATÁRY László Lajos személyi okmányai, valamint a róla készült korabeli fotók támasztanak alá.

A letartóztatási parancsban kiadott személyleírást összevetve a dr. CSATÁRY László Lajos tulajdonát képező személyi okmányokkal és fényképekkel, a korabeli nyomozó hatóságok által elkövetett súlyos kriminalisztikai hibákra és következményeire, egy több mint hetven éven keresztül feltáratlan és megdöbbentő hibasorozatra derült fény.

A dr. CSATÁRY László Lajos számára 1943. VIII. 24-én a kassai rendőrkapitányság által kiállított útlevelében elhelyezett fényképen egy ovális arcú, magas homlokú férfi látható. ${ }^{\mathbf{1 2 0}}$ (XIX.sz. melléklet)

Az útlevélben rögzített személyi adatok szerint 1915. III. 5-én született és a személyleírást is tartalmazó rész pedig egy magas és szőke hajú férfit ír le. ${ }^{121}$ (XX.sz. melléklet)

A Dr. csizsik-CSATÁRY Ladislaus számára 1948-ban Münchenben kiállított német személyi igazolvány azonban pontosan adja meg testmagasságát, amely $182 \mathrm{~cm} .{ }^{122}$ (XXI.sz. melléklet)

A népbírósági eljárásokban terhelő vallomásokat tevő tanúk által adott személyleírás szerint dr. CSATÁRY László Lajos vékony, gyenge testalkatú volt.

A „Magyar Királyi Rendőrség Szervezete és Ügyvitele” címü kiadvány egyértelmü kritériumként határozza meg a fogalmazói karban való alkalmazás egyik alapvető, a testalkatra vonatkozó kellékét. ${ }^{123}$ (XXII.sz.melléklet)

A dr. CSATÁRY László Lajosról készült korabeli fotók egyértelműen bizonyítják, hogy testalkata erős volt, termete pedig magas, tehát az elöírás 3. pontjának maximálisan megfelelt. Dr. CSATÁRY László Lajos rendőrségi segédfogalmazó a képek jobb oldalán látható. A rendőrökkel együtt készült fotón jól látható, hogy majd egy fejjel magasodik ki a többiek közül. ${ }^{\mathbf{1 2 4}}$ (XXIII.sz. melléklet) 
A tanúk által leírt és a letartóztatási parancs személyleírásban szereplő $176 \mathrm{~cm}$ magasságú, rövid, gesztenyebarna hajú és gesztenyebarna szemöldökü, karcsú, gyenge testalkatú, khaki színü egyenruhát, bricsesz nadrágot és fekete csizmát viselö személyleírású féri tehát nem azonos dr. CSATÁRY László Lajossal.

\section{A törvényes vádemelés feltételei}

A büntetőeljárás eredményes befejezéséhez feltétlenül szükséges az, hogy:

- a törvény büntetni rendelje a dolog, vagy személy ellen elkövetett tettet, vagy mulasztást, amelyet;

- valahol, valamikor, valahogyan, valamivel;

- egy büntethető személy;

- szándékosan vagy gondatlanul valamilyen okból elkövetett.

Amennyiben e négy szükséges elem közül valamelyik nem valósul meg, abban az esetben törvényesen vádat emelni nem lehet.

Dr. CSATÁRY László Lajossal kapcsolatosan, illetve az ellene indított eljárások esetében több tényállási elem sem valósult meg.

Néhány példa a teljesség igénye nélkül:

- A budapesti népbíróságon háborús büntett miatt, míg a kassai népbíróságon kollaboráció és fasiszta megszállás ${ }^{125}$ büncselekménye, illetve olyan jogsértések miatt indultak eljárások szándékosan elkövetett cselekmények okán, amelyek sértették a hatályos törvényeket, vagyis a jogi tárgy bizonyíthatóan sérült. A deportálásokkal, a kegyetlenkedésekkel, a koncentrációs táborokba való szállításokkal a tevéssel elkövetett magatartás is megvalósult.

- A tanúk az elkövető személyében egy bizonyos dr. CSATÁRY László néven ismert férfit jelölnek meg, mint aki sérelmükre a büncselekményeket elkövette. Azonban a budapesti, valamint a kassai nyomozó hatóságok és a népbíróságok elmulasztották tisztázni, azonosítani az elkövető személyét, személyleírását kontroll nélkül bizonyítékként értékelték úgy, hogy a tanúk szerint a dr. CSATÁRY-ként emlegetett személy volt az elkövetö.

- A korabeli eljárásokban nem kerültek tisztázásra az egyes büncselekmények elkövetési körülményei sem, és így fordulhatott elő például az, hogy a két országban két év különbséggel lefolytatott népbírósági eljárásokban rögzített vallomások szerint a téglagyári táborból való szökések megakadályozása céljából a fegyverhasználatra kiadott parancsot a budapesti népbírósági eljárásban dr. HORVÁTH György volt kassai rendőrkapitány helyettes, míg a kassai népbírósági eljárásban pedig dr. CSATÁRY László volt magyar kassai rendőrkaptány adta ki.

- Nem került tisztázásra a vagonablak kivágás megtiltására vonatkozó jogsértő magatartás sem, amelynek lényeges eleme és ellentmondása, hogy maga a cselekmény meg sem valósult, vagyis nem történt meg a büncselekmény. Ezt a tényállási elemet már a dr. HORVÁTH György elleni budapesti népbírósági tárgyaláson BALKÁNYI Sándor önmagával ellentmondó tanúvallomásai alapján tisztázni lehetett volna. A példából látható, hogy sem a jogi-, sem az elkövetési tárgy nem sérült, mivel azok meg sem jelentek.

- Az egyes túlélő szemtanúk vallomásai alapján részben megvalósult az elkövetési magatartás és annak eredménye is. Az alannyá válás és a bünösség feltételei azonban nem jelennek meg, mert a bizonyítékok azt támasztják alá, hogy a jogsértéseket nem dr. CSATÁRY László Lajos követte el.

- A büntető eljárások során az elkövető személyének és a bünösség tisztázására még kísérlet sem történt.

Összességében megállapítható, hogy a törvényes vádemeléshez szükséges négy tényállási elem feltételei közül mindössze kettő valósult meg.

\section{Három tény és három kérdés}

A dr. CSATÁRY László Lajos ügy három jól elkülöníthető időszak történéseire tagozódik, de ezeket egy egységben kell kezelni. 
Első időszak: 1941. július-augusztus. A Kassa és Kassa környéki zsidók Kamenyec-Podolszkij-ba történő deportálása.

Második időszak: 1944. április-május-június. A Kassa és Kassa környéki zsidók gettóba, majd a kassai téglagyárba történő koncentrálása és ezt követően Auschwitzba való deportálása.

Harmadik időszak: 1944. október vége és 1945. I. 18. között. A nyilas hatalom időszakában Kassán elkövetett jogsértések.

\section{Az elsö időszak és tényei}

A vádak szerint 1941. július-augusztusban dr. CSATÁRY László Lajos 300 kassai és Kassa környéki zsidó személyt deportál Kamenyec-Podolszkíj-ba, ahol többségüket kivégezték. Karol NEMENY a kassai népbíróságon 1948-ban eskü alatt tett vallomása szerint első találkozása dr. CSATÁRY László Lajossal 1939-ben történt, amikor a kassai rendőrség útlevél osztályának a vezetője volt.

SAS Steve a Kanadai Szövetségi Bíróság (The Federal Court of Canada) által 1993-ban kezdeményezett vizsgálata során a dr. CSATÁRY László Lajossal történt első találkozását 19401941-re datálja.

Efraim ZUROFF azzal egészítette ki 2011 szeptemberében tett feljelentését, hogy dr. CSATÁRY László Lajos 1941-ben — az Ausztráliában élő WEINBERGER Marika elmondása sze-rint az édesapjától hallottak alapján — deportáltatta Kamenyec-Podolszkijba WEINBERGER Ma-rika rokonait. Efraim ZUROFF feljelentésének ez utóbbival történő kiegészítését Karol NEMENY dr. CSATÁRY László Lajossal kapcsolatos 1939-re utaló vallomásában elhangzottakra is alapozhatta.

Dokumentumokkal bizonyított tények támasztják alá, hogy dr. CSATÁRY László Lajos az inkriminált időszakban még nem tartózkodott Kassán.

\section{A második időszak és tényei}

A vádak szerint 1944 áprilisa és júniusa között a Kassán létrehozott téglagyári gyüjtőtáborból dr. CSATÁRY László Lajos gettóparancsnok kegyetlenkedéseivel és aktív közremüködésével 15700 zsidó személy koncentrációs táborokba küldésére került sor, ahol dr. CSATÁRY László Lajos tudtával is olyan körülmények közé kerültek, amely életüket veszélyeztette, és többségük halálát okozta.

Az inkriminált időszakkal kapcsolatos korabeli magyar és szlovák népbírósági eljárások során kihallgatott tanúk hamis, vagy jobb esetben tévedéseken alapuló valótlan és egymásnak is ellentmondó vallomásai alapján a büncselekmények vagy meg sem valósultak, vagy ha megtörténtek, azokat nem dr. CSATÁRY László Lajos követte el.

A Kanadai Szövetségi Bíróság (Federal Court of Canada) iratanyagában található huszonkilenc tanú kihallgatási jegyzőkönyveiben egy dr. CSATÁRY László Lajos nevü személyre vonatkozó, többségükben általánosságokat és toposzokat is tartalmazó vallomások olvashatók. A felismertetési eljárásra is alkalmasnak minősülő hét szemtanú egyike sem azonosította dr. CSATÁRY László Lajost.

Levéltári dokumentumokkal bizonyított tény, hogy az 1944-es magyarországi deportálásokért felelős háborús bünösök személye megállapítást nyert, és bírósági úton történő felelősségre vonásuk 1945 és 1949 között megtörtént.

\section{A harmadik idöszak és tényei}

A vádak szerint 1944 novembere és 1945. I. 18. közötti időben dr. CSATÁRY László Lajos, mint Kassa rendőrkapitánya felelős a nyilas hatalom időszakában deportált vagy kivégzett több száz zsidó, illetve baloldali gondolkodású személy sorsáért, az 1945. I. 5-én tizenkét személy felakasztásáért, 1945. I. 10-én egy tizenhét éves fiú elfogásáért, koncentrációs táborba való deportálásáért, valamint 1945. I. 17-én további tizenhét fő kivégzéséért.

Dokumentumokkal bizonyított tény, hogy dr. CSATÁRY László Lajos rendőr segédfogalmazó soha nem volt Kassa rendőrkapitánya, az elkövetett büncselekményeket nem ö követte el, mivel abban az időszakban már nem tartózkodott Kassán.

\section{A dr. CSATÁRY László-ügy szempontjából felmerülö három sarkalatos kérdés}


Ha dr. CSATÁRY László Lajos:

- 1939-1941-ben még nem tartózkodott Kassán, és ha az;

- 1944-ben végrehajtott deportálások során a kegyetlenkedések elkövetőjeként dr. CSATÁRY

László Lajos egyetlen eljárásban egyetlen szemtanú sem azonosította, illetve felelössége sem volt több ezer ember deportálásában, és ha;

- 1944 októberét követően már nem tartózkodott Kassán, akkor ki volt az a dr. CSATÁRY László Lajosként ismert személy, aki az 1941-1945 között terjedö időszakban a háborús büncselekményeket Kassán elkövette?

Ezekre a több mint 70 éve megválaszolatlan kérdésekre az idő múltával igen nehéz válaszokat adni, ám a kutatott iratokban, dokumentumokban két potenciális név is felmerül. Két olyan személy neve, akik közül az egyik, a Magyar Királysághoz visszacsatolt Kassa első számú rendőri vezetője volt; dr. HORVÁTH György vidéki rendör-fökapitány helyettes, és akinek az internáltakkal szembeni viselkedéséről a téglagyári tábor belső zsidó őrség vezetője dr. SzÁsz Elemér tanúvallomásában olvasható. ${ }^{\mathbf{2 6}}$

A másik személy Szoó Tibor a kassai rendőrkapitányság felügyelőgyakornoka, akinek nevét és internáló táborparancsnoki beosztását dr. HORVÁTH György volt kassai vidéki rendőrfőkkapitány helyettes, valamint dr. SzÁsz Elemér tanúvallomása ${ }^{127}$ bizonyítja, és amit egyértelmúen erősít meg a jeruzsálemi Jad Vasem intézet kutatási anyaga is.

\section{A Kanadai Szövetségi Bíróság (Federal Court of Canada) „Ladislaus Csizsik-CSATARY” dosz- sziéja}

A Kanadai Szövetségi Bíróság (Federal Court of Canada) ügyirata ${ }^{\mathbf{2 2}}$ nem tartalmaz olyan releváns adatokat, amelyek befolyásolták volna a budapesti népbíróság és a kassai népbíróság peres irataiban, ${ }^{129}$ valamint közkönyvtárakban és dr. CSATÁRY László Lajos magándokumentumai kutatása során előkerülő, és vétlenségét bizonyító tényeket, inkább megerősítik és alátámasztják azokat, különös tekintettel a túlélő tanúk vallomásaira és a fényképről történő eredménytelen személyfelismertetési eljárási jegyzőkönyvekre.

A Kanadai Királyi Szövetségi Rendőrség (Royal Canadian Mounted Police) által lefolytatott nemzetközi nyomozás öt kötetből álló dossziéjának irataiból megdöbbentő módon derül ki az, hogy a Budapesten 2011. IX. 21-én a dr. CSATÁRY László Lajos ellen, háborús büncselekmények miatt tett büntető feljelentésben foglaltak pontosan megegyeznek azokkal a nyomozás tárgyát képező körülményekkel, amelyek miatt 1993-ban a kanadai hatóságok a hat országra kiterjedő vizsgálatot megkezdték, és amelynek eredményeképpen azt 1997-ben dr. CSATÁRY László Lajos vétlenségének megállapítása okán zártak le.

Az 1993 és 1997 között lefolytatott nyomozás adatai és dokumentumai önmagukban is kétséget kizáróan bizonyítják azt, hogy dr. CSATÁRY László Lajos nem azonos azzal a személlyel, aki 1939 és 1945 közötti időszakban az első bécsi döntéssel a Magyarországhoz visszacsatolt Kassán tartózkodott és az ott élő, illetve a Kassa környéki zsidóság sérelmére a háborús bủncselekményeket elkövette.

Nem valószínủ az, hogy ha a Kanadai Szövetségi Bíróság (Federal Court of Canada) és a Kanadai Királyi Szövetségi Rendőrség (Royal Canadian Mounted Police) az eljárás során dr. CSATÁRY László Lajos ügyében háborús, vagy bármilyen más büncselekményt állapít meg, abban az esetben elmulasztották volna a bírósági úton történő felelősségre vonását.

A nyomozás befejezését követően dr. CSATÁRY László Lajos ellen Kanadában nem indult eljárás és 1997-ben Kanadából már magyar állampolgárként, magyar okmányokkal települt át Magyarországra.

A Kanadai Igazságügyi Minisztérium (Department of Justice Canada) 2015. IV. 13-án kelt tájékoztató levele szerint nem tudják, hogy mi motiválta dr. CSATÁRY Lászlót kanadai állampolgárságáról önként történő le-mondásában és azt sem tudják igazolni, hogy Kanadában öt bármely hatóság a bevándorlásával kapcsolatban bármikor eljárás alá vonta volna. ${ }^{130}$ (XXIV.sz. melléklet)

Ezzel a dokumentummal megdőlt az vád is, hogy dr. CSATÁRY László Lajost háborús büncselekmények elkövetése miatt állampolgárságától megfosztották és Kanadából kiutasították volna.

\section{Utóhang}


A budapesti népbíróság peranyaga, a kassai népbíróság peranyaga, valamint a levéltárakból, közkönyvtárakból előkerült, továbbá más dokumentumok már több évtizede bárki számára hozzáférhetők, teljes terjedelmükben kutathatók.

A dr. CSATÁRY László ügy bővebb összefoglalása egy 2014 őszén kiadott könyvben valósult meg. ${ }^{131}$

\section{Jegyzetek:}

${ }^{1}$ A peretsényi NóRÁNTH Gerzson, nemzetes СHOBÁNKY Kálmánnak írt levelének részlete, amely kelt 1863 március havában Debrecenben.

ERDEI 22.p.

${ }^{2}$ Dr. CSATÁRY László Lajost CSATÁRI László Lajos néven anyakönyvezték 1915-ben. Nevét fordulatos életútja során többféleképpen írták. Az adott nyelvi környezetböl és a hivatalnokokon múlt az, hogy hol „i”, hol pedig „," betűvel jegyezték a családi nevét. A név elötagja a „csizsik” rész pedig az emigráció időszakában került a neve elé, melyet az anyai nagypapájától örökölt. A „csizsik” előnév a kanadai honosítását követően már nem került rá okmányaira. Jogi doktorátust a debreceni Tisza István Magyar Királyi Tudományegyetem Jog- és Államtudományi Karán 1937-ben szerzett.

${ }^{3}$ PARÁDI: A dualizmuskori magyar rendvédelem. ; Idem: A két világháború közötti Magyar Királyság rendvédelme. ; Idem: A polgári magyar rendvédelem a XIX-XX. században.

${ }^{4}$ 1872/XXXVI.tc. ; 1881/XXI.tc.

5 1903/VIII.tc.

${ }^{6} 1916 /$ XXXVII.tc.

${ }^{7} 1870 /$ XLII.tc. ; $1871 /$ XVIII.tc.

85 047/1919. (X. 1.) ME.r.

${ }^{9} 1881 /$ II.tc. $\quad ; 1881 /$ III.tc.

${ }^{10}$ PARÁDI: A katonailag szervezett örtestület és a polgári fegyveres örtestület.

${ }^{11}$ ZEIDLER

126 500/1931. (XI. 30.) ME.r.

${ }^{13} 2$ 300/1944. (VI.21.) ME.r.

${ }^{14}$ BFL. 197/1946.

${ }^{15}$ KAL. Tk 358/1948.sz.

${ }^{16}$ FCCA. T 2399-96.

${ }^{17}$ 2012. VII. 18-án a Budai Központi Kerületi Bíróság dr. CSATÁRY László Lajos házi őrizetbe helyezéséről szóló végzése.

BKKB.I. 17. Bny. 942/2012/2.sz. végzés. ; BNYÜ.I. nyom. 1597/2011. V. kötet 2803-2806.p.

${ }^{18} 2011$-ben a nyomozás elrendelésekor még a régi büntetötörvénykönyv az 1978. évi IV. törvény volt hatályban. 1978/IV.tv.

${ }^{19} \mathrm{Az}$ 1945. évi törvénnyel törvényeröre emelt és az1945. évi miniszterelnöki rendelettel módosított, valamint ugyancsak ezévi miniszterelnöki rendelettel kiegészített rendelet rendelkezett a háborús büntettekről.

1945/VII.tv. I.sz.melléklet. ； 1440/1945. (IV. 27.) ME.r. ； 81/1945. (I. 25.) ME.r.

${ }^{20}$ 1945/VII.tv. I.sz. melléklet

${ }^{21}$ BNYÜ.I. nyom. 1597/2011. op.cit. Efraim ZuROFf dr. CSATÁRY László Lajos ellen a Budapesti Nyomozó Ügyészségen tett feljelentése. I. kötet 109-113-p. és 127-213.p. 219-229.p.

${ }^{22}$ Loc.cit. 109-113.p. + 219-225.p.

${ }^{23}$ KAL. Tk 358/1948.sz. op.cit.

${ }^{24}$ CsATÁRY László Lajos elleni feljelentésről a szlovákiai sajtó is tájékoztatta olvasóit.

${ }^{25} 2015$ novemberében Kassán, a szóban forgó féri fiával történő beszélgetésem során az derült ki, hogy a kassai nyomozó hatóság felé pusztán az volt a kérése, hogy dr. CSATÁRY László Lajost a magyarországi eljárás során ebben az ügyben is hallgassák meg, mert számára évtizedek óta tudott volt, hogy 1944 októberét követően dr. CSATÁRY László Lajos már nem tartózkodott Kassán.

${ }^{26}$ BNYÜ.I. nyom. 1597/2011. op.cit. 49.sz. határozat dr. CSATÁRY László Lajos ellen ebben az ügyben a Budapesti Nyomozó Ügyészség a nyomozást megszüntető határozata.

${ }^{27}$ BALKÁNYI Sándor tanúvallomása képezte a 2011 öszén a dr. CSATÁRY László Lajos ellen tett feljelentés alapján a későbbi, 2012 júliusában a Budapesti Nyomozó Ügyészség által közölt háborús büncselekmény elkövetése miatti gyanúsítás alapját és a 2013 júniusában befejezett nyomozás vádemelési indítványát.

${ }^{28}$ BNYÜ.I. nyom. 1597/2011. op.cit. 49.sz. határozat.

${ }^{29}$ CSLL.MI. 197/1946.sz. budapesti népbíróság dr. CSATÁRY László Lajos ügyében lefolytatott tárgyalási iratai.

${ }^{30}$ KAL. Tk 358/1948.sz. op.cit.

${ }^{31}$ CSLL.MI. op.cit. T 2399-96. I-V köt. Kanadai Királyi Szövetségi Rendörség (The Royal Canadien Mounted Police) 1993 és 1997 között dr. CsATÁRY László Lajos ügyében hat országra kiterjedő nyomozási anyagának öt kötetnyi másolata.

${ }^{32}$ Loc.cit. dr. CSATÁRY László Lajos 1940. I. 5-én kelt 366 620/1939.VI-a. számú rendőr fogalmazó gyakornoki kinevezési okmánya a kecskeméti rendőrkapitánysághoz. 
${ }^{33}$ Loc.cit. dr. CSATÁRY László Lajos 1941. XII. 3-ai 226 836/1941. VI.a. számú rendőr segédfogalmazó kinevezési okmánya a kecskeméti rendőrkapitánysághoz.

${ }^{34}$ Loc.cit. dr. CSATÁRY László Lajos 1942. III. 13-án 153 570/1942. VI.a. áthelyezési parancsa Kecskemétröl Zomborra.

3539 820/1921. (1922. IV. 18.) BM.r.

${ }^{36}$ A rendörség szervezete és ügyvitele. 52-53.p.

3739 820/1921. (1922. IV. 18.) BM.r. op.cit.

${ }^{38}$ CsÖsZ: 80.p.

${ }^{39}$ MNL. 4/503. tételszám alatt nyilvántartott kötet. Magyarország Tiszti Cím- és Névtára. Pótfüzet. 1944.

${ }^{40}$ Elöszó.

${ }^{41}$ A budapesti Holokauszt Emlékközpontban 2012. VII. 25-én szervezett konferenciáról szóló sajtótájékoztató összefoglalójában dr. CSATÁRY László Lajost mint a kassai gettó parancsnokát említették meg.

GELLÉRT

${ }^{42}$ BFL. 197/1946. op.cit. dr. HoRVÁTH György ítélete. 14.p.

${ }^{43}$ BRAHAM: I.köt. 572.p.

${ }^{44}$ Loc.cit. 592.p.

${ }^{45}$ GASKÓ: $12 . p$.

${ }^{46}$ BRAHAM: op.cit. 592.p.

${ }^{47}$ BUCHLER - SASHAK: 495-505.p.

${ }^{48}$ KAL. Tk 358/1948.sz. op.cit.

${ }^{49}$ Loc.cit.

${ }^{50}$ BFL. 197/1946. op.cit. 22.p.

${ }^{51}$ Loc.cit. 94.p.

${ }^{52}$ Loc.cit. 58.p.

${ }^{53}$ Loc.cit. 88.p.

${ }^{54}$ Loc.cit. 103.p.

${ }^{55}$ BNYÜ.I. nyom. 735/47.sz. ŠTRAKOVÁ Terézia Glücksmannová (GLÜCKSMANN Teréz) vallomása

${ }^{56}$ BNYÜ.I. nyom. 1597/2011. op.cit. IV. kötet 2397.p. és Tl’ud735/47. és A kassai népbíróság Tk 358/1948. számú eljárása hiteles magyar nyelvü fordítása.

${ }^{57}$ Loc.cit. IV. kötet 2455.p.

${ }^{58}$ BFL. 197/1946. op.cit. 46-47.p.

${ }^{59}$ Loc.cit. 122.p.

${ }^{60}$ Loc.cit. 141.p.

${ }^{61}$ BNYÜ.I.nyom. 1597/2011. op.cit. IV. kötet 2303.p. + 2391.p. és Tk735/47 és a kassai népbíróság Tk 358/1948. számú eljárása hiteles magyar nyelvű fordítása.

${ }^{62}$ GELLÉRT: op.cit.

${ }^{63}$ BFL. 197/1946. op.cit. 12.p.

${ }^{64}$ Loc.cit. 11-13.p.

${ }^{65}$ Loc.cit.

${ }^{66}$ Loc.cit.

${ }^{67}$ Loc.cit. 116.p.

${ }^{68} \mathrm{~A}$ témakörben írt cikk lényegét több felvidéki sajtóorgánum is átvette.

${ }^{69}$ BNYÜ.I.nyom. 1597/2011. op.cit. II. kötet 1463-1477.p. KRPZ-KE-KPI-288/2013.sz.

${ }^{70}$ Loc.cit. A kassai népbíróság Tk 358/1948.számú eljárása hiteles magyar nyelvü fordítása. I.-VI. kötetek.

${ }^{71}$ Loc.cit. IV. kötet 2399-2455.p.

${ }^{72}$ Loc.cit. A kassai népbíróság Tk 358/1948.számú eljárása hiteles magyar nyelvủ fordítása. IV. kötet 2413.p.

${ }^{73}$ Loc.cit. A kassai népbíróság Tk 358/1948.számú eljárása hiteles magyar nyelvü fordítása. IV. kötet 2463.p.

${ }^{74}$ Loc.cit. Dr. Karol NEMENY vallomása. A kassai népbíróság Tk 358/1948.számú eljárása hiteles magyar nyelvü fordítása. IV. kötet 2461.p.

${ }^{75}$ Loc.cit. IV. kötet 2461.p.

${ }^{76}$ Loc.cit. Dr. Stefan KAIFER személyes érintettsége indokával utasította el dr. CSATÁRY védelmének ellátását. IV. kötet 2447.p.

${ }^{77}$ Loc.cit. A kassai népbíróság Tk 358/1948.számú eljárása hiteles magyar nyelvü fordítása. IV. kötet 2463.p.

${ }^{78}$ Loc.cit. Dr. Stefan KAIFER erre az eseményre hivatkozva hárította el dr. CSATÁRY László Lajos védelmét a kassai népbíróság felé 1948-ban.IV. kötet 2343. + 2447.p.

${ }^{79}$ Loc.cit. VI. kötet 3659-3677.p.

${ }^{80}$ Loc.cit. szaktanácsadó kirendelése + a szaktanácsadói válasz BNYÜ-i értékelése.

${ }^{81}$ BFL. 197/1946. op.cit. 80.p.

${ }^{82}$ A Kassai Rendőrkapitányság 1/1945.biz.sz. nyomozati jelentés. MNL. K szekció, op.cit. 345/1945. 103.p.

${ }^{83}$ Gyarmathy Gábor kassai főispán, hadmüveleti kormánybiztos 9/H. 1945. számon hozott ítélete. MNL. K szekció, op.cit. 345/1945. 102.p.

${ }^{84}$ KAL. Tk 358/1948.sz. op.cit.

${ }^{85}$ Efraim ZuROFF a dr. CSATÁRY László Lajos elleni feljelentésében a születési napot március 3-nak adta meg.

${ }^{86} \mathrm{~A}$ jelzett címen abban az időben és jelenleg is, a kassai rendőrkapitányság épülete található.

${ }^{87}$ BNYÜ.I.nyom. 1597/2011. op.cit. A kassai népbíróság Tk 358/1948. számú eljárása hiteles magyar nyelvü fordítása. XII.köt.5.sz. és IV. kötet 2431.p.

${ }^{88}$ MNL.I. op.cit., 1947/1946. a NOT az 1947/1948. sz. eljárásban JAROSS Andor, ENDRE László és BAKY László háborús főbűnösöket halálra ítélte.

${ }^{89}$ Loc.cit., I.3923/1946. a NOT a 3923/1946. sz. eljárásban FERENCZY László háborús főbűnöst halálra ítélte. 
${ }^{90}$ BRAHAM: op.cit. 96.p.

${ }^{91}$ A Népföügyészség által 1946 augusztusában összeállított háborús bűnösöket tartalmazó lista.

MNL. op.cit. XX-1-a-XVIII:A-1.

${ }^{92}$ BFL. 197/1946. op.cit. 197.p.

93 KovÁCs: 294 p.

942 300/1944. (VI.21.) ME.r. op.cit.

${ }^{95}$ HIM.HL. M.Kir. Rendőrség iratai, növekedési naplószám 52/2010. 1 p.

${ }^{96}$ SZAKÁLY: 132-133.p.

${ }^{97}$ BNYÜ.I. nyom. 1597/2011. op.cit. III. kötet 2257.p.

${ }^{98}$ CSLL.MI. op.cit. Kanadai Királyi Szövetségi Rendőrség (The Royal Canadien Mounted Police) 1993 és 1997 között dr. CSATÁRY László Lajos ügyében hat országra kiterjedő nyomozási anyagának öt kötetnyi másolata. T 239996. V köt.

${ }^{99}$ Loc.cit. 1945-1946-ban dr. HoRvÁTH György volt kassai rendör-főkapitány helyettes háborús bünös ügyében lefolytatott budapesti népbírósági eljárás és 1947-1948-ban dr. CSATÁRY László Lajos volt „magyar kassai rendőrfőkapitány" ellen a kassai népbíróság által TK 358/1948 számon lefolytatott népbírósági eljárás iratanyagai. 197/1946.sz. + TK 358/1948.sz.

${ }^{100}$ Loc.cit. Susan Kiss tanúkihallgatási jegyzőkönyve. T 2399-96.sz.dosszié.

${ }^{101}$ Loc.cit. Judy LYSY tanúkihallgatási jegyzökönyve.

${ }^{102}$ Loc.cit. Dr. Stefan KAIFER tanúkihallgatási jegyzőkönyve.

${ }^{103}$ Loc.cit. Steve SAS tanúkihallgatási jegyzőkönyve.

${ }^{104}$ Loc.cit. Georg Z. WASSERMAN tanúkihallgatási jegyzökönyve.

${ }^{105}$ Loc.cit. Shachar YESHA’AYAHU tanúkihallgatási jegyzőkönyve.

${ }^{106}$ Loc.cit. A Kanadai Királyi Szövetségi Rendőrség (Royal Canadien Mounted Police) és a magyar Legföbb Ügyészség ál-tal Budapesten 1994. XI. 15-én dr. MÉszÁRos Győzőtől felvett tanúvallomás jegyzőkönyve. T 2399-96. IV.köt.

${ }^{107}$ Loc.cit. Susan Kiss tanúkihallgatási jegyzőkönyve. T 2399-96.sz.dosszié.

108 - Loc.cit. budapesti népbíróság 197/1948.sz. iratai. 197/1946.sz. fordítása.

- BNYÜ.I. nyom. 1597/2011. op.cit. A kassai népbíróság Tk 358/1948.számú eljárása hiteles magyar nyelvü

- A Kanadai Királyi Szövetségi Rendőrség (Royal Canadian Mounted Police) 1993 és 1997 között végzett nyomozási iratai.

CSLL.MI. op.cit. T 2399-96. IV.köt.

109 BNYÜ.I. nyom. 1597/2011. op.cit. A kassai népbíróság Tk 358/1948.számú eljárása hiteles magyar nyelvü fordítása.

${ }^{110}$ FCCA. T 2399-96. op.cit.

${ }^{111}$ CSLL.MI. op.cit. FüZESY István rendőr százados, a Simbach am Inn-i Magyar Iroda vezetője 1949. V. 6-án kelt igazolása arról, hogy dr. CSATÁRY László háború alatti magatartását az illetékes USA hatóságok lenyomozták és megállapították, hogy demokratikus módon végezte munkáját, és a háború alatt tanúsított viselkedését elfogadhatónak találták.

${ }^{112}$ BFL. 197/1946. op.cit.

${ }^{113}$ KAL. Tk 358/48. op.cit.

${ }^{114}$ CSLL.MI. op.cit. 197/1946.sz.

${ }^{115}$ BFL. 197/1946. op.cit. 4.p.

${ }^{116}$ Loc.cit.

${ }^{117}$ Loc.cit. 131.p.

${ }^{118}$ KAL. Tk 358/48. op.cit. ; BFL. 197/1946. op.cit.

119 KAL. op.cit. Tk 358/48.op.cit és 5.sz. Dr. CSATÁRY László Lajos ellen a kassai népbíróság által kiadott elfogató parancs.

${ }^{120}$ CSLL.MI. op.cit. A dr. CSATÁRY László Lajos számára 1943-ban Kassán kiállított 499073. számú útlevél 1. és 2. oldala.

${ }^{121}$ Loc.cit. A dr. CSATÁRY László Lajos számára 1943-ban Kassán kiállított útlevélben rögzített személyleírás. 3. és 4. oldala.

${ }^{122}$ Loc.cit. A dr. CsATÁRY László Lajos számára 1948-ban Münchenben kiállított B.XXVI/23453 számú személyi igazolványban szereplő személyleírás.

${ }^{123}$ A rendőrség szervezete és ügyvitele. op.cit. 76-77.p. Budapest, 1943, 200 p. Magyar Királyi Belügyminisztérium.

${ }^{124}$ CSLL.MI.op.cit. Dr. CSATÁRY László Lajosról készült fényképek.

125 A korabeli Szlovákiában a kassai népbíróság dr. CSATÁRY László Lajos elleni „kollaboráció és fasiszta megszállás" vádját olyan esetben hozta fel, amikor a felvidéki Kassa az első bécsi döntés értelmében 1938-tól a Magyar Királysághoz tartozott, illetve 1944. III. 19-től pedig német megszállás alá került.

${ }^{126}$ BFL. 197/1946. op.cit. 20-23.p.

${ }^{127}$ BFL. 197/1946. op.cit. 21.p.

128 - Dr. CSATÁRY László Lajos védője az iratok beszerzésre a 2012. VIII.17-ei gyanúsított kihallgatás során indítványt tett.

BNYÜ.I. nyom. 1597/2011. op.cit. gyan. jkv. 26.p.,

- Az iratismertetési jkv. szerint a jogsegély megkeresésre a kanadai hatóságok nem reagáltak.

BNYÜ.I. nyom. 1597/2011. op.cit. VI. kötet 4381.p.

${ }^{129}$ BFL. 197/1946. op.cit. ; KAL. Tk 358/1948.op.cit.

${ }^{130}$ CSLL.MI.op.cit. A Kanadai Igazságügyi Minisztérium 2015. IV. 13-án kelt levele.

${ }^{131}$ VerbovsZKI 
Jegyzetekben alkalmazott röviditések:

\section{MONOGRÁFIÁK, KISMONOGRÁFIÁK ÉS HASONLÓ JELLEGÜ KÖTETEK}

BRAHAM

(43.;44.;46.;90.;)

BUCHLER - SASHAK

(47.;)

SZAKÁLY

(96.;)

VERBOVSZKI

(131.;)

\section{TANULMÁNYOK}

ERDEI

$(1 . ;)$

PARÁDI József: A dualizmuskori magyar rendvédelem.

(3.;)

PARÁDI: A két világháború közötti Magyar Királyság rendvédelme.

(3.;)

PARÁDI: A polgári magyar rendvédelem a XIX-XX. században.

(3.;)

PARÁDI: A katonailag szervezett őrtestület és a polgári fegyveres örtestület. (10.;)

ZEIDLER

(11.;)

\section{CIKKEK}

GASKÓ

(45.;)

\section{KÉZIRATOK}

CsősZ

(38.;)

Kovács

(93.;)
Randolph L. BraHAm: A népirtás politikája. A holokauszt Magyarországon. I-II. [The politics of genocide. The Holocaust in Hungary. I-II.] Ford.: BERÉNYI Gábor - GARAI Attila - HERNÁDI Miklós Sz. Kiss Csaba - SEREs Iván - ZALA Tamás. Budapest, 1997, Belvárosi Könyvkiadó. 1474 p. HU-ISBN 963767585 X.

- Yehoshua Robert Buchler - Ruth SASHAK (szerk.): ,,Kosice” Encyclopaedia of jewish communities, Slovakia. [„Kassa”. A szlovákiai zsidó közösségek enciklopédiája.] 495-505.p. Jeruzsálem, 2003, Yad Vashem, 596 p. , ISBN 9653081780.

- SzAKÁly Sándor: A magyar katonai felsövezetés 1938-1945. Budapest, $2003^{2}$ (javított kiadás), Ister. 409 p. HU-ISBN 9639243760.

- VerbovszKi Sándor: „Kassa árnyékában. A Csatáry-ügy a dokumentumok tükrében" Budapest, 2014, VerBOVSZKI Sándor. 220 p. HU-ISBN 9786151553741.

- ERdei Árpád: Mi az igazság? In ERdEI Árpád et al. (szerk.): A büntetô itélet igazságtartalma. Budapest, 2010, Magyar Lap- és Könyvkiadó. 174 p. HU-ISBN 9789639722897.

PARÁDI József: A dualizmuskori magyar rendvédelem. Rendvédelem-történeti Füzetek (Acta Historiae Praesidii Ordinis), XVIII.évf. (2010) 21.sz. 66-84.p. HU-ISSN 1216-6774. A tanulmány korábbi változata 2007. október 05-én Budapesten hangzott el a Szemere Bertalan Magyar Rendvédelem-történeti Tudományos Társaság által szervezett rendvédelem-történeti tudományos konferenciasorozatnak „A rendvédelem fejlödése a XIX-XX. században” címü XXI. konferenciáján. A publikált tanulmány az előadás javított, bővített és átdolgozott változata.

PARÁDI József: A két világháború közötti Magyar Királyság rendvédelme. Rendvédelem-történeti Füzetek (Acta Historiae Praesidii Ordinis), HU-ISSN 1216-6774. XVIII. évf. (2010) 21.sz. 85-100.p. A tanulmány korábbi változata 2007. október 05-én Budapesten hangzott el a Szemere Bertalan Magyar Rendvédelem-történeti Tudományos Társaság által szervezett rendvédelem-történeti tudományos konferenciasorozatnak „A rendvédelem fejlődése a XIX-XX. században” címü XXI. konferenciáján. A publikált tanulmány az előadás javított, bővített és átdolgozott változata.

PARÁDI József: A polgári magyar rendvédelem a XIX-XX. században. Rendvédelem-történeti Füzetek (Acta Historiae Praesidii Ordi$n i s)$, HU-ISSN 1216-6774. XIX. évf. (2010) 22.sz. 60-76.p. A tanulmány korábbi változata 2008. október 10-én Budapesten hangzott el a Szemere Bertalan Magyar Rendvédelem-történeti Tudományos Társaság által szervezett rendvédelem-történeti tudományos konferenciasorozatnak „,Másfél évszázad rendszerváltozásainak hatásai nemzeti rendvédelmünkre" címü XXII. konferenciáján. A publikált tanulmány az elöadás javított, bővített és átdolgozott változata.

PARÁDI József: A katonailag szervezett őrtestület és a polgári fegyveres örtestület. Rendvédelem-történeti Füzetek (Acta Historiae Praesidii Ordinis), XXV.évf. (2015) 43-44-45-46.sz. 77-87.p. HU-ISSN 1216-6774.

- ZEIDLER Sándor: A magyar rendőri rangok fejlődéstörténete a kiegyezéstöl az ezredfordulóig. Rendvédelem-történeti Füzetek (Acta Historiae Praesidii Ordinis), XIV.évf. (2008) 17.sz. 116-137.p. HUISSN 1216-6774.

- GASKó Miklós: A halálvonatok. Menóra-egyenlöség, XXIX.évf. (1984) június 1. 4-12.p. CA-ISSN 0837-2861.

Csősz László: Tettesek, szemtanúk, áldozatok A vészkorszak JászNagykun-Szolnok Megyében. Ph.D. disszertáció (SZTE-BTK Történelemtudományi Doktori Iskola). Kézirat. Szeged, 2010. 180 p.

KovÁcs Zoltán András: A Szálasi-kormány belügyminisztériuma. Rendvédelem, állambiztonság a nyilas korszakban. Ph.D. disszertáció (PTE-BTK). Kézirat. Pécs, 2008. 306 p. 


\section{SEMATIZMUSOK}

Előszó.

(40.;)

\section{SZABÁLYZATOK}

A rendörség szervezete és ügyvitele. (36.;123.;)

\section{LEVÉL-, IRAT- ÉS DOKUMENTUMTÁRAK}

ÁBTL. (41.;)

BFL. 197/1946.

(14.;42.,50.;51.;52.;53.;54.;58.;59.;60.; 63.,64.,65.;66.;67.;81.,92.;112.;115.; 116.;117.;118.;126.;127.;129.;)

BKKB.I.

(17.;)

BNYÜ.I. nyom. 735/47.sz. (55.;)

BNYÜ.I. nyom. 1597/2011. (17.;21.;22.,;26.;28.;56.;57.;61.;69.;70.; 71.,72.;73.;74.,75.,76.;77.;78.;79.;80.; 87.;97.;108.;109.;128.;)

CSLL. MI.

(29.;31.;32.;33.;34.;98.;99.;100.;101.; 102.;103.;104.;105.;106.;107.;108.; 111.;114.;120.;121.;122.;124.;130.;)

FCCA. T 2399-96.

(16.;110.;)

HIM.HL.

(95.;)

KAL. Tk 358/1948.sz.

(15.;23.;30.;48.;49.;84.;113.;118.;119.; 129.;)

MNL

(39.;82.;83.;88.;89.;91.,)

\section{JOGSZABÁLYOK}

\section{0/XLII.tc.}

(7.;)

1871/XVIII.tc.

(7.;)

1872/XXXVI.tc.

(4.;)

1881/II.tc.

(9.;)

1881/III.tc.

(9.;)

1881/XXI.tc.

(4.;)

1903/VIII.tc.

(5.;)

1916/XXXVII.tc.

(6;)

1945/VII.tv.

(19.;20.;)

1978/IV.tv.

(18.;)

5 047/1919. (X. 1.) ME.r.

(8.;)

39 820/1921. (1922. IV. 18.) BM.r. (35.;37.,)
Előszó. 1.p. In: Magyarország Tiszti Cím- és Névtára. LI.évf. Budapest, 1944, Magyar Királyi Központi Statisztikai Hivatal. 1062 p.

- Állambiztonsági Szolgálatok Történeti Levéltára.

Budapest Fővárosi Levéltár. budapesti népbíróság a dr. HоRVÁTH György volt kassai rendőr-fökapitány helyettes ügyében lefolytatott tárgyaláson felmerült dr. CSATÁRY László Lajost érintő iratai.

— Budapesti Központi Kerületi Bíróság Irattára.

BNYÜ.I. nyom. 735/47.sz. Az 1948-as CSATÁRY László Lajos ellen lefolytatott kassai népbírósági eljárás során készült rendőrségi jegyzőkönyv.

— BNYÜ.I. nyom. 1597/2011. A Budapesti Nyomozó Ügyészség által dr. CSATÁRY László Lajos ellen lefolytatott nyomozás iratai.

Dr. CSATÁRY László Lajos magánirattára.

The Federal Court of Canada Archives (Kanadai Szövetségi Bíróság Irattára.) T 2399-96. Dr. CSATÁRY László Lajos lakcímbejelentését igazoló iratról készült hiteles másolat.

— Hadtörténeti Intézet és Múzeum Hadtörténelmi Levéltár.

- Kassai Állami Levéltár Tk 358/1948.sz. A dr. CSATÁRY László Lajos ellen lefolytatott Kassai népbírósági tárgyalás jegyzőkönyve.

Magyar Nemzeti Levéltár.

— 1870/XLII.tc. a köztörvényhatóságok rendezéséröl.

1871/XVIII.tc. a községek rendezéséről.

1872/XXXVI.tc. Buda-Pest fővárosi törvényhatóság alakításáról és rendezéséröl.

1881/II.tc. a csendőrség legénységi állományának kiegészítéséről.

1881/III.tc. a közbiztonsági szolgálat szervezéséről.

1881/XXI.tc. a Budapest-fővárosi rendőrségröl.

1903/VIII.tc. a határrendőrségröl.

1916/XXXVII.tc. a Fiumei Magyar Királyi Állami Rendőrségről.

1945/VII.tv. a népbíráskodások tárgyában kibocsátott kormányrendeletek törvényeröre emeléséről.

1978/IV.tv. a Büntető Törvénykönyvröl.

5 047/1919. (X. 1.) ME.r. a rendőrség államosításáról. Magyarországi Rendeletek Tára, LIII.évf. (1919) I.füzet. 752-767.p.

39 820/1921. (1922. IV. 16.) BM.r. a magyar királyi állami rendőrség szervezetének és szolgálatának szabályozása tárgyában. Budapesti Közlöny, LVI.évf. (1922) 89.sz. 1-9.p. 
6 500/1931. (XI. 30.) ME.r.

(12.;)

2 300/1944. (VI.21.) ME.r.

(13.;94.;)

81/1945. (I. 25.) ME.r.

1440/1945. (IV. 27.) ME.r.

\section{VILÁGHÁLÓS HIVATKOZÁSOK}

GELLÉRT

$(41 . ; 62 . ;)$
6 500/1931. (XI. 30.) ME.r. a rendőrség szervezeti változásairól. Magyarországi Rendeletek Tára, LXV.évf. (1931) XII.füzet. 1533-1534.p.

2 300/1944. (VI.21.) ME.r. a Magyar Királyi Rendőrség átszervezéséröl.

Magyarországi Rendeletek Tára, LXXVIII.évf. (1944) 1.sz. 10631065.p.

- 81/1945. (I. 25.) ME.r. a népbíráskodásról.

Magyarországi Rendeletek Tára, LXXIX.évf. (1945) I.füzet. 17-24.p.

- 1440/1945. (IV. 27.) ME.r. a népbíráskodásról szóló 81/1945. M.E.sz. rendelet módosítása és kiegészítése tárgyában.

Magyarországi Rendeletek Tára, LXXIX.évf. (1945) I.füzet. 121124.p.

- GelLéRT Ádám: Csatári László és az 1944-es kassai deportálások. Betekintő, VIII.évf. (2014) 3.sz. A folyóirat csak a világhálón jelenik meg oldalszámozás nélkül. HU-ISSN 1788-7569.

Világhálón:

http://www.betekinto.hu/sites/default/files/2014_3_gellert.pdf

Mellékletek jegyzéke:

I.sz. melléklet

A Magyar Királyi Állami Rendőrség, majd a Magyar Királyi Rendőrség tiszti rendfokozatai 1922-1944.

II.sz. melléklet

Dr. CSATÁRY László Lajos rendőr fogalmazógyakornoki kinevezési okmánya 1940. I. 5

III.sz. melléklet

Dr. CSATÁRY László Lajos rendőr segédfogalmazói kinevezési okmánya 1941. XII. 3.

IV.sz. melléklet

Dr. CSATÁRY László Lajos áthelyezési parancsa Kecskemétről Zomborra 1942. III. 13.

V.sz. melléklet

HIRDETMÉNY a Kassa városi gettó létrehozásáról.

VI.sz. melléklet

Dr. CSATÁRY László Lajos kézírásának tulajdonított gettóparancsnoki aláírások.

VII.sz. melléklet

A Rendőrfelügyelőség beosztottjainak névsora.

VIII.sz. melléklet

Kanadai Szövetségi Bíróság (The Federal Court of Canada) T 2399-96. számú „Ladislaus Csizsik-CSATARY” dosszié. IX.sz. melléklet

Fotó tabló a T 2399-96. számú felismertetési eljárásban.

X. sz. melléklet

Susan Kıss tanúkihallgatási jegyzőkönyvének részlete.

XI.sz. melléklet

Judy LYSY tanúkihallgatási jegyzökönyvének részlete.

XII.sz. melléklet

Dr. Stefan KAIFER tanúkihallgatási jegyzőkönyvének részlete.

XIII.sz. melléklet

SAS Steve tanúkihallgatási jegyzőkönyvének részlete.

XIV.sz. melléklet

Georg Z. WASSERMANN tanúkihallgatási jegyzőkönyvének részlete.

XV.sz. melléklet

Shachar YESHA’AYAHU fényképről történő felismertetési jegyzőkönyve.

XVI.sz. melléklet

Igazolás a CSATÁRY-család lakcím bejelentkezésről a németországi Simbach am Inn városába.

XVII.sz. melléklet

Igazolás a németországi Simbach am Inn városi Magyar iroda vezetőjétől.

XVIII.sz. melléklet

A kassai népbíróság dr. CSATÁRY László ellen kiadott elfogató parancsa.

XIX.sz. melléklet

Dr. CSATÁRY László Lajos számára Kassán 1943-ban kiállított útlevél 1. és 2. oldala.

XX.sz. melléklet

Dr. CSATÁRY László Lajos Kassán 1943-ban kiállított útlevele (3-4. oldal)

XXI.sz. melléklet

Dr. CSATÁRY László Lajos 1948-ban Münchenben kiállított német személyi igazolványa. XXII.sz. melléklet

A Magyar Királyi Rendőrség fogalmazói karba történő alkalmazás kellékei.

XXIII.sz. melléklet

Dr. CSATÁRY László Lajos rendőr segédfogalmazóról készült korabeli fényképek.

XXIV.sz. melléklet

A Kanadai Igazságügyi Minisztérium 2015. IV.13-án kelt levele. 
A Magyar Királyi Állami Rendôrség, majd a Magyar Királyi Rendőrség tiszti rendfokozatai

I.sz. melléklet 1922-1944.

FÖKAPITANYI KAR

\section{FELÜGYELOI KAR}

1922.1944
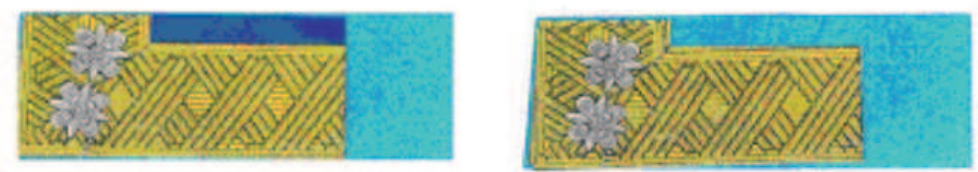

IV.FIZETÉSI

OSZTÁLY

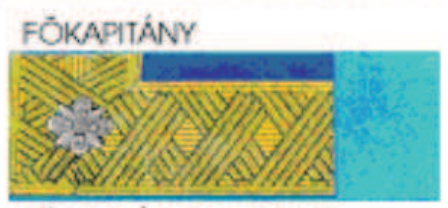

FOKAPITANYHELYEITES

FOGALMAZOI KAR

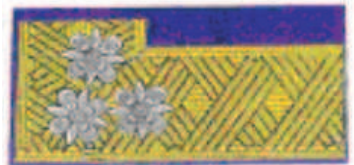

VI.R.FÓTANÁCSOS

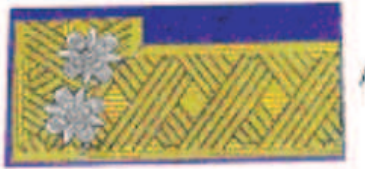

Al.R.TANÁCSOS

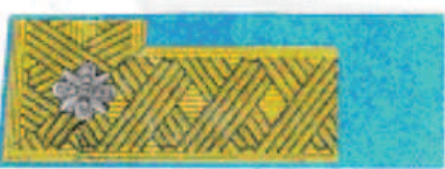

FELUGVELÓI KAR

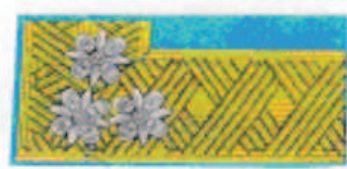

V.R.FOFELUGYELO

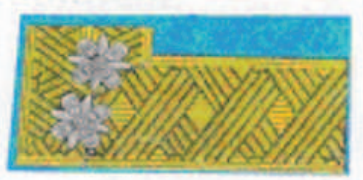

VI.RFOFFELÜGYELŌ

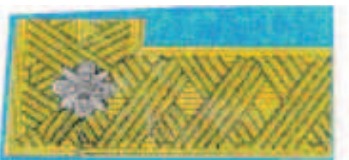

VII.R.FOFELUGYELC

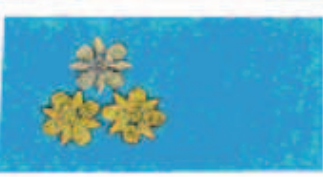

IX.R.FELUGYELO

IX.R.FOGALMAZO
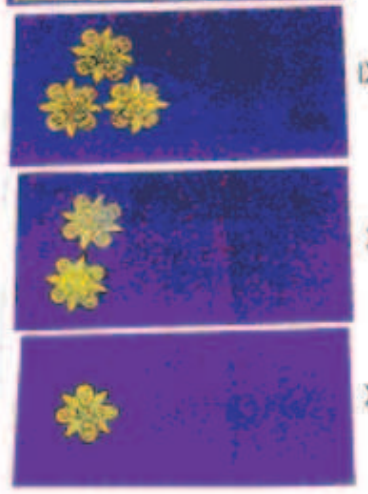

X.R.SEGEDFOGALMAZO

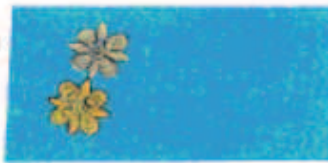

X.R.FELUGYELO

XI R.FOGALMAZO GYAKORNOK.

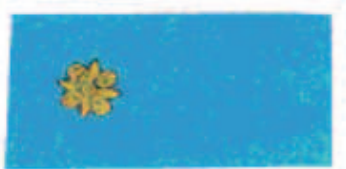

XI.R.FELUGYELO GKAKORNOK

TISZII TANFOLYAM

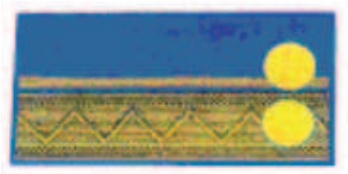
KIVÁLO
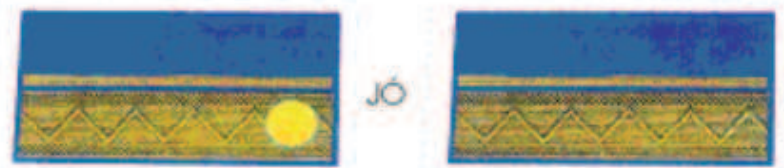

HALLGA

Megjegyzés: A katonai rendfokozatokkal ellentétben — ahol a rangokat hatágú csillaggal jelölték — a polgári fegyveres örtestületek rangjait csillagrózsácskával tüntették fel. Valamennyi polgári fegyveres örtestületnek külön rangrendszere volt. Abban azonban megegyeztek egymással és a katonai rangrendszerrel, hogy a rangrendszeren belüli csoportok három rangot tartalmaztak. Valamennyi rangot pedig a zubbony gallérján viselték.

\section{Forrás !}

- ZeIDLER Sándor: A magyar rendőri rangok fejlődéstörténete a kiegyezéstől az ezredfordulóig. 123.p. Rendvédelem-történeti Füzetek (Acta Historiae Praesidii Ordinis), XIV.évf. (2008) 17.sz. 116-137.p. 
Dr. CSATÁRY László Lajos rendör fogalmazógyakornoki kinevezési okmánya 1940. I. 5.

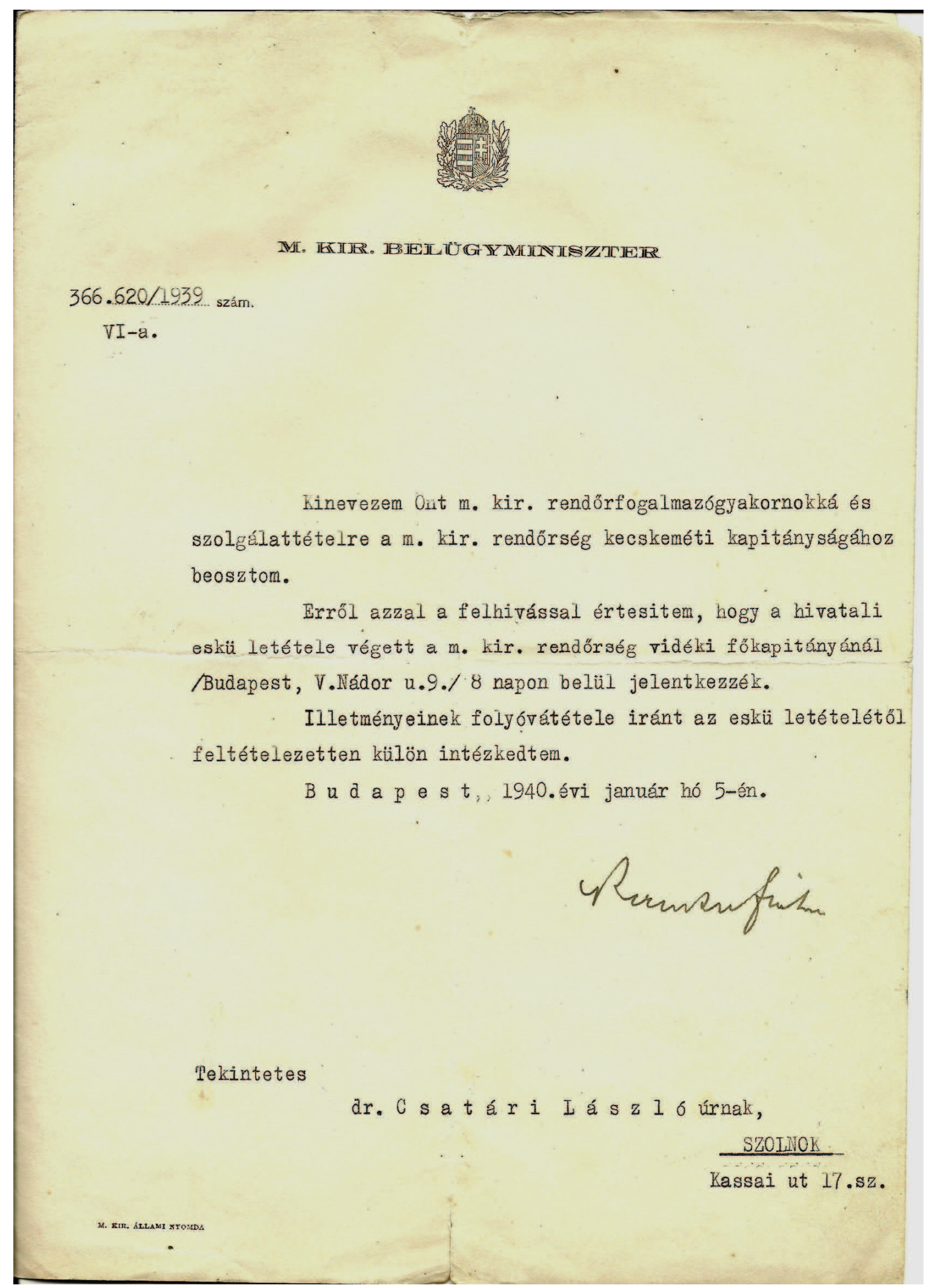

Forrás ! CSLL.MI. 
Dr. CSATÁRY László Lajos rendör segédfogalmazói kinevezési okmánya

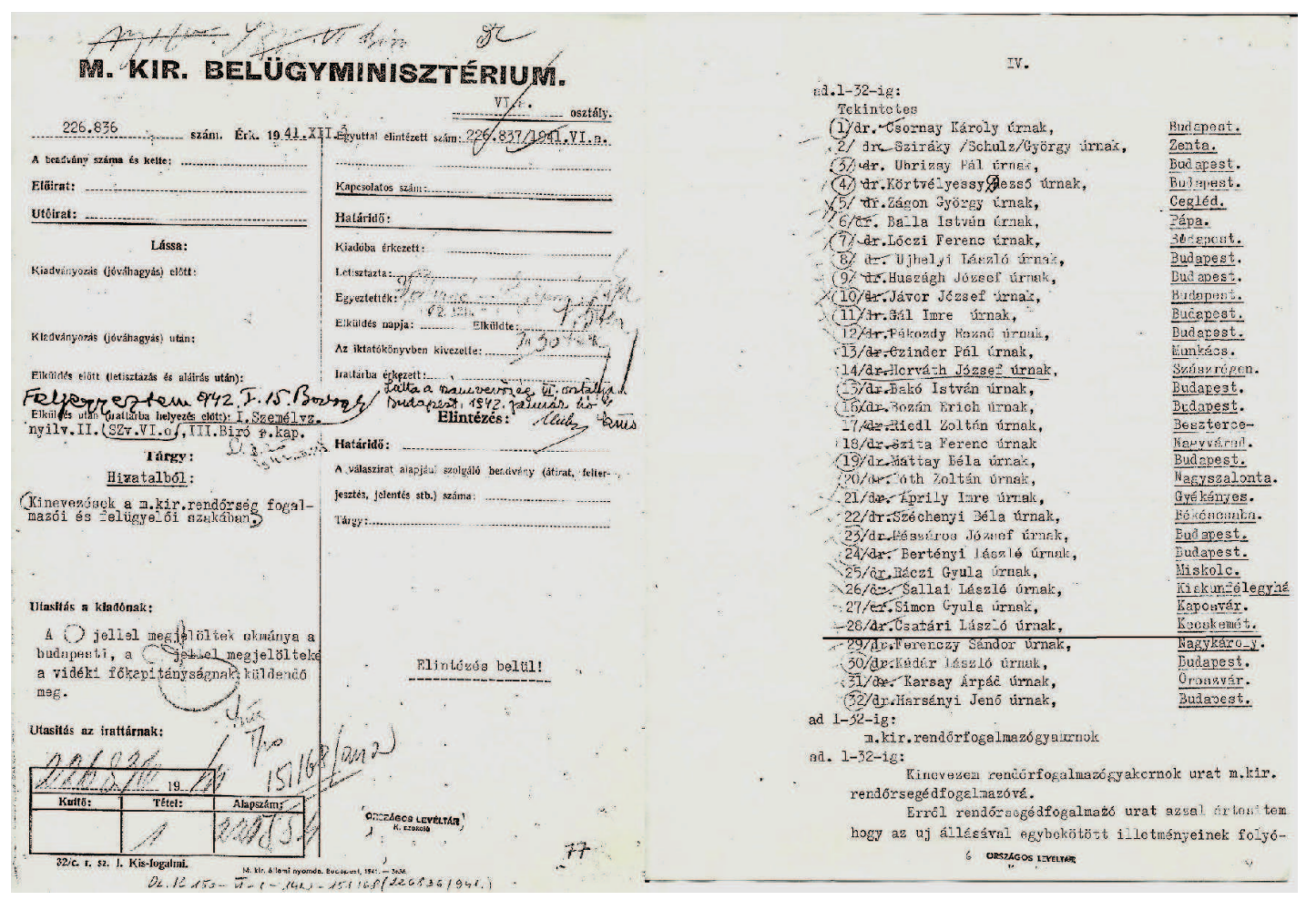

Forrás ! CSLL.MI.

Dr. CSATÁRY László Lajos áthelyezési parancsa Kecskemétröl Zomborra.

IV.sz. melléklet 1942. III. 13.

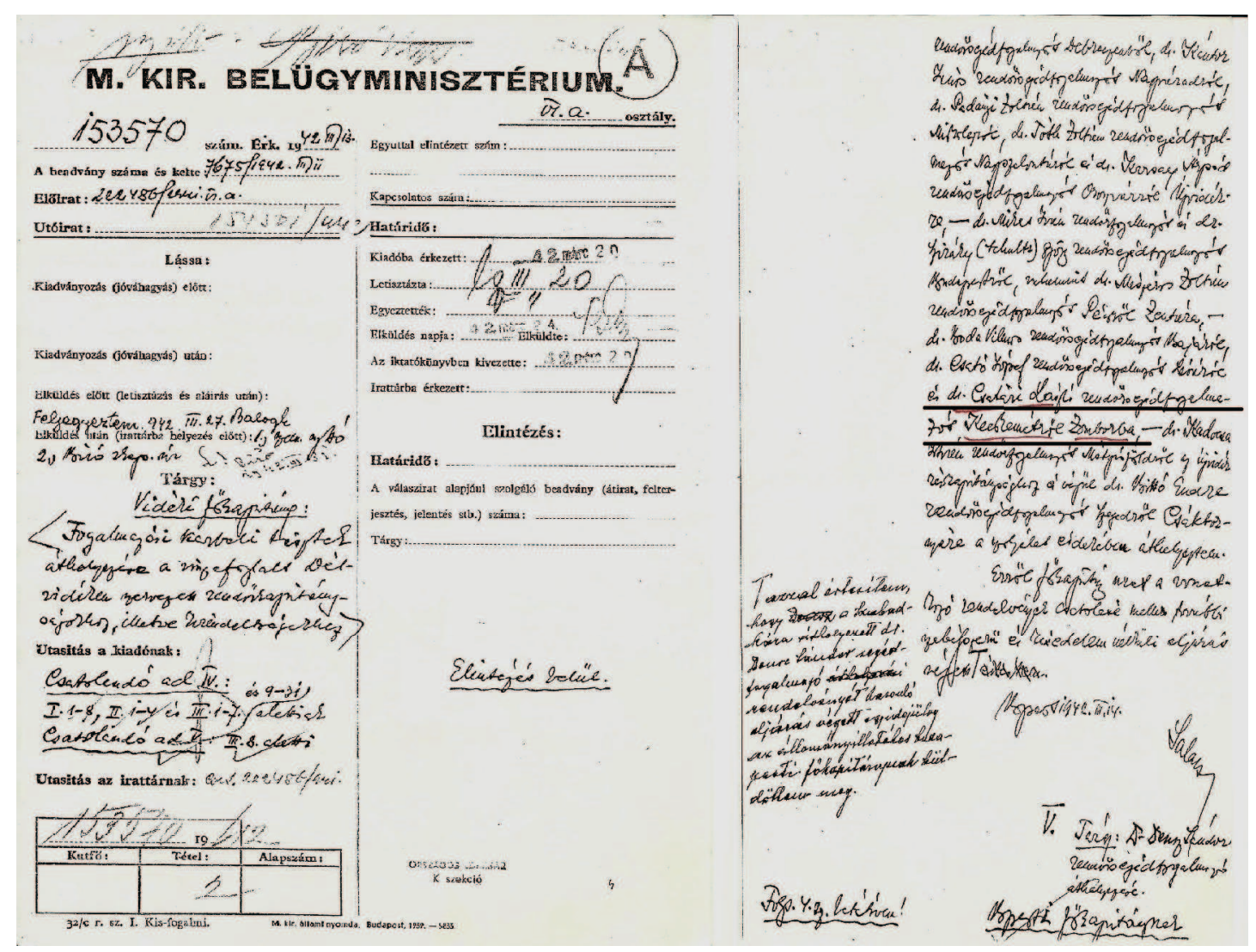

Forrás ! CSLL.MI. 


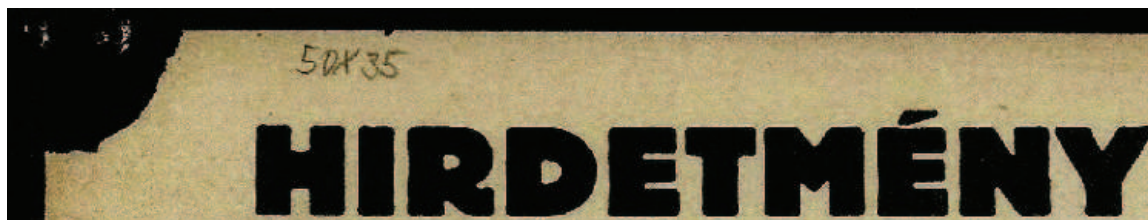

Kassu város terïletèn a zsidófajú egyének elkitiönitésére a Gettó az aläbbiakban állapittatott meg:

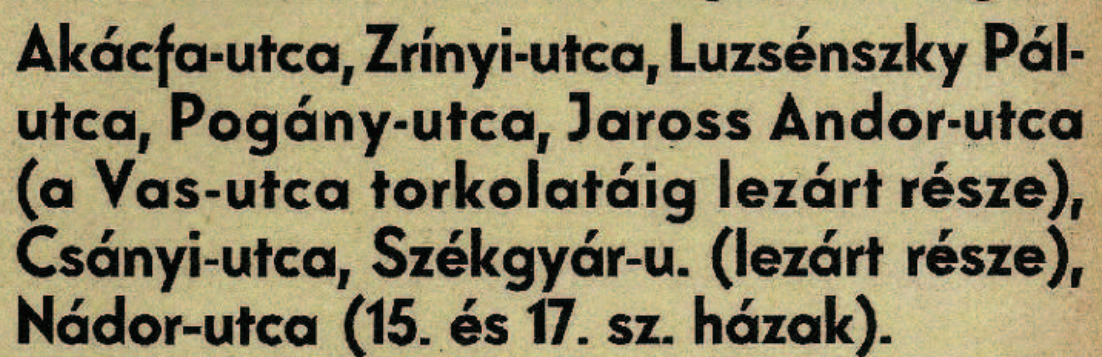

-Felhívom a Gettó területén lakó keresztény fajú lakosságot, hogy a Gettó területéröl való kiköltözésük érdekében Kassa város polgármesteri hivatalánál az intézkedéseket haladéktalanul tegyék meg, mert a mai naptól kezdődően a Gettó-parancsnokság személyi és vagyonbizłonságukért a felelösséget nem vállalja!

Elirendelem, hogy a Gettó tertiletén lakó kerestény fajú egyének an oli Iakó zsidló fujú égyénekkel mẹ érinthezhetnek, velith semminemü összelkötte: tésben nem allhatnak. A Gettó terilletén lévö tizletek, iparosok, tizemek zsidók részére kiszolgálást nem teljesithetnek; lakúsukba, udvarukba zsidót be nem fogadhatuak, zsidó fujłù egyének részére még kölesönképen sem adhatnak át senminemá élelmiszert vagy mús tárgyakat.

Zsidó fajú egyének a Gettó ułcáin nem tartózkodhainak, lakásuknak csupán udvarra nyíló ablakait tarthatják nyiłva. Minden zsidó fajú egyén köteles állandóan lakásán tartózkodni!

A Gettó-parancsnokság székhelye a Nádor-utca 15. szám alatti hóz Kereszłény fajú egyének kérelmeikkel közvełlenŭl, zsidó fajú személyek pedig a zsidó-tanács útján fordulhâtnak a parancsnoksóghoz.

A Gettó teríletének elhagyása csak hatósági engedéllyel, az erre a célra kijelölt kijárati kapukon történhet. A Gettón kívïl lakó egyéneknek a Gettó terïletére való belépését megtiltom! Szigorúan megtiltom a Gettó területére zsidó fajú egyének részére csomagok, levelek, pénz, vagy egyéb értékek be- és kiszállítását. - Jármívelnnek a Gettó területére való behajtását megtiltoml

Amennyiben a keresztény fajú lakosok közül a fenti rendelkezéseket bárki megszegi, ha cselekménye súlyosabb elbírálás alá nem kerül, az internálási eljárást megindítom; ha a fenti rendelkezéseket zsidó fajủ egyén szegi meg, úgy az illetővel szemben szigorú kényszerintézkedést fogok alkalmazni.

Kassa, 1944 május hó 1-én.

Gettó-parancsnok.

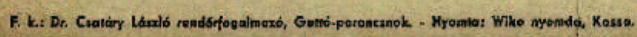

Megjegyzés: A Kassa városi gettó létrehozásáról szóló HIRDETMÉNY 1944. V. 1-én lett kiadva. A Gettó-parancsnok dr. HoRVÁTH György Kassa város vidéki rendőr-főkapitány helyettes volt. A hirdetmény lábrészében felelős kiadókként vannak feltüntetve dr. CSATÁRY László „rendőr fogalmazó”, és a Gettó-parancsnok. Kassai helytörténészek tájékoztatása szerint a városi gettó, a téglagyári gyüjtőtáborba történő beolvasztásáról a német parancsnokság döntött, és amely rövid időn belül végrehajtásra került.

Forrás ! OSzK. Nyomtatványtár. 
Dr. CSATÁRY László Lajos kézirásának tulajdonított gettóparancsnoki aláírások.

Gettó-Porancanokskg, Kassa.

M.Kir.Rendókapi tényskg,

$\mathrm{K} 2 \mathrm{~s} \mathbf{3} 2$.

Tisztelettel jelentem, hogy f.ho $4-6$ n 18.30 perckor

2. Getto-parancsnokság helyiségében megjelent dr.Laufer Lajosné, aki engedelyt kért aera, hogy zsidó faju férje a Gettó teriletón olnelyezett rabbihoz meheasen, hogy az izraelita felekezetból való kilépését bejelenthesse. Nevezett kérelmét nem teljesitettem, hanom Gazda Albert m.kir.szolgarendర్rt arra utasitottam, hogy dr. Laufer Lajost laktakn keresse fel és a Kapiténysíg központi ugyeletére fllitsa elో. Közvetlen tudomísom szerint nevezett dr.Laufer Lujos az Gjszakét lakán tólobtte.

Kasaz, 1944 . ak jus 5 .

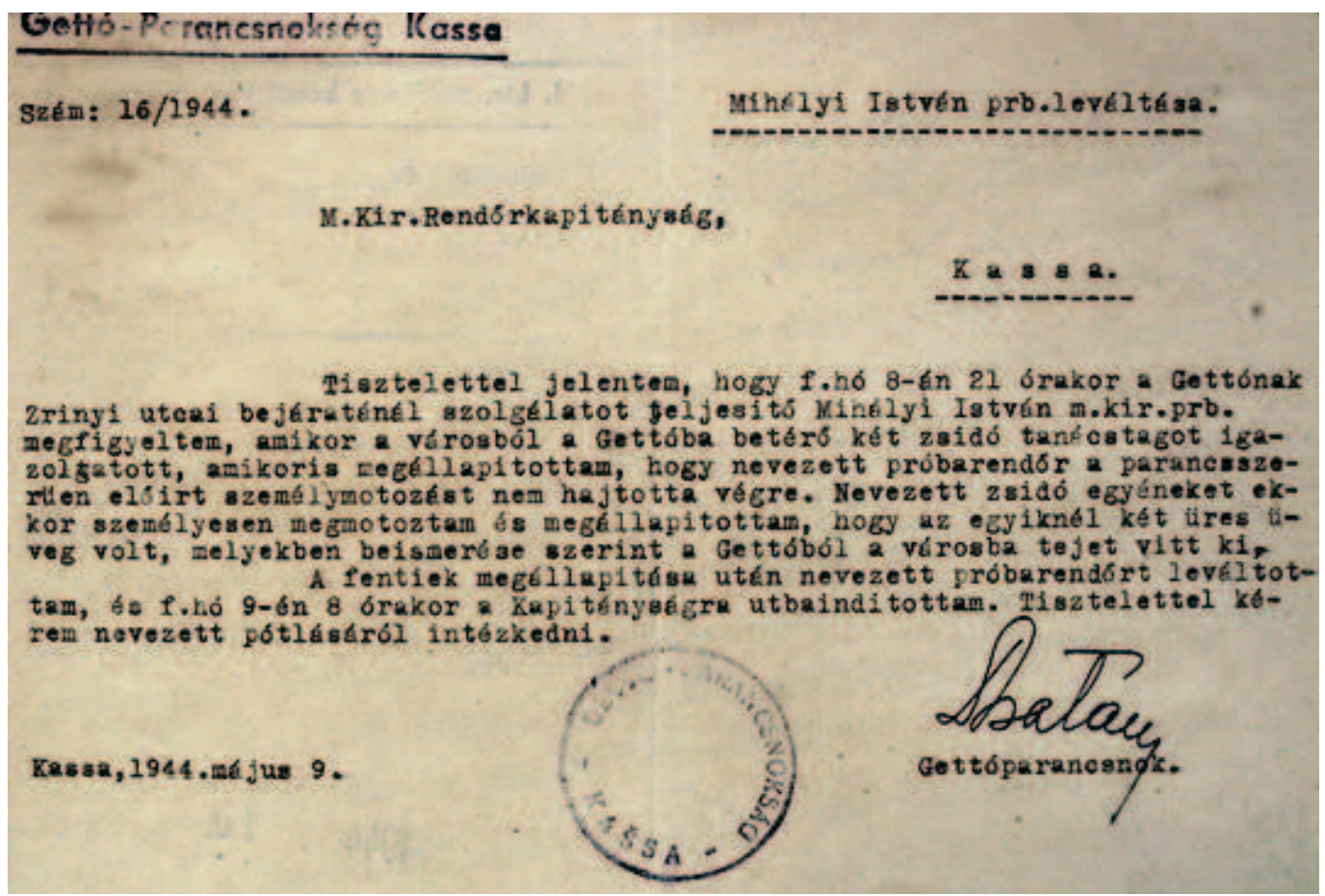

Megjegyzés:A két jelentés és a rajtuk látható egymástól merőben eltérő aláirások 1944. V. 5-én és 1944. V. 9-én készültek mindössze négy nap eltéréssel. Bemutatásuk a 2012. VII. 25-én a budapesti Holokauszt Emlékközpontban a dr. CSATÁRY László Lajossal kapcsolatos a Kassai Állami Levéltárban történt kutatás eredményéről tartott konferencián úgy, mint dr. CSATÁRY László Lajos gettóparancsnok által aláírt dokumentumok. A dokumentumok az ÁBTL internetes folyóirata a Betekintő 2014/3. számában a Csatári László és az 1944-es kassai deportálások címmel megjelent írásban is meghivatkozásra kerültek.

Forrás ! Kassa Állami Levéltára 17. d. 4728/1944. sz. akta és 18. d. 4814/1944. sz. akta 
A Rendörfelügyelöség beosztottjainak névsora

VII.sz. melléklet

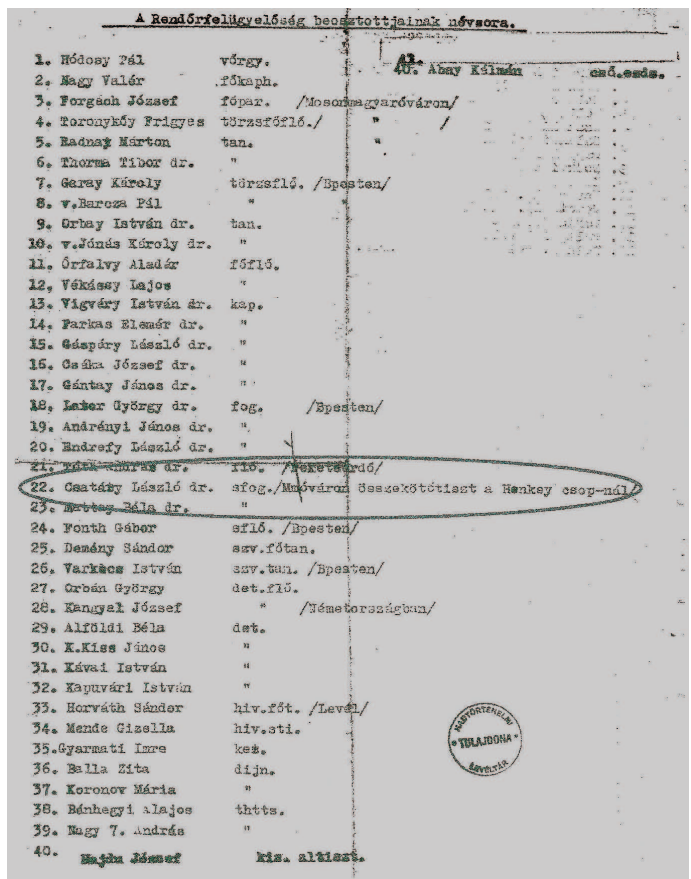

Megjegyzés: A dokumentum 1944 őszén készül a Magyar Királyi Rendőrség militarizálásának időszakában. A névsor azoknak a nevét sorolja fel, akik a HóDOsy Pál ny.á. csendőr vezérőrnagy vezetése alatt álló Rendörfelügyelőség munkatársai voltak. Dr. CSATÁRY László Lajos neve CSATÁRY László dr. megnevezéssel sfog. jelöléssel a 22-es sorszám mellett olvasható. A dokumentumot 2010 márciusában a II. kerületi Házmán utcában az egyik lakóház tetőterének felújítása során találta meg egy kőműves mester. Az épület 1945. II. 11-12.-i Budai várból történő kitörés útvonalán, a Pasaréten található.

Forrás ! HIM.HL. M.Kir. Rendőrség iratai, növekedési naplószám 52/2010. 1 p.

VIII.sz. melléklet

Kanadai Szövetségi Bíróság (The Federal Court of Canada) T 2399-96. számú „Ladislaus Csizsik-CSATARY” dosszié

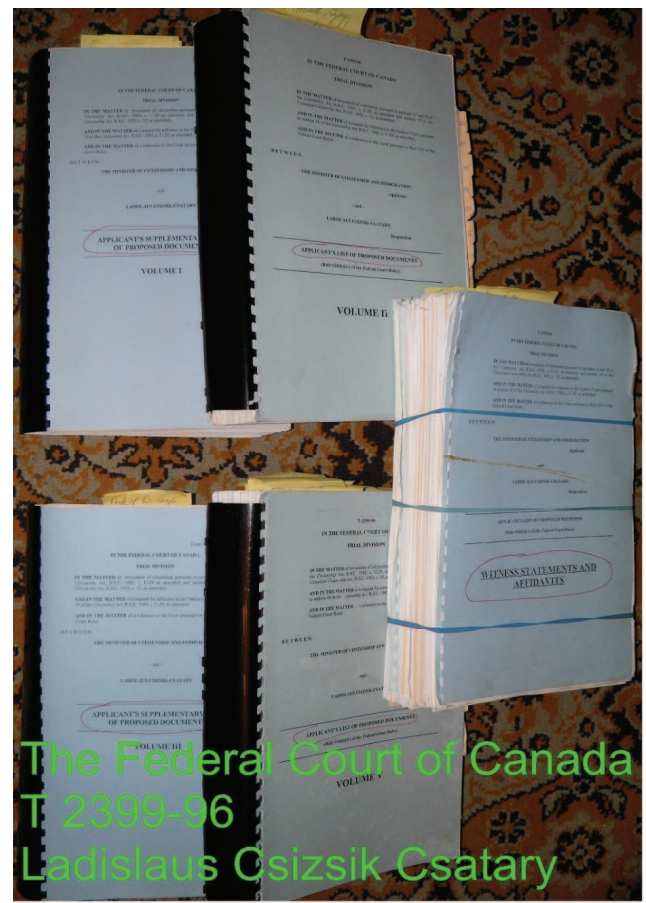

Megjegyzés: Az öt kötetből álló dosszié IV. kötete tartalmazza azokat a jegyzőkönyveket, amelyek a túlélő szemtanúk vallomásait tartalmazzák. A T 2399-96. számú dosszié tartalmának másolatát a Kanadai Szövetségi Bíróság (The Federal Court of Canada) adta át dr. CSATÁRY László Lajosnak a nyomozás lezárását követően.

Forrás ! CSLL.MI. T 2399-96. 
Fotó tabló a T 2399-96. számú felismertetési eljárásban
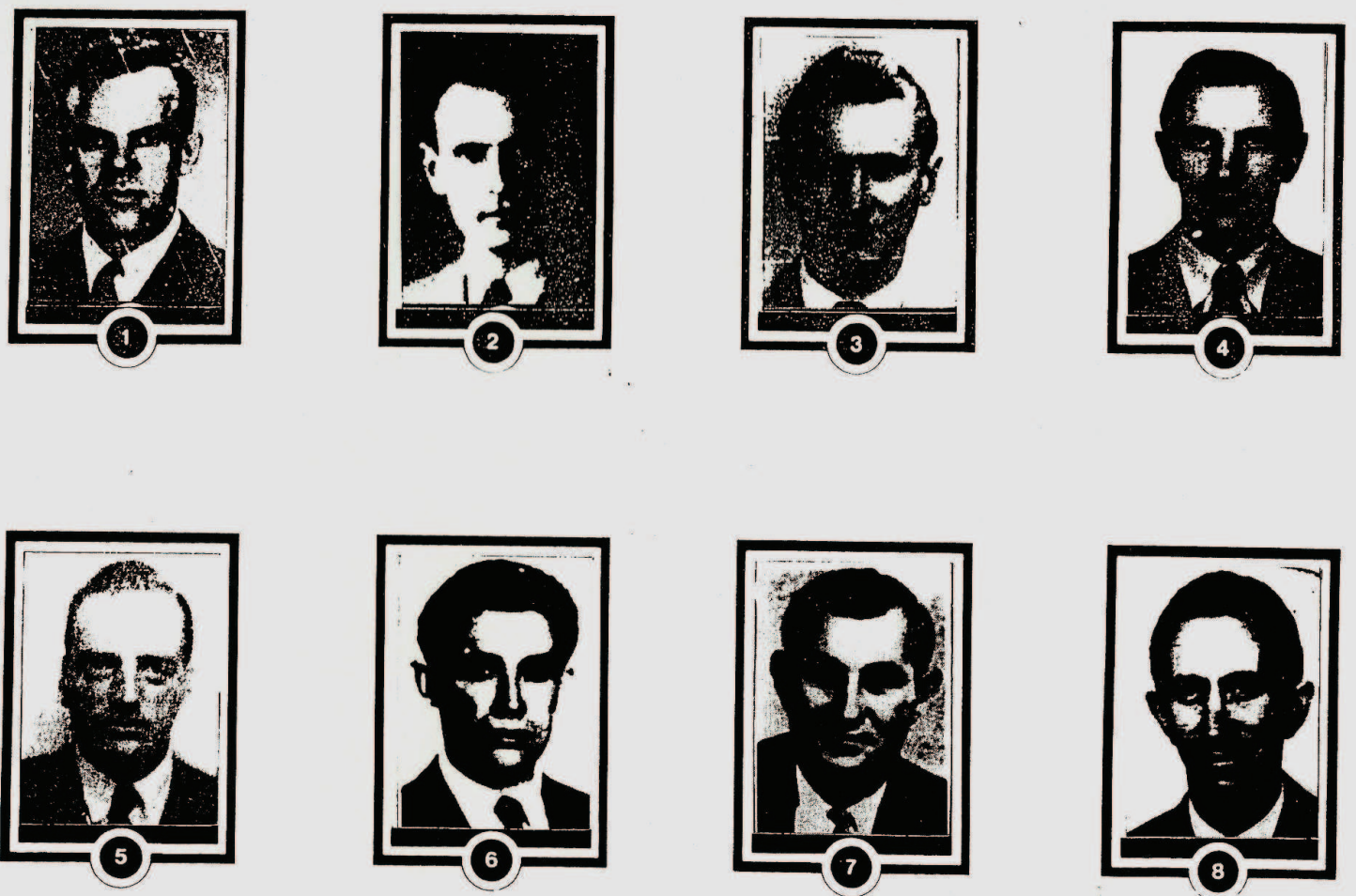

Megjegyzés: A fotótablókat, amelyek mindegyikén szerepel dr. CSATÁRY László Lajos fényképe, a Kanadai Királyi Szövetségi Rendőrség (Canadian Royal Mounted Police) állította össze a felismertetés eljárások elvégzéséhez lefolytatott nemzetközi nyomozás során.

Forrás ! CSLL.MI. T 2399-96.sz.

Susan KISS tanúkihallgatási jegyzőkönyvének részlete

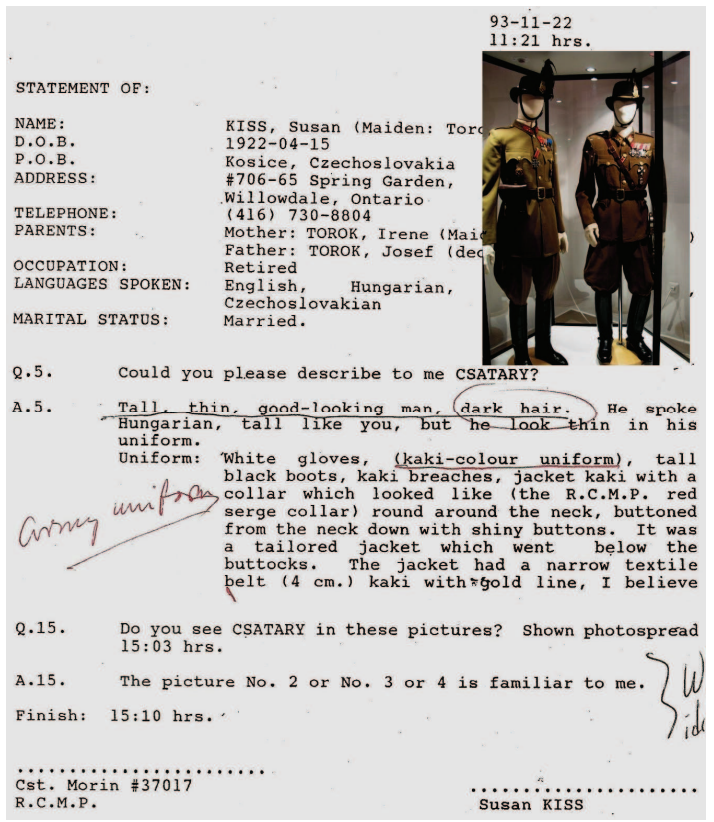

Megjegyzés: A tanú által adott leírás az általa dr. CsATÁRY László Lajosnak ismert személy ruházatáról, valamint a felismertetési eljárás során adott többvariációs bizonytalan személykiválasztásról. A kép jobb felső sarkában általam elhelyezett fotó a korabeli csendőr egyenruhákat mutatja azokat, amelyeket Susan KIss írt le vallomásában.

Forrás ! CSLL.MI. T 2399-96.sz.dosszié. 
Judy LYSY tanúkihallgatási jegyzőkönyvének részlete

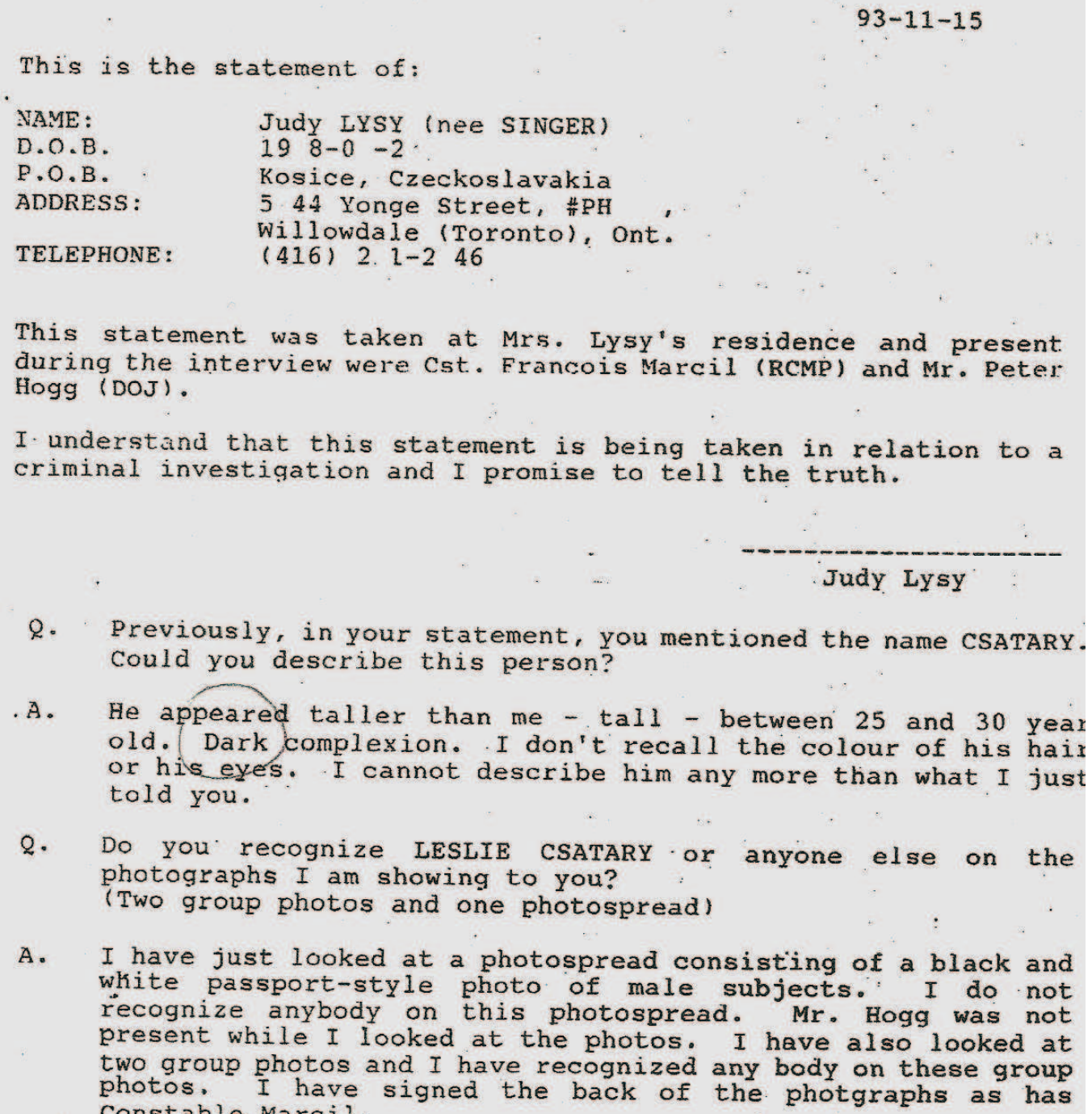

2. Previously, in your statement, you mentioned the name CSATARY. could you describe this person?

A. He appeared taller than me - tall - between 25 and 30 year old. Dark complexion. I don't recall the colour of his hais or his eyes. I cannot describe him any more than what I just told you.

Q. Do you recognize LESLIE CSATARY or anyone else on the photographs I am showing to you?

A. I have just looked at a photospread consisting of a black and white passport-style photo of male subjects." I do not recognize anybody on this photospread. Mr. Hogg was not present while I looked at the photos. I have also looked at two group photos and I have recognized any body on these group photos. I have signed the back of the photgraphs as has

Megjegyzés: Judy LYSY nem ismerte fel a tablón azt a személyt aki sérelmére a jogsértést 1944 tavaszán Kassán elkövette.

Forrás ! CSLL.MI. T 2399-96.sz.dosszié. 
Dr. Stefan KAIFER tanúkihallgatási jegyzökönyvének részlete.

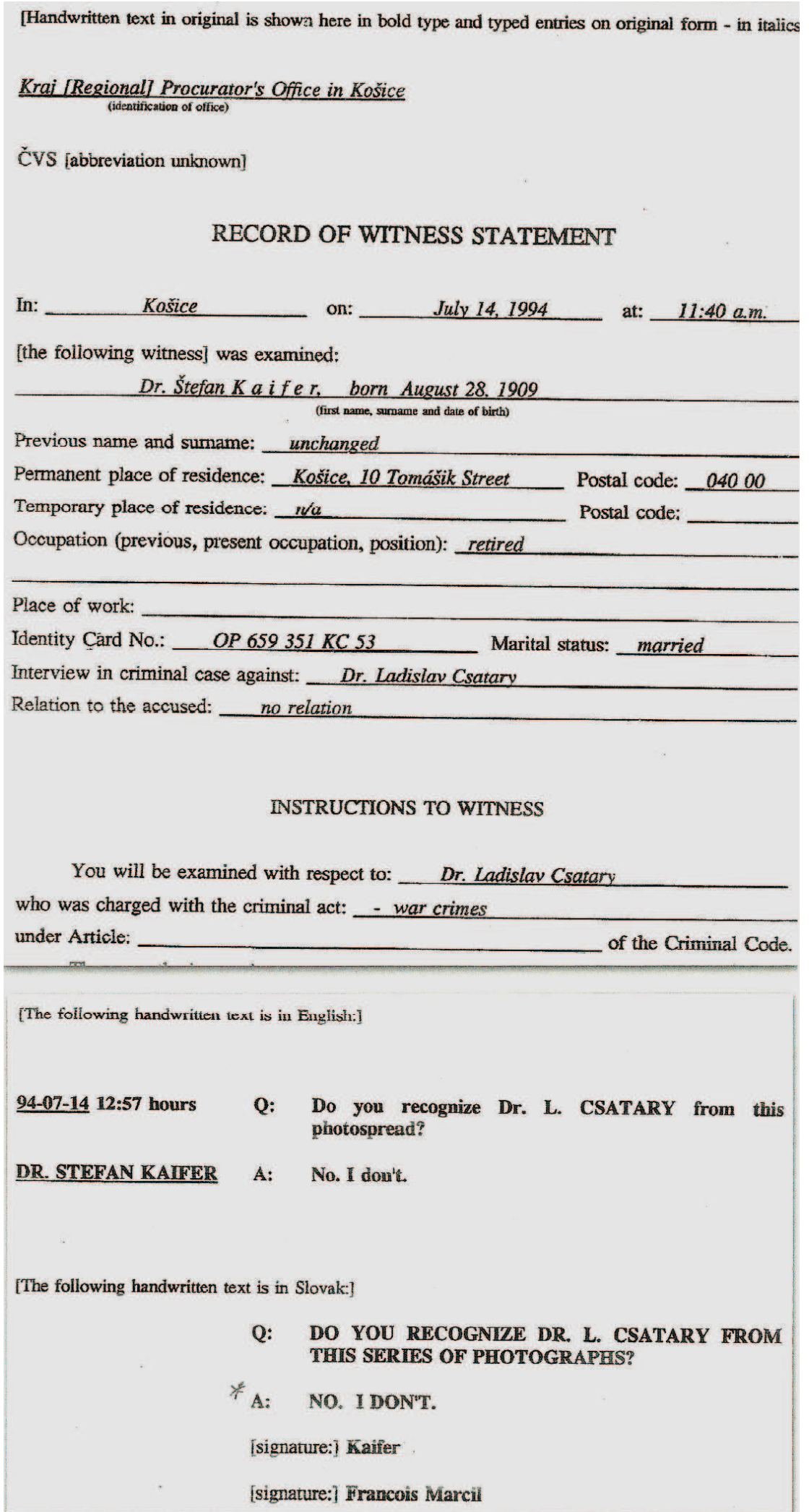

Megjegyzés: Dr. Stefan KAIFER nem tudta azonosítani dr. CsATÁRY László Lajost.

Forrás ! CSLL.MI. T 2399-96.sz.dosszié. 
STATEMENT OF :

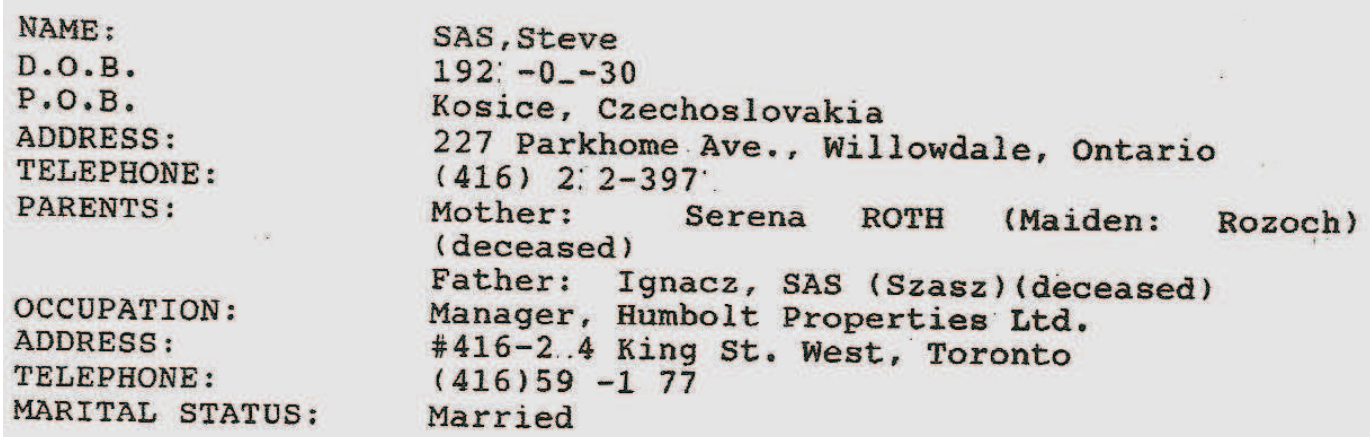

What language do you speak? English, Eungarian, Slovak, German, French, Spanish.

This statement is being taken at 214 king street West, suite 416 in Toronto, by Cst. C. Morin of the RCMP.

"I realize that this statement is taken in relation to a criminal investigation and I promise to tell you the truth."

signed.$\ldots \ldots \ldots \ldots \ldots \ldots \ldots \ldots \ldots \ldots \ldots$

Steve Sas

My family own a military supply store in the city and during the holidays, I use to help with the store 11940 to 1944), and I saw Csatary in the store on a regular basis. He was a good client. He was a nice person. I saw him several times. I knew his name. I don't recall if he told me, I only know, I knew who he was.

Cpuld you describe for me Mr. Csatary?

$10 \mathrm{~N}$

He was young, $180 \mathrm{~cm}$, 160-170 1bs.. healthy good-looking young chap, he had short dark hair. I don't recall the colour of his eyes. He had no distinguishing feature. He always wore a uniform as described before. He also wore a sabre with a big handle, and carried it on the left side. The sabre was inside a case and fitted on his police belt. I don't remember the description of the uniform but it was different from the policemen on the street which lead me to believe he was an officer. He might have had a white collar on his shirt and some insignia on the collar or shoulder. He wore black pants. He wore a special hat (Shaku)-black with gold trim. Shirt blue - had breast pockets. He usuallv walked. The first time I saw Csatary was in 1940 or 41 . He spoke Hungarian. I never heard him speak any other language. The times I saw him, I was fairly close $(2$ feet). I always saw him in uniform prior to, or inside the brick factory.

I never observed Csatary giving orders to other guards inside the brick factory. I only observed him walking, stopping and meeting guards (other police officers), speaking with them, then walking away.

Megjegyzés: SAS Steve által adott személyleírás egy sötét hajú, általa dr. CSATÁRY László Lajosnak ismert személyről, valamint vallomása arról, hogy már 1940, vagy 1941-ben találkozott vele Kassán, szülei boltjában.

Forrás ! CSLL.MI. T 2399-96.sz.dosszié. 
Georg Z. WASSERMANN tanúkihallgatási jegyzőkönyvének részlete.

94-03-29

09:00 hrs.

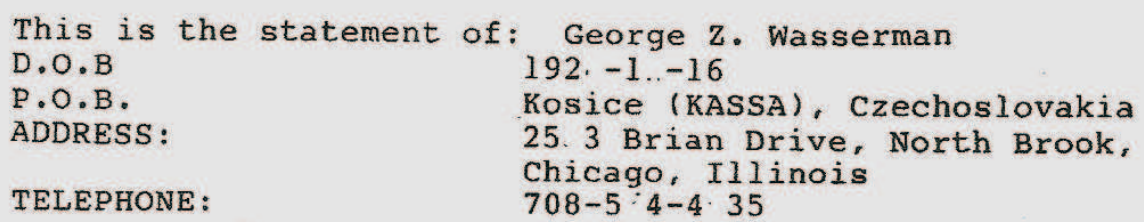

A. Not about him. I was interviewed about the concentration camps by someone from the German Consulate.

Q. Have you ever been shown photographs of people from world War II?

A. No.

Q. I will show you a photo line-up consisting of eight black and white passport-style photos, of eight male individuals. I ask you to take a look at it and tell me if you can recognize LESLIE CSATARY from this photo line-up?

A. I believe it is \#5.

Q. Would you be willing to testify in a court of law in canada should the subject of this investigation be charged?

A. Yes.

Q. Do you know of any other witnesses who are alive and could be able to help us in this investigation?

A. No.

Q. How is your health?

A. Good. No problem.

Time: $11: 10$

. $\ldots \ldots \ldots \ldots \ldots \ldots \ldots \ldots \ldots$

George WASSERMAN

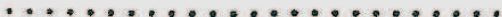

Francois MARCIL.

Megjegyzés: A tanú egy sötét hajú személyt ír le és úgy hiszi, hogy az ötödik számú fotó az, amely dr. CSATÁRY László Lajosról készült.

Forrás ! CSLL.MI. T 2399-96.sz.dosszié. 
Shachar YESHA'AYAHU fényképröl történö felismertetési jegyzőkönyve.

\section{Israel Police}

Statement by:

Statement no. folio no. 3

\begin{tabular}{|l|l|l|l|}
\hline LD. Number: & Given name: & $\begin{array}{l}\text { Surname: } \\
\text { Shachar }\end{array}$ & $\begin{array}{l}\text { Name in } \\
\text { romanization: } \\
\text { Yesha'ay; _u Shachar }\end{array}$ \\
\hline Former name: & $\begin{array}{l}\text { Marital status: } \\
\text { Married_Single__ } \\
\text { Divorced_Widowed_ _ }\end{array}$ & Sex: & Religion: \\
\hline Date of birth: & Place of birth: & $\begin{array}{l}\text { Home } \\
\text { telephone: }\end{array}$ & $\begin{array}{l}\text { Work } \\
\text { telephone: }\end{array}$ \\
\hline Address: & & Name and address of place of work: \\
\hline Personal no. in L.D.F.: & Father's name: & Parents' address: \\
\hline
\end{tabular}

Investigators:

\begin{tabular}{llll}
\hline Date & Time Place Pers. no. Rank Given Name Surname
\end{tabular}

X. It seems to me the that one of the persons, in photo 2 or 3 , is Csatary. I was Tiberated on 8 May 1945 by the Russians, in [Lower? - unclear - tr.] Silesia, not far from the Czech border, in Camp Cernau [?]. This moment I have remembered and I ask that it be added to what I have related up to now, that Csatary used to strike his boots with the whip which he held in his hand. This is my statement as I have given it, and I am confirming its truth with my hand and signature on every page.
[signatures] Yesha'ayahu Shachar
Miri Drucker
J.S. Rainville

940309

Megjegyzés: A tanú nem azonosította dr. CsATÁRY László Lajost.

Forrás ! CSLL.MI. T 2399-96.sz.dosszié. 
Igazolás a CSATÁRY-család lakcím bejelentkezésröl a németországi Simbach am Inn városába

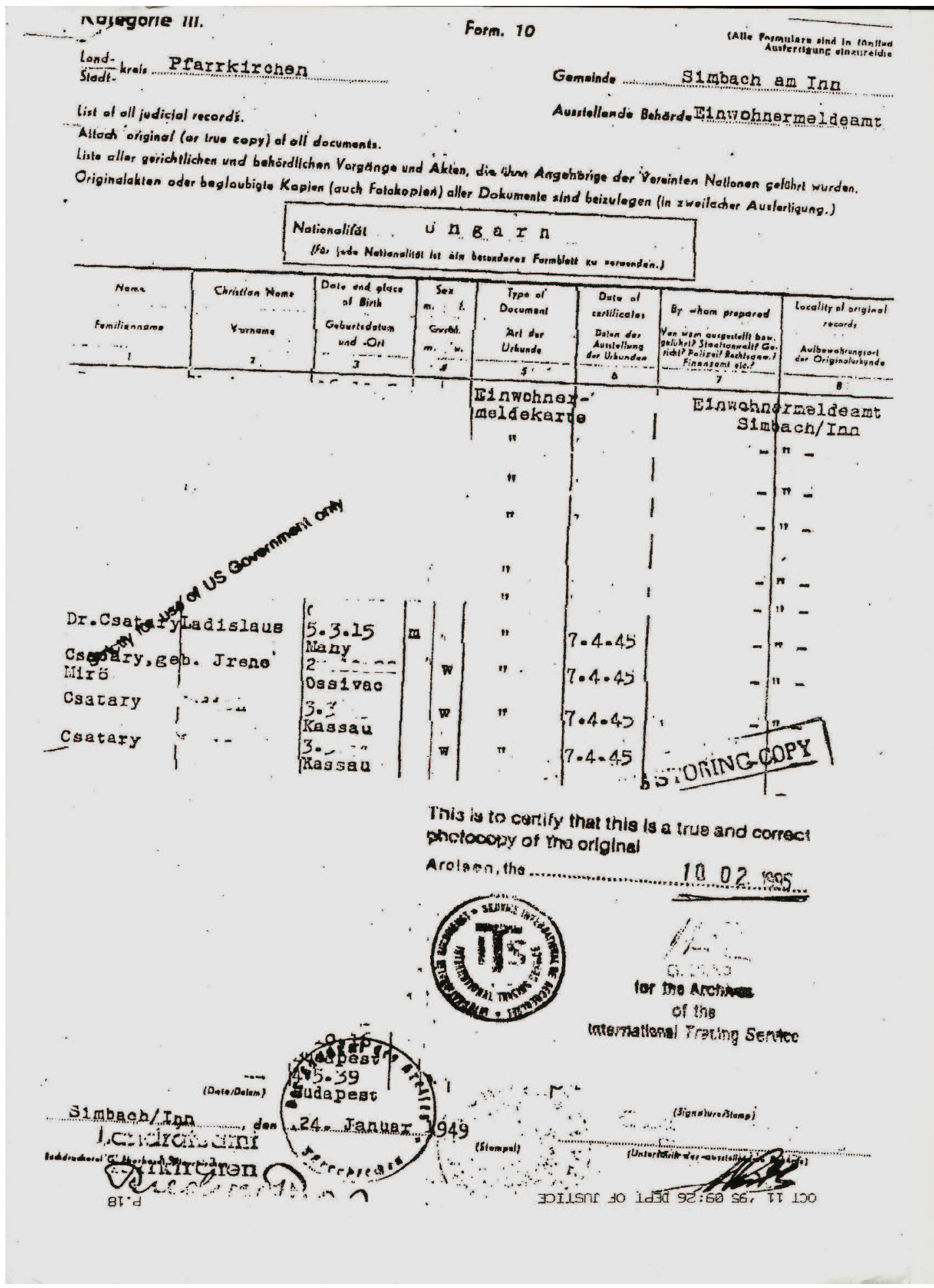

Megjegyzés: Az igazolás azt tanúsítja, hogy dr. CSATÁRY László Lajos családjával együtt 1945. IV. 7-én a németországi Simbach am Inn-ben már bejelentett lakos volt. Az igazolás a Kanadai Királyi Szövetségi Rendörség (Royal Canadian Mounted Police) eljárása során lett bekérve az Nemzetközi Nyomozó Szolgálat (International Tracing Service) archívumából.

Forrás ! FCCA. T 2399-96. 
Igazolás a németországi Simbach am Inn városi Magyar iroda vezetőjétöl

\section{Masyar Iroda Siribrch/Tmm.}

\section{G A Z O I VA N Y.}

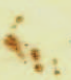

A7ulirott, a Simbach/Imn-1 / : Baycrn_Némotország:fi liagyar Iroda vezetője hivatalosan igazolja, hogy Dr. C S I Z S I K - C S A T A R Y IÁszlo vr aki született 19,55 évi március hó 5-én Hány közságben /:Magyaronszág:/ anyja neve:Pittkó Margit, volt Simbach/Inn-1 /:Bayern, Németorsłzág:/ lakosnak Mapyar-

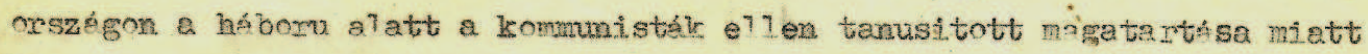
1946 év végén a kommunista mgyar kormány Németországból való kiadatúsát kérte. A kommunista nagyar kornény ezen kémb́st az 17letékes anerikai katonai ham tóstigok elutasitottak. Uryanis az amerilrai katonai hatóst́gok egyöntetilen meg-

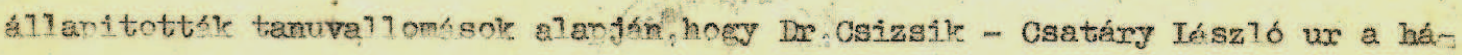
boru alatt denokratikus módon folybatta politikai harcát a kommunisták ellen . Simbech/Inn, 1949 ávi május hó 6-án.
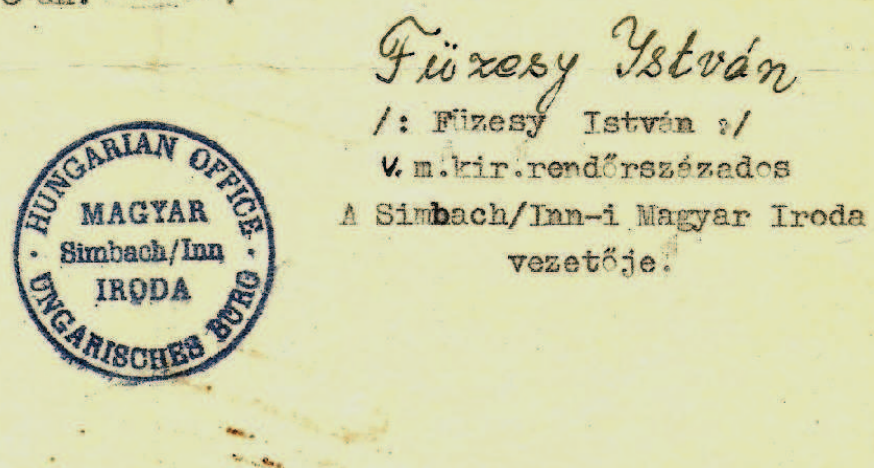

Megjegyzés: Az igazolást FÜZESY István rendőr százados állította ki dr. CSATÁRY László Lajos számára, amely szerint az USA katonai hatóságai lenyomozták háború alatt tanúsított viselkedését és azt állapították meg, hogy feladatát demokratikus módon végezte.

Forrás ! CSLL.MI. 
A kassai népbíróság dr. CSATÁRY László Lajos ellen kiadott elfogató parancsa.

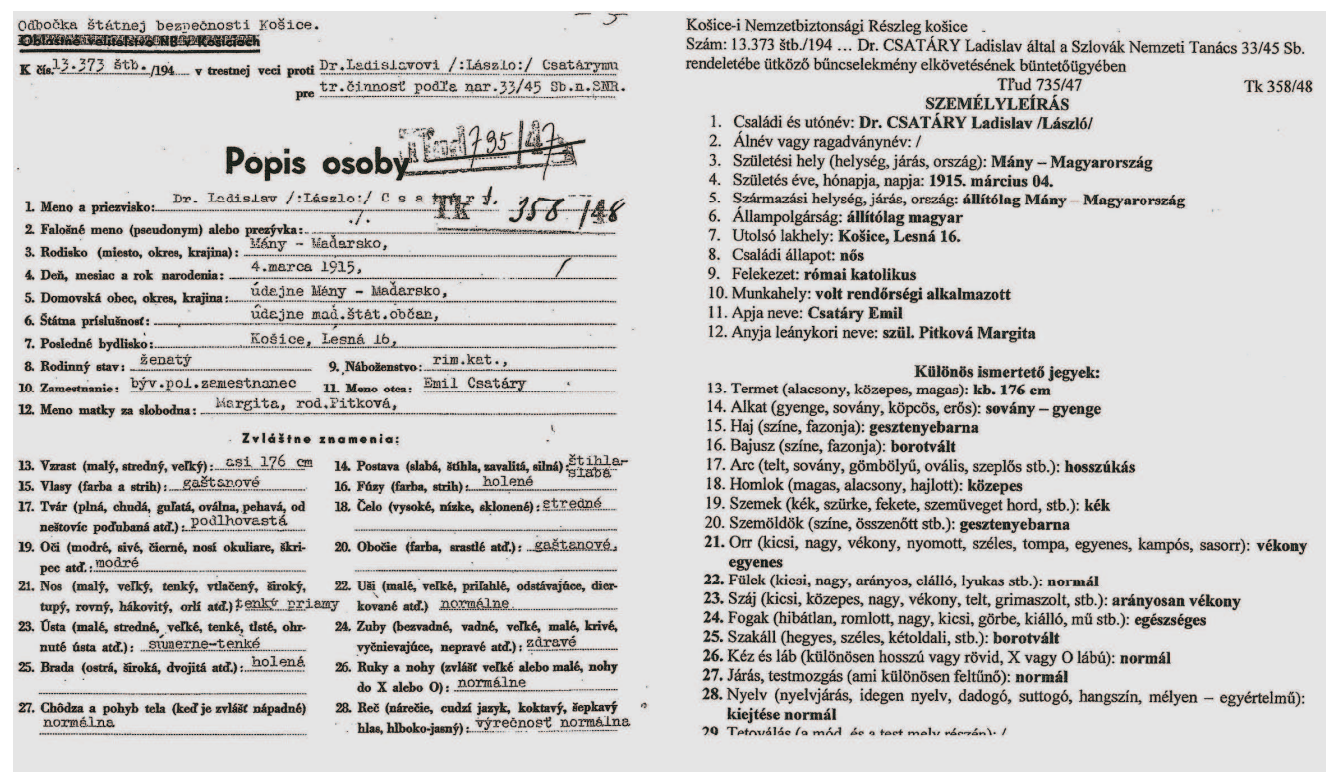

Megjegyzés: A szlovák nyelvü elfogatóparancs tartalmazza a dr. CsATÁRY László Lajosnak tulajdonított személyleírást. A szlovák nyelvü elfogatóparancs és annak magyar nyelvre lefordított szövege a jobb érthetőség miatt lett a fotón egymás mellé szerkesztve. Az eredeti szlovák nyelvú irat magyar nyelvre történő hiteles lefordítása a dr. CsATÁRY László Lajos ellen Budapesten a Budapesti Nyomozó Ügyészség nyomozása során történt.

Forrás ! KAL. Tk 358/1948.sz. ； BNYÜ.I. nyom. 1597/2011.

XIX.sz. melléklet

Dr. CSATÁRY László Lajos számára Kassán 1943-ban kiállított útlevél 1. és 2. oldala.

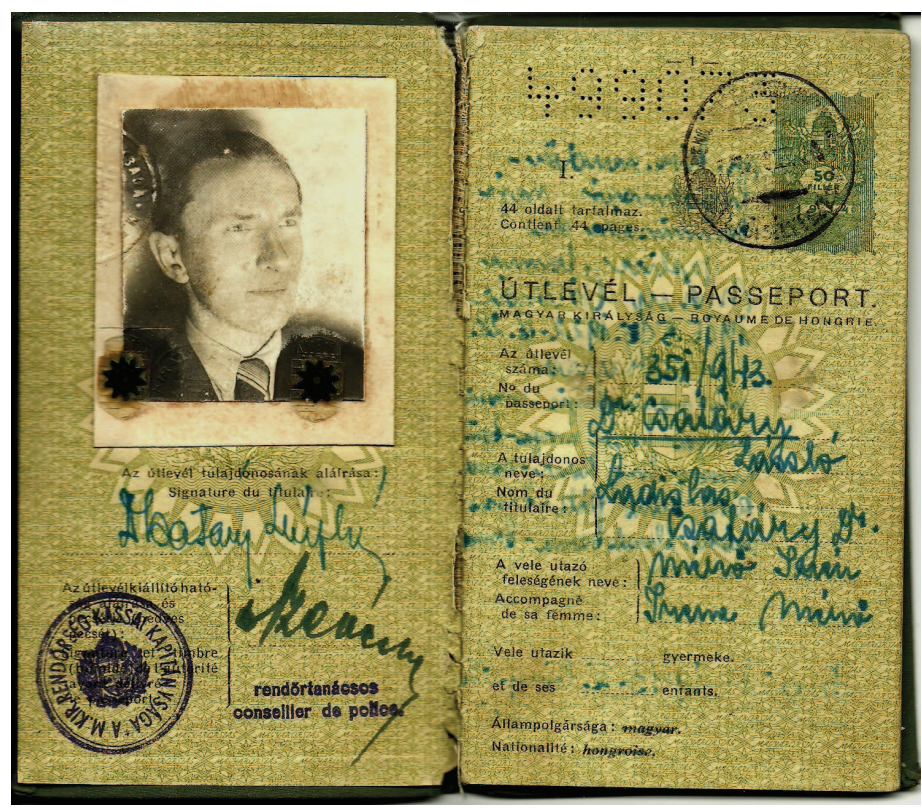

Forrás ! CSLL.MI. op.cit. 499073. számú útlevél 1. és 2. oldala. 


\section{Dr. CSATÁRY László Lajos Kassán 1943-ban kiállított útlevele (3-4. oldal)}

XX.sz. melléklet

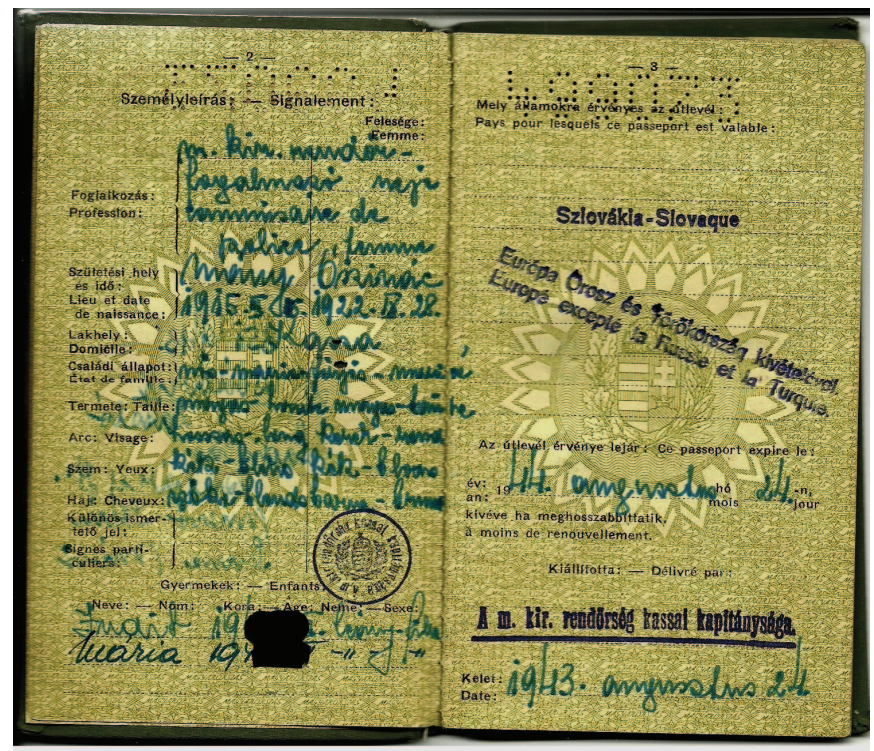

Megjegyzés: A 499073. számú útlevél 3-4. oldala dr. CsATÁRY László Lajos adataival és személyleírásával. Az útlevél különös jellegzetessége, hogy párhuzamosan tartalmazza felesége adatait és személyleírását. Forrás ! CSLL.MI. op.cit. 499073. számú útlevél 3. és 4. oldala.

\section{Dr. CSATÁRY László Lajos 1948-ban Münchenben kiállított német személyi igazolványa}

$$
\text { XXI.sz. melléklet }
$$

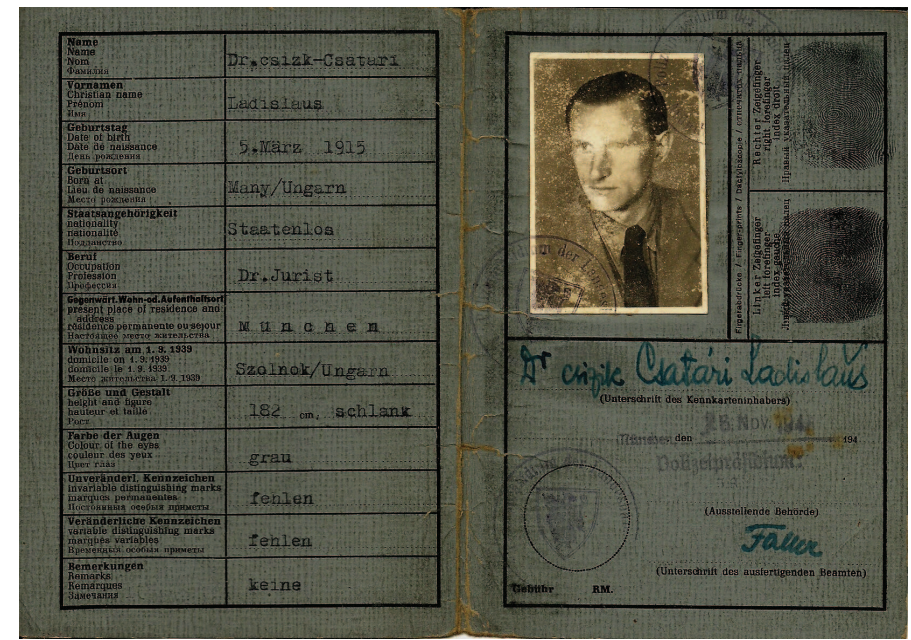

Megjegyzés: „Dr. csizsik Csatári Ladislaus” számára 1948-ban Münchenben kiállított személyi igazolvány, amiben a személyleírása mellett ujjnyomata is szerepelt.

Forrás ! CSLL.MI. op.cit. B.XXVI/23453 számú személyi igazolvány.

A Magyar Királyi Rendőrség fogalmazói karba történö alkalmazás kellékei

\section{A fogalmazói és felïgyelöi karban való alkalmazás kel-} lékei:"

1. 21 évet meghaladó, de 30 éven aluli életkor,

2. nötlen áliaput,

3. erôs testalkat és egészséges szervezet,

4. a fogalmazói karhoz pályázóknál az 1929 :

Forrás ! A rendőrség szervezete és ügyvitele. op.cit. 76-77.p. Budapest, 1943, Magyar Királyi Belügyminisztérium. $200 \mathrm{p}$. 


\section{Dr. CSATÁRY László Lajos rendör segédfogalmazóról készült korabeli fényképek}

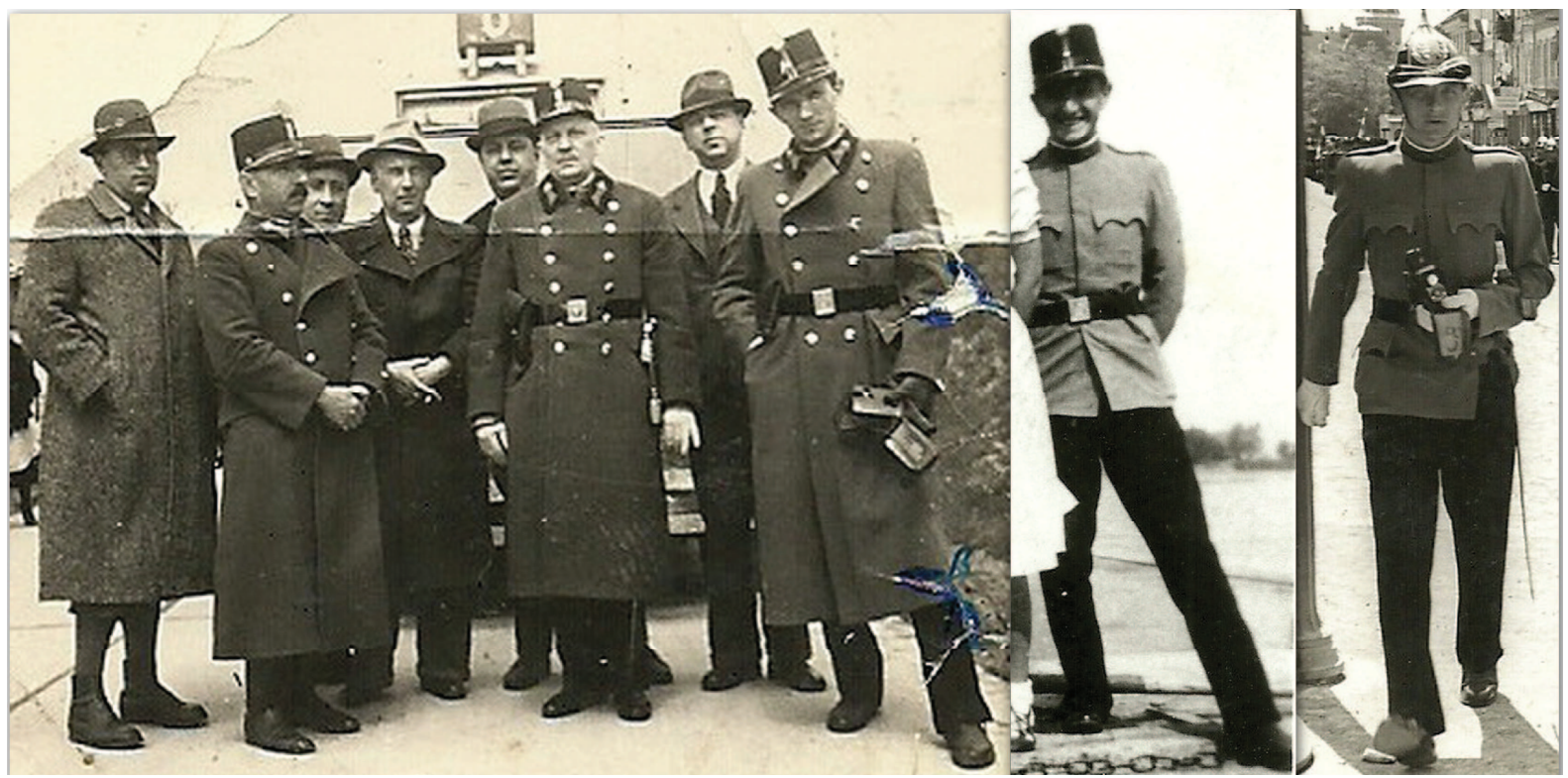

Megjegyzés: A kép-montázs dr. CSATÁRY László Lajos magándokumentumaiból van összeállítva. Dr. CSATÁRY László Lajosról fennmaradt fotók, amelyeken rendőrségi formaruhában látható. A felvételeken jól látható az erős testalkat, valamint az, hogy termete kimagaslott a többi rendőr között, ami alátámasztja $182 \mathrm{~cm}$-es testmagasságát. A kép, három fotó felhasználásával készített montázs. Dr. CSATÁRY László Lajos a jobb oldalon látható.

Forrás ! CSLL.MI.

A Kanadai Igazságügyi Minisztérium 2015. IV.13-án kelt levele

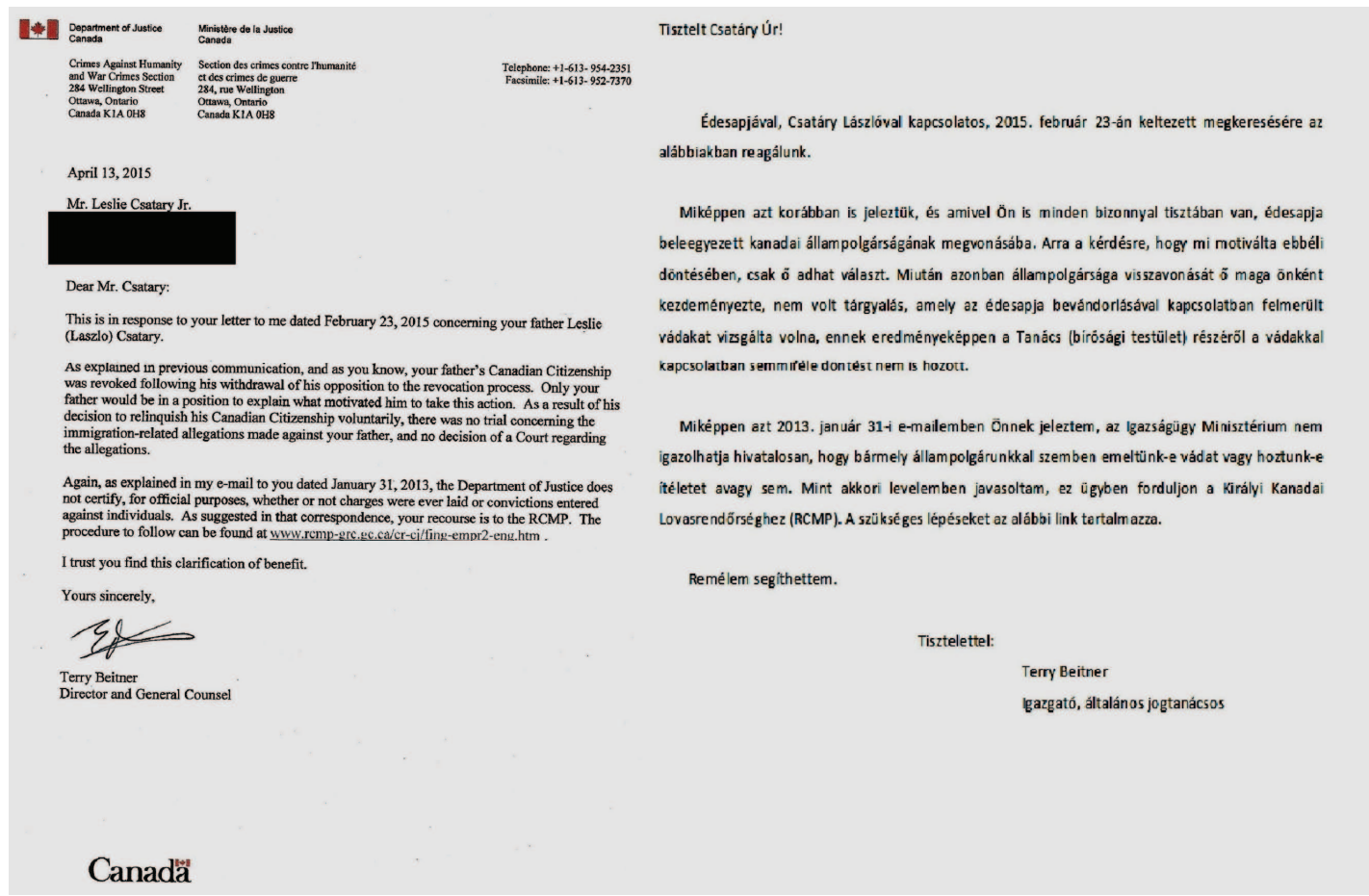

Megjegyzés: A Kanadai Igazságügyi Minisztérium arról ad tájékoztatást, hogy nem tudják mi motiválta dr. CSATÁRY László Lajost kanadai állampolgárságáról való lemondásában, továbbá arról, hogy 1949-ben Kanadába történő bevándorlásával kapcsolatban semmiféle vádakat nem vizsgáltak és ebben bírói döntés nem történt. A fotó montázsban az eredeti angol nyelvü levél mellett, a magyar nyelvü olvasható.

Forrás ! CSLL.MI. 